\title{
MENJADI WIDYAISWARA PEMBELAJAR
}

\author{
Neneng Maria Kiptyah
}

Nizamia Learning Center 


\section{MENJADI WIDYAISWARA PEMBELAJAR}

(C) Neneng Maria Kiptyah, M.Pd.

Anggota IKAPI

Register 166/JTI/2016

All right reserved

\section{Penulis:}

Neneng Maria Kiptyah, M.Pd.

\section{Layout:}

Rizki Janata

Diterbitkan pertama kali oleh

Nizamia Learning Center

Ruko Valencia AA-15 Sidoarjo

Telepon (031) 8913874

E-mail: nizamiacenter@gmail.com

Website: www.nizamiacenter.com

Cetakan pertama, Mei 2020

$\mathrm{vi}+148 \mathrm{hlm}$.; $16 \mathrm{~cm}$ x $24 \mathrm{~cm}$

ISBN 978-623-265-090-9 


\title{
SAMBUTAN
}

\author{
Dr. M. Musfiqon, M.Pd. \\ (Widyaiswara Balai Diklat Keagamaan Surabaya)
}

\section{Assalamualaikum wa rahmatullah wa barakatuh}

Alhamdulillahi rabbil 'alamiin, puji syukur kami panjatkan ke hadirat Allah SWT, karena atas segala rahmat dan hidayah-Nya, hati yang senantiasa merindukan cinta dan kasih-Nya dapat menggoreskan tinta di atas lembar putih dengan keadaan sehat tiada kurang apapun. Perasaan rindu dan bahagia mengiringi untaian sholawat kepada junjungan dan panutan kita, Nabi Muhammad SAW. Dengan segala nikmat yang telah Allah berikan, buku dengan judul Menjadi Widyaiswara Pembelajar telah selesai disusun oleh Neneng Maria Kiptyah, M.Pd. Dengan penyusunan buku ini diharapkan agar dapat menjadi sumber wawasan baru bagi setiap pembaca khususnya para widyaiswara dalam membentuk semangat dan paradigma pendidikan dan pelatihan di zaman modern seperti sekarang.

Sebagaimana yang telah kita ketahui bersama, widyaiswara berperan dalam memberikan pelayanan dalam pendidikan dan pelatihan. Di sana terdapat sebuah teori mengenai Building Service Commitment (BSC). Ini merupakan satu kegiatan dalam sebuah Pendidikan dan Pelatihan (diklat) yang bertujuan untuk membangun komitmen belajar bersama yang bermuara pada pelayanan yang diselaraskan dalam setiap instansi pemerintah. Membangun komitmen pelayanan di era milenial ini diperlukan semacam rumusan yang terkoordinasi dan terpadu, sehingga ada beberapa istilah tentang pelayanan ini yang kita temukan diberbagai wilayah di Indonesia seperti: pelayanan satu pintu, pelayanan satu atap, pelayanan terpadu, pelayanan prima dan lain sebagainya. Untuk 
mewujudkan bentuk pelayanan seperti itu diperlukan komitmen dan juga kompetensi dari widyaiswara.

Terlebih lagi, widyaiswara di zaman sekarang harus meningkatkan semangat belajarnya dan terus berkarya, tidak hanya sekedar mengajar di dalam tanpa menghasilkan karya yang bermanfaaat untuk orang banyak. Berbagai karya yang kreatif dan inovatif harus mulai dikembangkan oleh guru dalam berbagai bidang pendidikan. Melalui buku ini, Neneng Maria Kiptyah, M.Pd. telah mampu menghasilkan karya dalam bidang literasi, membagikan berbagai pemikiran positif, wawasan, dan motivasi terkait khazanah pendidikan di zaman sekarang.

Akhir kata, semoga karya ini mampu menjadi umpan semangat dan minat para pendidik terutama widyaiswara di seluruh Indonesia agar mengembangkan kembali pendidikan dan pelatihan di era sekarang ini, diantaranya melalui karya-karya positif yang dapat menginspirasi banyak orang.

Wassalamu'alaikum wa rahmatullah wa barakatuh

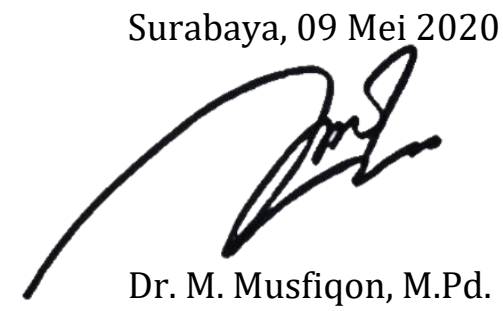




\section{KATA PENGANTAR}

Alhamdulillahi rabbil 'alamiin, penulis telah selesai menyusun buku dengan judul Menjadi Widyaiswara Pembelajar. Buku ini di susun dengan harapan agar dapat menjadi referensi bagi setiap widyaiswara pada khususnya dan ASN pada umumnya.

Seorang widyaiswara dituntut untuk terus mengembangkan kapasitas dirinya terutama terkait dalam kegiatan ilmiah dan selalu update informasi. Kesempatan telah dibuka lebar sesuai aturan regulasi dan kini hanya menunggu action dari widyaiswara untuk menangkap kesempatan ini. Tuntutan regulasi dan masyarakat terhadap kinerja ASN seyogyanya menggugah widyaiswara untuk terus belajar, belajar dan belajar lagi.

Jika ingin mewujudkan ASN berkelas dunia maka widyaiswara pun harus berkelas dunia dan setidaknya harus memiliki paradigma terhadap lima kriteria kinerja ASN yakni: profesional, integritas, orientasi kepublikan, budaya pelayanan yang tinggi, serta memiliki wawasan global. Kelima kriteria tersebut perlu dilakukan oleh widyaiswara secara berkesinambungan guna memenuhi tuntutan kualifikasi widyaiswara yang mumpuni untuk mewujudkan ASN yang berkelas dunia tahun 2025.

Penulis menyadari, bahwa penyusunan buku ini masih terdapat kekurangan. Kritik dan saran tetap diperlukan untuk penyempurnaan buku ini di masa yang akan datang.

Jakarta, 06 Mei 2020

Penulis 


\section{DAFTAR ISI}

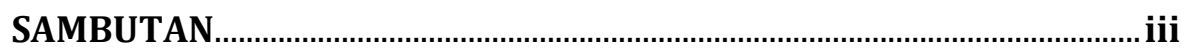

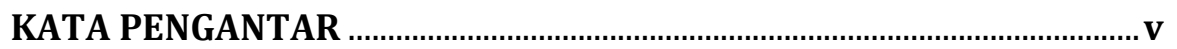

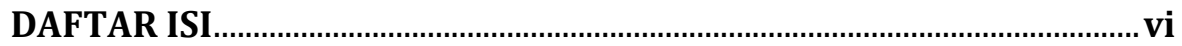

Halaman

BAGIAN I : MENJADI WIDYAISWARA PEMBELAJAR

BAGIAN II : PERSEPSI PESERTA DIKLAT TERHADAP URGENSI BAHASA INGGRIS DALAM 8 OPTIMALISASI KINERJA

BAGIAN III : PENINGKATAN KUALITAS TENAGA KEDIKLATAN DAN AKREDITASI LEMBAGA $\mathbf{3 4}$ DIKLAT

BAGIAN IV : URGENSI INTEGRITAS DALAM PELAKSANAAN TUGAS

BAGIAN V : LIVING IN HARMONY BY IMPLEMENTING MODERATION IN RELIGIOUS LIFE

BAGIAN VI : MANAJEMEN DIRI DAN PENINGKATAN KINERJA APARATUR SIPIL NEGARA KEMENTERIAN AGAMA

BAGIAN VII : TANGGUNG JAWAB DAN AMANAH DALAM BEKERJA

BAGIAN : SHORT COURSE NUEPA NEW DELHI

VIII

BAGIAN IX : PESONA WARISAN KEJAYAAN ISLAM DI INDIA 


\section{BAGIAN I}

\section{MENJADI WIDYAISWARA PEMBELAJAR}

Apa sih widyaiswara itu? Jujur, pertanyaan tersebut muncul saat penulis melihat selebaran informasi pendaftaran Calon Pegawai Negeri Sipil yang ditempel di kantor Kecamatan saat sedang mengurus kartu kuning untuk para pencari pekerjaan tahun 2004 lalu. Dan kini setelah mengalami beberapa proses bertahun-tahun, akhirnya penulis dengan penuh rasa syukur dan bangga menyandang jabatan sebagai seorang widyaiswara, salah satu jenis tenaga kediklatan dalam dunia pendidikan dan pelatihan (diklat). Jabatan yang identik dengan predikat "sang maha guru" ternyata menyimpan sejuta rasa, sejuta makna, sejuta tantangan, serta sejuta pengalaman berharga yang menurut penulis sangat "life changing experience."

Tenaga kediklatan yang merupakan bagian dari sumberdaya manusia aparatur menjadi salah satu bidang pembangunan yang menjadi perhatian pemerintah. Di tangan tenaga kediklatan akan bermunculan birokratbirokrat yang diperlukan dalam pembangunan. Apalagi di era reformasi birokrasi yang memerlukan birokrat-birokrat yang berpikir inovatif, berani 
melakukan terobosan positif untuk perbaikan dan memiliki visi untuk memberikan pelayanan terbaik bagi masyarakat. Untuk itu diperlukan berbagai diklat yang berkualitas yang dapat memfasilitasi pengembangan sumber daya aparatur pemerintah yang dapat membentuk birokrat seperti yang diharapkan di atas. Untuk menjamin terlaksananya pelaksanaan diklat yang berkualitas tersebut, diperlukan pengelolaan diklat yang berkualitas juga. Di sinilah diperlukan peran penting tenaga kediklatan yang salah satunya adalah widyaiswara sebagai seorang Aparatur Sipil Negara (ASN). Regulasi yang mengatur tentang pengembangan kompetensi ASN ini tertuang dalam UU ASN Nomor 5 Tahun 2014 dan Peraturan Pemerintah Nomor 11 Tahun 2017 tentang Manajemen PNS, sedangkan yang terkait langsung dengan widyaiswara terdapat di dalam Peraturan Menteri Pendayagunaan Aparatur Negara dan RB Nomor 22 Tahun 2014 tentang Jabatan Fungsional Widyaiswara dan Angka Kreditnya.

Di dalam UU ASN dijelaskan tentang Hak dan Kesempatan bagi ASN baik Pegawai Negeri Sipil (PNS) maupun Pegawai Pemerintah dengan Perjanjian Kerja (PPPK) mengikuti pengembangan kompetensi, yaitu 1) Memiliki hak dan kesempatan yang sama untuk diikutsertakan dalam pengembangan kompetensi, dengan memperhatikan hasil penilaian kinerja dan penilaian kompetensi yang bersangkutan, 2) Pengembangan kompetensi sebagaimana dimaksud dilakukan paling kurang 80 jam pelajaran dalam 1 (satu) tahun.

Setiap ASN termasuk widyaiswara, memiliki hak dan kesempatan untuk mengembangkan kompetensi antara lain melalui: pendidikan dan pelatihan, seminar, kursus, dan penataran. Pengembangan kompetensi ini harus dievaluasi oleh pejabat yang berwenang dan digunakan sebagai salah satu dasar dalam pengangkatan jabatan dan pengembangan karier. Selain 
itu pengembangan kompetensi ini wajib disusun dalam rencana pengembangan kompetensi tahunan dalam rencana kerja anggaran tahunan instansi.

Jenis pengembangan dapat dilaksanakan melalui: 1) Pendidikan Formal yang terdiri dari a) Pengembangan kompetensi dalam bentuk pendidikan dilakukan untuk meningkatkan pengetahuan dan keahlian PNS melalui pendidikan formal sesuai dengan peraturan perundang-undangan, b) Pengembangan kompetensi dalam bentuk pendidikan formal sebagaimana dimaksud di atas dilaksanakan dengan pemberian tugas belajar. Pemberian tugas belajar sebagaimana dimaksud diberikan dalam rangka memenuhi kebutuhan standar kompetensi jabatan dan pengembangan karir.

Untuk tenaga kediklatan, yang terdiri dari pimpinan penyelenggara diklat, penyelenggara diklat dan widyaiswara maka harus dimotivasi untuk dapat melanjutkan pendidikan formal setidaknya ke tingkat strata dua mengingat tantangan dan tuntutan publik ke depan yang akan lebih berat. Terkait dengan widyaiswara, untuk pendidikan formal diharapkan sudah memasuki jenjang strata tiga, karena peserta diklat yang dihadapi akan lebih banyak yang berusia muda dan berwawasan luas, bahkan berpengalaman baik dalam dunia kerja.

Sedangkan yang berikutnya yaitu melalui 2) Pelatihan yang terdiri dari a) Pengembangan kompetensi dalam bentuk pelatihan dilakukan melalui jalur pelatihan klasikal dan non-klasikal, b) Pengembangan kompetensi dalam bentuk pelatihan klasikal sebagaimana dimaksud, dilakukan melalui proses pembelajaran tatap muka di dalam kelas, melalui pelatihan, seminar, kursus, penataran, sosialisasi, workshop, semiloka, sekolah kader serta bentuk lain yang sejenis. c) Pengembangan kompetensi dalam bentuk 
pelatihan non-klasikal sebagaimana dimaksud dilakukan melalui e-learning, bimbingan di tempat kerja, pelatihan jarak jauh, magang dan pertukaran antara PNS dan pegawai swasta serta bentuk lain yang sejenis.

Untuk tenaga kediklatan maka diharapkan sudah mengikuti berbagai pelatihan teknis yang dapat meningkatkan keterampilan mereka. Para pengelola diklat yang memegang kebijakan dalam pengelolaan diklat diharapkan telah mengikuti Diklat Teknis Pengelolaan Diklat (Management of Training/MOT), sedangkan para penyelenggara diklat yang bertugas menjadi panitia penyelenggara diharapkan telah mengikuti Diklat Teknis bagi Penyelenggara Diklat (Training Officer Course/TOC). Bagi widyaiswara harus mengikuti sejumlah Training of Trainers (TOT) demi meningkatkan kompetensi mendidik, mengajar dan melatih (dikjartih).

Dalam Peraturan Kepala Lembaga Administrasi Negara Nomor 25 tahun 2015 tentang Pedoman Akreditasi Lembaga Pendidikan dan Pelatihan Pemerintah disebutkan beberapa kriteria penilaian terhadap tenaga kediklatan saat terjadi proses akreditasi. Widyaiswara termasuk ke dalam salah satu tenaga kediklatan yang mendukung penilaian untuk akreditasi ini.

Penilaian terhadap widyaiswara atau tenaga pengajar meliputi: 1) Pendidikan formal, kompetensi, spesialisasi, pengalaman mengajar dan kesinambungan pengembangan bidang keahlian pada Diklat prajabatan dan/atau Diklat kepemimpinan tertentu, 2) Penilaian terhadap pendidikan formal adalah kesesuaian pendidikan formal widyaiswara atau tenaga pengajar dengan mata diklat yang diampu pada Diklat Prajabatan dan/atau Diklat Kepemimpinan tertentu; 3) Penilaian kompetensi widyaiswara atau tenaga pengajar adalah jumlah widyaiswara yang telah mengikuti Training of Trainers (TOT) dengan dibuktikan melalui 
sertifikat; 4) Penilaian terhadap spesialisasi adalah relevansi bidang spesialisasi Widyaiswara atau tenaga pengajar dengan mata diklat yang diampu pada Diklat Prajabatan dan/atau Diklat Kepemimpinan tertentu; 5) Penilaian terhadap pengalaman mengajar adalah tingkat frekuensi mengajarkan mata diklat yang diampu pada Diklat Prajabatan dan/atau Diklat Kepemimpinan tertentu; 6) Penilaian terhadap kesinambungan pengembangan bidang keahlian adalah program pengembangan kompetensi yang dimiliki atau dilaksanakan oleh widyaiswara atau tenaga pengajar sesuai dengan mata diklat yang diampu.

Dalam Peraturan Menteri Pendayagunaan Aparatur Negara dan Reformasi Birokrasi Nomor 22 Tahun 2014 tentang Jabatan Fungsional Widyaiswara dan Angka Kreditnya dijelaskan tentang hal-hal terkait widyaiswara sebagai berikut: 1) Tujuan Kebijakan Pembinaan Widyaiswara antara lain: a). Diarahkan untuk meningkatkan profesionalisme Widyaiswara, b). Revisi kebijakan sesuai kebutuhan tuntutan dan kebutuhan, c). Uji kompetensi bagi widyaiswara, d). Penyiapan infrastruktur untuk mendukung database kewidyaiswaraan, dan e). Perbaikan layanan berbasis IT terutama dalam sistem penilaian angka kredit dengan menerapkan digitalisasi layanan DUPAK On Line. Sedangkan untuk poin 2) Grand Design Pembinaan widyaiswara meliputi a) Profil widyaiswara yang profesional (World Class Trainer) melalui strategi: (1). Program pengembangan kompetensi (Pendidikan, Diklat dan Non Diklat). (2). Program pelayanan (Pelayanan berbasis IT untuk mencapai pelayanan yang berkualitas: murah, cepat, mudah). (3). Program pembinaan (Quality Standar, Quality Assurance dan Quality Control)

Untuk poin 3) Program Pelayanan (Pelayanan berbasis IT untuk mencapai pelayanan yang berkualitas: murah, cepat dan mudah) dengan: 
(a). Membangun Database Widyaiswara Nasional (b). Penetapan NIWN (Nomor Identitas Widyaiswara Nasional). (c). Membangun Website Pusat Pembinaan Widyaiswara yang interaktif, (d). Layanan DUPAK On Line dan (e) Pengembangan Sistem Informasi Seleksi calon widyaiswara (On Line)

Terakhir di poin 4) Program Pengembangan Kompetensi Diklat dan Non Diklat antara lain: (a) Membangun Sistem Diklat Calon Widyaiswara, (b) Membangun Sistem Diklat Berjenjang (c) Mengembangkan Diklat Teknis yang mendukung Tugas dan Fungsi Widyaiswara, dan (d) Pengembangan Kompetensi Non Diklat bagi Widyaiswara

Berikutnya 5) Program Pembinaan (Quality Standard, Quality Assurance dan Quality Control) dengan melakukan kegiatan, antara lain: (a). Menyusun Kebijakan Kewidyaiswaraan (b). Melakukan fasilitas Program Pengembangan Kompetensi Widyaiswara (Diklat Calon Widyaiswara, Diklat Berjenjang, dan TOT Substansi), (c). Akreditasi Penyelenggaraan Diklat Kewidyaiswaraan (d). Melakukan Monitoring dan Evaluasi Perkembangan ProfesionalisasiKewidyaiswaraan, terkait dengan: (1). Mindset dan karakter terhadap pola pikir, wawasan, kompetensi dan kinerja, (2). Akses dan kualitas pelatihan, dan (3). Manajemen Diklat.

Sedangkan untuk poin 6) Peran Penting Widyaiswara, meliputi: a) Bagian Tenaga Kediklatan b). Tim Fasilitator dan c) sebagai Coach. Pada bagian 7). Strategi Pengembangan Kapasitas terdapat 4 bagian yaitu a). Pengelolaan diri dan Investasi diri (tidak terjebak pada kegiatan Dikjartih, zona nyaman, b). Pengembangan kapasitas diri: aktif pada forum-forum ilmiah, knowledge sharing, update informasi dan pengayaan materi, c). Aktif menulis dan mengikuti kompetisi/lomba penulisan KTI, d). Membangun networking, mampu berkomunikasi dengan baik dan penguasaan IT. 
Berdasarkan Peraturan Pemerintah tentang Manajemen PNS Pasal 203 - 224 Perencanaan Pengembangan Kompetensi ASN meliputi 1). Mengembangkan kompetensi adalah upaya pemenuhan kebutuhan kompetensi PNS dengan standar kompetensi Jabatan dan rencana pengembangan karier, 2). PNS dan PPPK (Pegawai Pemerintah dengan Perjanjian Kerja) memiliki kesempatan yang sama 3). Rencana Pengembangan Kompetensi berisi inventarisasi jenis pengembangan kompetensi yang diperlukan setiap ASN dan rencana pelaksanaan. 4). Pengembangan berbasis analisis kesenjangan kompetensi dan analisis kesenjangan kinerja 5). Kebutuhan dan rencana pengembangan kompetensi ditetapkan oleh PPK, dan 6). Kebutuhan dan rencana pengembangan kompetensi dimasukkan ke dalam sistem informasi pengembangan kompetensi LAN.

Dari penjelasan di atas dapat diketahui bahwa seorang widyaiswara dituntut untuk terus mengembangkan kapasitas dirinya terutama terkait dalam kegiatan ilmiah dan selalu update informasi. Kesempatan telah dibuka lebar sesuai aturan regulasi dan kini hanya menunggu action dari widyaiswara untuk menangkap kesempatan ini. Tuntutan regulasi dan masyarakat terhadap kinerja ASN seyogyanya menggugah widyaiswara untuk terus belajar, belajar dan belajar lagi. Jika ingin mewujudkan ASN berkelas dunia maka widyaiswara pun harus berkelas dunia dan setidaknya harus memiliki paradigma terhadap lima kriteria kinerja ASN yakni: profesional, integritas, orientasi kepublikan, budaya pelayanan yang tinggi, serta memiliki wawasan global. Kelima kriteria tersebut perlu dilakukan oleh widyaiswara secara berkesinambungan guna memenuhi tuntutan kualifikasi widyaiswara yang mumpuni untuk mewujudkan ASN yang berkelas dunia tahun 2025 


\section{BAGIAN II}

PERSEPSI PESERTA DIKLAT TERHADAP URGENSI BAHASA INGGRIS DALAM OPTIMALISASI KINERJA

\section{A. Pendahuluan \\ 1. Latar Belakang:}

"Mba, tolong ya saya segera dipanggil ikut diklatpim III tahun ini, supaya saya tidak kena aturan persyaratan harus ikut tes bahasa Inggris tahun depan" (melampirkan nilai TOEFL, maksudnya), pinta salah seorang calon peserta diklat kepemimpinan. "Bu, tadi ibu beberapa kali menggunakan bahasa Inggris saat mengajar, saya suka itu, walau saya belum bisa berbahasa Inggris. Saya menjadi termotivasi untuk belajar bahasa Inggris lagi," ungkap peserta diklat. "Bu kost (penjelasan: mengucapkan kata kost untuk coach), saya berterima kasih telah dibimbing oleh ibu." Itulah beberapa komentar atau respon peserta diklat yang nota bene adalah Aparatur Sipil Negara (ASN) terkait dengan kemampuan berbahasa Inggris.

Dari beberapa komentar peserta diklat di atas yang notabene adalah pejabat eselon III dapat kita maklumi ada sebagian yang belum percaya diri 
dalam menunjukkan kemampuan dan keterampilan berbahasa Inggris, namun ada pula yang berkeinginan kuat untuk memiliki kemampuan itu, dan ada pula yang sudah percaya diri namun secara pengucapan berbahasa Inggris harus diperbaiki. Itu semua menunjukkan bahsa Inggris erat kaitannya dalam dunia birokrasi dan tentu saja dalam dunia pelatihan bagi ASN. Dan memang tak ada yang dapat memungkiri urgensi peran bahasa Inggris dalam keseharian dan dalam dunia birokrasi.sehingga penting untuk dikuasai oleh ASN, namun demikian masih ditemukan berbagai kendala dalam pencapaiannya sebagaimana pernyataan peserta diklatpim III di atas yang masih memiliki keterbatasan kemampuan berbahasa Inggris.

Dalam dunia birokrasi, banyak upaya peningkatan dan perbaikan bagi ASN yang harus dilakukan dalam meminimalisir masalah pengembangan kompetensi. Salah satu yang kerap ditemui di dalam pelaksanaan tugas adalah banyak ASN yang belum memiliki kepercayaan diri dan kemampuan untuk menunjukan performa saat berinteraksi dengan orang asing atau ekspatriat penutur bahasa Inggris, baik saat membangun jejaring, negosiasi, benchmarking, konferensi, workshop, dan lain-lain.

Padahal saat ini pembentukan SMART ASN sedang digalakkan oleh Pemerintah, dimana kriterianya adalah penguasaan informasi dan teknologi, berwawasan global dan profesional. Salah satu upaya dalam mendukung pencapaian SMART ASN dan perwujudan birokrasi berkelas dunia maka ASN harus ditingkatkan kepercayaan diri dan kemampuan berkomunikasi dalam bahasa Inggris karena harus berwawasan global. Di samping itu ada pencapaian besar yang harus terwujud di tahun 2025 bagi ASN yaitu World Class Bureaucracy. Jika dikatakan tingkat dunia maka tak pelak lagi, kemampuan berbahasa Inggris merupakan sebuah keniscayaan yang harus dimiliki oleh ASN. 


\section{Perumusan Masalah}

Dari latar belakang yang diungkapkan di atas maka rumusan masalah penelitian ini:

"Bagaimana persepsi peserta terhadap urgensi bahasa Inggris dalam optimalisasi kinerja?"

\section{Metode Penelitian}

Metode penelitian ini menggunaan survey dengan teknik kuesioner dan pendekatan random sampling kepada sejumlah alumni Diklat Kepemimpinan Tingkat III.

4. Manfaat Penelitian

Penelitian ini diharapkan dapat memotivasi ASN untuk meningkatkan kemampuan dan keterampilan berbahasa Inggris.

\section{B. Pembahasan}

\section{Aparatur Sipil Negara di Era Penuh Tantangan yang Mendunia}

Pemerintah melakukan banyak terobosan dalam memperbaiki situasi dan kondisi pelayanan publik yang dilakukan ASN. Salah satunya adalah perubahan undang-undang kepegawaian, Undang-Undang Nomor 8 Tahun 1974 juncto Undang-Undang Nomor 43 Tahun 1999 tentang Pokok-Pokok Kepegawaian diganti dengan Undang-Undang Nomor 5 Tahun 2014 tentang ASN resmi diundangkan di lembaran negara dan mulai diberlakukan sejak 15 Januari 2014. Di antara perubahan mendasar yang terjadi dalam manajemen SDM aparatur adalah perubahan dari pendekatan personnel administration yang hanya berupa pencatatan administratif kepegawaian kepada human resource management, yang memandang sumber daya 
manusia aparatur sebagai aset negara yang harus dikelola, dihargai, dan dikembangkan dengan baik.

ASN sebagai sebuah profesi harus memiliki standar pelayanan profesi, nilai dasar, kode etik dan kode perilaku profesi, pendidikan dan pengembangan profesi, serta memiliki organisasi profesi yang dapat menjaga nilai-nilai dasar profesi. Untuk memperkuat sistem dalam birokrasi, ASN terdiri dari Pegawai Negeri Sipil (PNS) dan Pegawai Pemerintah dengan Perjanjian Kerja (PPPK) dengan basis utama kompetensi, kompetisi, dan kinerja. Perubahan mendasar lain, UU ASN ini juga akan mengubah dari pendekatan closed career system yang sangat berorientasi pada senioritas dan kepangkatan, kepada open career system yang mengedepankan kompetisi dan kompetensi ASN dalam promosi dan pengisian jabatan.

Tuntutan perubahan dengan sangat cepat membuat pemerintah merasa perlu mengusung semangat Revolusi Mental sehingga ASN diharapkan menerapkan semangat tersebut dalam pelaksanaan tugas. Salah satu fungsi penyelenggaraan pemerintahan yang dilakukan oleh ASN adalah pelayanan publik. Peraturan perundangan Indonesia telah memberikan landasan untuk penyelenggaraan pelayanan publik yang berdasarkan atas asas-asas umum pemerintahan yang baik. Dalam mewujudkan Reformasi Birokrasi dibutuhkan perbaikan dan kinerja pelayanan publik yang menjunjung tinggi mentalitas spiritual. Agar mampu melaksanakan fungsi pemerintah dengan baik maka aparatur harus profesional, tanggap, aspiratif terhadap tuntutan masyarakat yang dilayani.

Karena ASN merupakan unsur sumberdaya manusia yang penting dalam pembangunan maka harus dapat diberdayakan dengan optimal. Menurut Wikipedia, sumberdaya manusia atau biasa disingkat menjadi SDM 
adalah potensi yang terkandung dalam diri manusia untuk mewujudkan perannya sebagai makhluk sosial yang adaptif dan transformatif yang mampu mengelola dirinya sendiri serta seluruh potensi yang terkandung di dalam dirinya menuju tercapainya kesejahteraan kehidupan dalam tatanan yang seimbang dan berkelanjutan. Dalam pengertian praktis sehari-hari, SDM lebih dimengerti sebagai bagian integral dari sistem yang membentuk suatu organisasi.

SDM adalah manusia yang berada dan bekerja dalam suatu organisasi yang terdiri atas para pimpinan dan bawahan/staf pelaksana. Mereka adalah potensi manusiawi yang merupakan aset dan berfungsi sebagai modal yang menggerakkan organisasi dalam rangka mencapai tujuan. Basyir Barthos (2001) memaknai sumber daya manusia adalah penduduk dari suatu negara. Sumber daya manusia didefinisikan bukan dengan apa yang sumber daya manusia lakukan, tetapi apa yang sumber daya hasilkan (David Ulrich dalam Robert L. Malthis, 2001).

Dalam suatu organisasi modern, peran SDM selalu menjadi tumpuan dan sekaligus aset utama. Oleh karena itu, mereka harus selalu mendapat pengetahuan dan pemahaman masalah terkini dengan baik (Well Informed) mempunyai keterampilan yang serba bisa (Good Skill) dan tentu saja memiliki sikap dan perilaku yang baik (Good Attitude). Dengan SDM yang profesional, berpengetahuan dan berpandangan luas, terampil dan memiliki sikap dan perilaku baik, diharapkan tujuan organisasi dapat tercapai dengan baik sesuai yang diharapkan.

Dengan demikian dengan diberlakukannya UU ASN tersebut maka ASN akan menjadi suatu profesi. Apalagi belum lama ini telah terbit Peraturan Pemerintah Nomor 11 Tahun 2017 tentang Manajemen Kepegawaian PNS. 
Untuk itu PNS sebagai bagian dari ASN harus menunjukkan pelayanan yang profesional sebagaimana UU 5 Tahun 2014 Pasal 3.

Menurut Sanusi, et. al dalam Soetjipto (2000) bahwa ciri-ciri utama suatu profesi itu antara lain suatu jabatan yang memiliki fungsi dan signifikansi sosial yang menentukan (krusial) dan jabatan yang menuntut keterampilan/keahlian tertentu. Selain itu dalam memberikan layanan kepada masyarakat anggota profesi itu berpegang teguh pada kode etik yang timbul yang dikontrol oleh organisasi profesi. Ini berarti bahwa pekerjaan yang bersifat profesional adalah pekerjaan yang hanya dapat dilakukan oleh mereka yang khusus dipersiapkan untuk itu dan bukan pekerjaan yang dilakukan oleh mereka yang karena tidak memperoleh pekerjaan yang lain.

Menurut Affandi (2002) dalam The Little Life Gallery Blog, ada empat ciri-ciri yang bisa ditenggarai sebagai petunjuk atau indikator untuk melihat tingkat profesionalitas seseorang yaitu:

1. Penguasaan ilmu pengetahuan seseorang di bidang tertentu, dan ketekunan mengikuti perkembangan ilmu yang dikuasai.

2. Kemampuan seseorang dalam menerapkan ilmu yang dikuasai, khususnya yang berguna bagi kepentingan sesama.

3. Ketaatan dalam melaksanakan dan menjunjung tinggi etika keilmuan, serta kemampuannya untuk memahami dan menghormati nilai-nilai sosial yang berlaku dalam lingkungannya.

4. Besarnya rasa tanggung jawab terhadap Tuhan, bangsa dan negara, masyarakat, keluarga serta diri sendiri atas segala tindak lanjut dan perilaku dalam mengemban tugas berkaitan dengan penugasan penerapan bidang ilmu yang dimilliki. 
Dari apa yang dijelaskan oleh Sanusi dan Affandi di atas dapat disimpulkan bahwa seorang ASN seyogyanya menjunjung tinggi profesionalitas kerja mereka. Salah satu alasannya karena sebagai aparatur, ASN memiliki fungsi dan signifikansi sosial yang menentukan (krusial).

Setiap ASN memiliki hak dan kesempatan untuk mengembangkan kompetensi antara lain melalui: pendidikan dan pelatihan, seminar, kursus, dan penataran. Pengembangan kompetensi ini harus dievaluasi oleh pejabat yang berwenang dan digunakan sebagai salah satu dasar dalam pengangkatan jabatan dan pengembangan karir. Selain itu pengembangan kompetensi ini wajib disusun dalam rencana pengembangan kompetensi tahunan dalam rencana kerja anggaran tahunan instansi.

Di dalam UU ASN dijelaskan tentang Hak dan Kesempatan bagi ASN baik PNS maupun PPPK mengikuti pengembangan kompetensi, yaitu:

a. Memiliki hak dan kesempatan yang sama untuk diikutsertakan dalam pengembangan kompetensi, dengan memperhatikan hasil penilaian kinerja dan penilaian kompetensi yang bersangkutan.

b. Pengembangan kompetensi sebagaimana dimaksud dilakukan paling kurang 20 jam pelajaran dalam 1 (satu) tahun.

Jenis pengembangan dapat dilaksanakan melalui:

1. Pendidikan Formal

1) Pengembangan kompetensi dalam bentuk pendidikan dilakukan untuk meningkatkan pengetahuan dan keahlian PNS melalui pendidikan formal sesuai dengan peraturan perundang-undangan.

2) Pengembangan kompetensi dalam bentuk pendidikan formal sebagaimana dimaksud diatas dilaksanakan dengan pemberian tugas belajar. 
3) Pemberian tugas belajar sebagaimana dimaksud diberikan dalam rangka memenuhi kebutuhan standar kompetensi jabatan dan pengembangan karir.

\section{Pelatihan}

1) Pengembangan kompetensi dalam bentuk pelatihan dilakukan melalui jalur pelatihan klasikal dan non-klasikal.

2) Pengembangan kompetensi dalam bentuk pelatihan klasikal sebagaimana dimaksud, dilakukan melalui proses pembelajaran tatap muka di dalam kelas, melalui pelatihan, seminar, kursus, penataran, sosialisasi, workshop, semiloka, sekolah kader serta bentuk lain yang sejenis.

3) Pengembangan kompetensi dalam bentuk pelatihan non-klasikal sebagaimana dimaksud dilakukan melalui e-learning, bimbingan di tempat kerja, pelatihan jarak jauh, magang dan pertukaran antara PNS dan pegawai swasta serta bentuk lain yang sejenis.

4) Pengembangan kompetensi dalam bentuk pelatihan dilakukan melalui jalur pelatihan klasikal dan non-klasikal.

5) Pengembangan kompetensi dalam bentuk pelatihan klasikal sebagaimana dimaksud, dilakukan melalui proses pembelajaran tatap muka di dalam kelas, melalui pelatihan, seminar, kursus, penataran, sosialisasi, workshop, semiloka, sekolah kader serta bentuk lain yang sejenis.

6) Pengembangan kompetensi dalam bentuk pelatihan non-klasikal sebagaimana dimaksud dilakukan melalui e-learning, bimbingan di tempat kerja, pelatihan jarak jauh, magang dan pertukaran antara PNS dan pegawai swasta serta bentuk lain yang sejenis. 
Dalam era globalisasi yang penuh kompetisi, ASN yang ideal dan kompetitif merupakan keniscayaan dan tuntutan publik. Beberapa hal yang harus diperhatikan untuk mewujudkan ASN yang ideal dan kompetitif adalah dengan membuka formasi/kualifikasi ASN yang sesuai dengan arah pembangunan nasional serta potensi daerah. Selanjutnya, pengadaan ASN yang transparan, objektif dan fairness untuk mengembalikan kepercayaan masyarakat sekaligus menjaring putra-putri terbaik bangsa. Ketiga, Meningkatkan profesionalisme, yakni meningkatkan kompetensi, kualifikasi dan kinerja sebagaimana yang diamanatkan UU ASN. Saat ini sangat dibutuhkan ASN yang memiliki karakteristik berwawasan global, menguasai teknologi informasi dan komunikasi (TIK) dan bahasa, memiliki kemampuan networking tinggi dengan kemampuan skill multitasking yang proporsional. Terkait dengan wawasan global, otomatis kemampuan berbahasa Inggris mutlak diperlukan karena bahasa Inggris termasuk bahasa internasional yang penggunaannya sangat mendunia.

\section{Peran Bahasa Inggris dalam Pelaksanaan Tugas ASN}

Bahasa adalah suatu sistem simbol lisan yang arbitrer yang dipakai oleh anggota suatu masyarakat bahasa untuk berkomunikasi dan berinteraksi antar sesamanya, berlandaskan pada budaya yang mereka miliki bersama (Soenjono Dardjowidjojo, 2005). Sedangkan menurut pendapat ahli bahasa lain, bahasa adalah sistem lambang bunyi yang arbitrer yang digunakan oleh para anggota kelompok sosial untuk bekerja sama, berkomunikasi, dan mengidentifikasikan diri (Krisdalaksana, 1983).

Bahasa memiliki dua fungsi yang mendasar yaitu sebagai alat berpikir dan berkomunikasi. Tanpa bahasa manusia akan mengalami kesulitan dalam berinteraksi dan bekerja sama dengan orang lain. Sebab itu untuk dapat berkomunikasi dan berinteraksi dengan orang asing secara lisan 
maupun tulisan, penguasaan bahasa asing sangat diperlukan, dalam hal ini bahasa Inggris, yang merupakan bahasa yang banyak dipakai secara luas oleh penduduk dunia terutama dalam era globalisasi di abad ke-21 ini. The Economist, sebagaimana dikutip oleh Hasman (2000), memberitakan bahwa bahasa Inggris tetap menjadi bahasa standar dunia dan tak ada yang dapat mengancam keberadaan atau popularitas bahasa Inggris yang sudah mendunia. Memang tak dapat disangkal bahwa bahasa Inggris di Indonesia merupakan bahasa asing pertama yang dianggap penting untuk tujuan pengembangan ilmu pengetahuan, teknologi dan seni budaya serta pengembangan hubungan antar bangsa.

Bahasa Inggris penting di era globalisasi karena penggunaannya sangat mendunia dalam dunia teknologi, pendidikan, politik, perdagangan, dan lain sebagainya. Negara di Asia banyak yang menjadikan bahasa Inggris sebagai bahasa kedua sesudah bahasa nasional mereka, misalnya Filipina dan Malaysia. Dalam dunia pendidikan bahasa Inggris digunakan pula sebagai "Medium of Instruction"

Dalam dunia kerja dan birokrasi, bahasa Inggris sangat diperlukan karena sering kali kementerian atau lembaga pemerintah mendapatkan surat penting dan kunjungan dari kementerian atau lembaga negara lain. Hal ini tentunya memerlukan respon dan penyambutan dalam bahasa Inggris utamanya, sebagai bahasa asing pertama yang diakui secara internasional.

\section{Upaya Peningkatan Kemampuan dan Keterampilan Berbahasa Inggris bagi ASN}

ASN yang kompeten, inovatif dan profesional menjadi kebutuhan organisasi guna menjawab berbagai permasalahan dan tantangan tersebut. Berbagai tantangan tersebut, mendorong birokrasi untuk terus 
melakukan perubahan melalui upaya perbaikan untuk menemukan, mencari sekaligus mengimplementasikan gagasan baru menuju organisasi berkinerja tinggi. Mencermati permasalahan dan tantangan tersebut, upaya peningkatan kinerja dan kapasitas Aparatur Sipil Negara sangatlah dibutuhkan. Begitu pula dalam rangka pencapaian target reformasi birokrasi yaitu pemerintahan berkelas dunia (World Class Government) dan sesuai dengan amanat RPJMN 3 (2015 - 2019) pembangunan ASN memasuki tahap Smart ASN, ke depan ASN dituntut harus memiliki wawasan global, penguasaan teknologi informasi, bahasa asing, dan jejaring kerja (networking), serta integritas.

Yudi Chrisnandi menyatakan bahwa menjadikan ASN yang ideal dan kompetitif di era globalisasi merupakan tuntutan publik dan target yang harus dicapai (https://www.menpan.go.id/site/cerita-sukses-rb/5418menuju-smart-asn-2019). Dalam penjelasannya beliau menuturkan tiga sasaran utama untuk mewujudkan SMART ASN di tahun 2019. Pertama, Perencanaan ASN dengan membuka formasi/kualifikasi ASN yang sesuai dengan arah pembangunan nasional serta potensi daerah. Kedua, Pengadaan ASN yang sesuai dengan arah pembangunan nasional serta potensi daerah. Kedua, Pengadaan ASN yang transparan, objektif dan fairness untuk mengembalikan kepercayaan masyarakat sekaligus menjaring putra putri terbaik bangsa. Ketiga, Meningkatkan profesionalisme, yakni meningkatkan kompetensi, kualifikasi dan kinerja sebagaimana diamanatkan UU ASN. Dari ketiga sasaran SMART ASN tersebut maka implementasinya harus segera terwujud secara simultan sehingga terbentuklah SMART ASN yang memiliki karakteristik berwawasan global, menguasai TIK dan bahasa, memiliki kemampuan networking tinggi dengan kemampuan skill multitasking yang proporsional. 
Kepala Balai Diklat Bahasa LAN RI, Agung Nugroho, menyatakan dalam arahan saat membuka Sosialisasi Modul ECSCS Test Preparation Course 15 Nopember 2016 lalu, "Mengacu pada UU Aparatur Sipil Negara, disebutkan secara tegas dalam Undang-Undang Nomor 5 Tahun 2014 tentang Aparatur Sipil Negara bahwa Lembaga Administrasi Negara diamanatkan untuk melakukan penguatan fungsi utama di bidang kediklatan yang meliputi quality standard, quality assurance dan quality control. Ketiga aspek tersebut diyakini dapat mempercepat terwujudnya peran dan tugas utama LAN dalam mewujudkan ASN berkelas dunia." Hal ini sejalan dengan pernyataan Yudi Chrisnandi bahwa seorang ASN perlu ditingkatkan profesionalisme dengan melakukan training need assessment (TNA) terlebih dahulu yakni pengembangan kapasitas/diklat untuk mengisi gap kompetensi antara kompetensi individu dengan kompetensi jabatannya. Meski di dalam pelaksanaannya untuk peningkatan profesionalisma tidak selalu dilakukan melalui diklat, dapat pula melalui seminar, kursus, workshop dan sebagainya.

Meskipun perbaikan dan inovasi terus menerus dilakukan dalam penguatan fungsi utama bidang kediklatan ini, yaitu sebagai upaya dalam mendukung pencapaian SMART ASN dan perwujudan birokrasi berkelas dunia namun demikian masih ditemukan berbagai kendala dalam pencapaiannya. Salah satu yang menjadi kendala yang dirasakan saat ini, adalah terkait dengan pengembangan kompetensi bahasa Inggris ASN. Dimana masih kita temui pejabat atau pegawai ASN yang kurang perform dalam berinteraksi dengan komunitas internasional seperti membangun jejaring, negosiasi, benchmarking, konferensi, workshop, dan lain-lain. 
Oleh karena itu dikeluarkanlah kebijakan tentang persyaratan untuk mengikuti Diklat Kepemimpinan dimana peserta diwajibkan untuk memiliki kemampuan dalam berbahasa Inggris dengan nilai tertentu berdasarkan hasil tes seperti: TOEFL (Test of English as a Foreign Language) sesuai dengan tingkat Diklat Kepemimpinan yang akan diikuti.

Adapun beberapa alasan utama mengapa bahasa Inggris penting bagi ASN adalah sebagai berikut:

a. Pengembangan kompetensi dalam bentuk pendidikan dilakukan untuk meningkatkan pengetahuan dan keahlian PNS melalui pendidikan formal sesuai dengan peraturan perundang-undangan. Pengembangan kompetensi dalam bentuk pendidikan formal sebagaimana dimaksud di atas dilaksanakan dengan pemberian tugas belajar. Pemberian tugas belajar sebagaimana dimaksud diberikan dalam rangka memenuhi kebutuhan standar kompetensi jabatan dan pengembangan karir. Jika ini diberikan maka tantangan berikutnya adalah ASN harus banyak berhubungan, mendengar, membaca atau mengambil referensi dari buku berbahasa Inggris dan dalam pembelajaran akan berkomunikasi atau mendengar istilah dalam bahasa Inggris

b. Pengembangan kompetensi dalam bentuk pelatihan dilakukan melalui jalur pelatihan klasikal dan non-klasikal. Pengembangan kompetensi dalam bentuk pelatihan klasikal sebagaimana dimaksud, dilakukan melalui proses pembelajaran tatap muka di dalam kelas, melalui pelatihan, seminar, kursus, penataran, sosialisasi, workshop, semiloka, sekolah kader serta bentuk lain yang sejenis. Pengembangan kompetensi dalam bentuk pelatihan non-klasikal sebagaimana dimaksud dilakukan melalui e-learning, bimbingan di tempat kerja, pelatihan jarak jauh, magang dan pertukaran antara PNS dan pegawai 
swasta serta bentuk lain yang sejenis. Kedua pengembangan tersebut membutuhkan pula kemampuan berbahasa Inggris apalagi jika ada narasumber atau peserta yang diundang berasal dari negara-negara Asia, Eropa dan lain-lain yang menggunakan bahasa Inggris sebagai bahasa internasional.

c. ASN diharapkan dapat meningkatkan pengembangan kompetensi berkomunikasi bahasa Inggris dan menjadi salah satu upaya pencapaian birokrasi kelas dunia. SMART ASN adalah target Rencana Pembangunan Jangka Menengah bagian kepegawaian yang harus dicapai oleh pemerintah pada tahun 2019. SMART ASN memiliki ciriciri: penguasaan informasi dan teknologi, berwawasan global dan profesional. Implementasi ketiga sasaran SMART ASN 2019 harus dilakukan secara simultan agar terwujud SMART ASN yang memiliki karakteristik berwawasan global, menguasai teknologi informasi komunikasi (TIK) dan bahasa, memiliki kemampuan networking tinggi dengan kemampuan skill multitasking yang proporsional.

\section{Hasil Temuan dan Pembahasan}

a. Pengumpulan Data

Penyusun memberikan kuesioner kepada sejumlah alumni diklatpim III yang merupakan pejabat eselon III Kementerian Agama pusat maupun daerah terkait dengan upaya peningkatan keterampilan berbahasa Inggris bagi pegawai Kementerian Agama. Karena kesibukan yang mereka miliki luar biasa padatnya maka dari tiga puluh pejabat eselon III Kementerian Agama pusat dan daerah yang telah penulis kirimkan kuesioner, hanya dua belas orang yang mengembalikan kuesioner. 
b. Pengolahan dan Analisis Data

Kuesioner yang masuk kemudian di entry dengan cara:

Data dari tiap responden yang telah melingkari jawaban dberi skor dengan rentang $1-5$

Contoh Responden 1

\begin{tabular}{|c|c|}
\hline No. pertanyaan & Skor \\
\hline 1 & 3 \\
\hline 2 & 3 \\
\hline 3 & 3 \\
\hline 4 & 4 \\
\hline 5 & 5 \\
\hline
\end{tabular}

Kemudian angka skor dikalikan jumlah angka skor yang muncul tiap responden

Contoh

$1 \times 0=0$

$2 \times 0=0$

$3 \times 3=9$

$4 \times 1=4$

$5 \times 1=5$

Jadi, $0+0+9+4+5=18$

Skor maksimal dari tiap butir soal adalah 5 x jumlah pertanyaan $=25$

Prosentase jawaban Responden 1 adalah 18/25 = 0,72

Maka diperoleh data dari jumlah responden: 


\begin{tabular}{|l|c|c|}
\hline \multicolumn{1}{|c|}{ RESPONDEN } & SKOR & PROSENTASE \\
\hline Responden 1 & 18 & 0,72 \\
\hline Responden 2 & 18 & 0,72 \\
\hline Responden 3 & 15 & 0,6 \\
\hline Responden 4 & 18 & 0,72 \\
\hline Responden 5 & 9 & 0,36 \\
\hline Responden 6 & 16 & 0,64 \\
\hline Responden 7 & 15 & 0,6 \\
\hline Responden 8 & 11 & 0,44 \\
\hline Responden 9 & 16 & 0,64 \\
\hline Responden 10 & 10 & 0,4 \\
\hline Responden 11 & 11 & 0,44 \\
\hline Responden 12 & 19 & 0,76 \\
\hline
\end{tabular}

Dari hasil jawaban responden terhadap kuesioner tersebut diperoleh: 


\begin{tabular}{|c|c|c|c|c|c|c|c|}
\hline 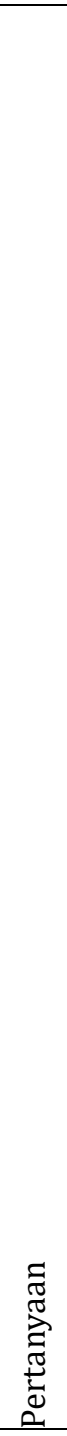 & 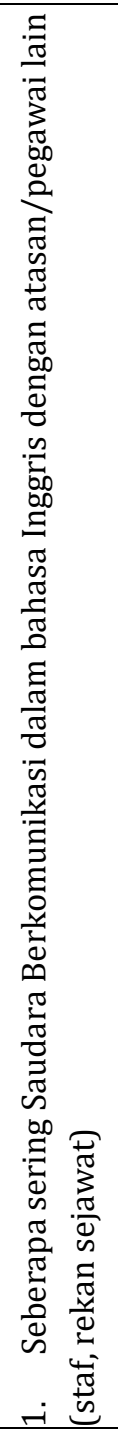 & 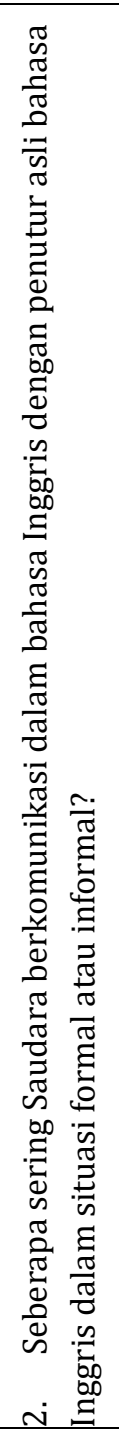 & 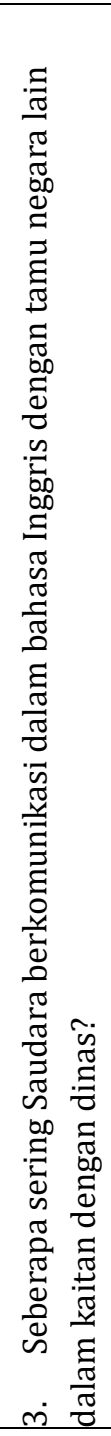 & 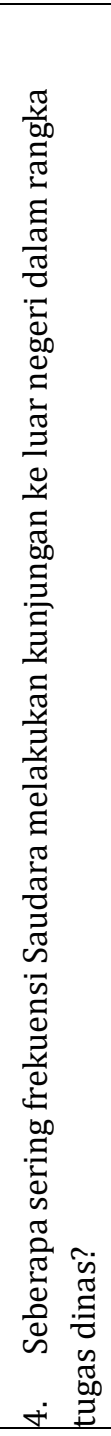 & 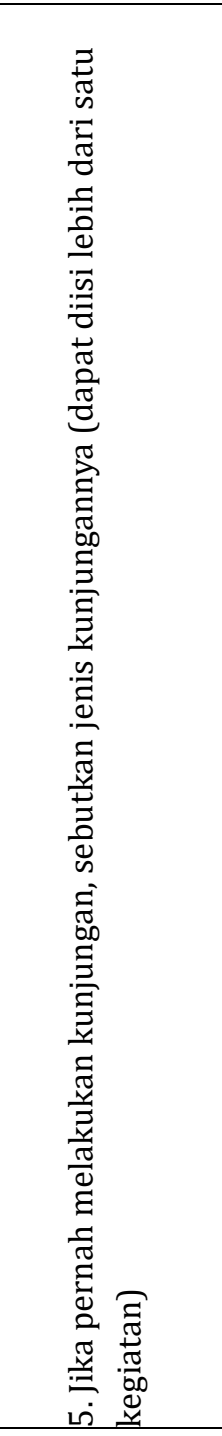 & 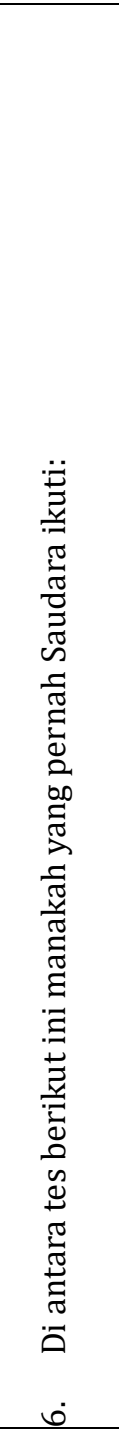 & 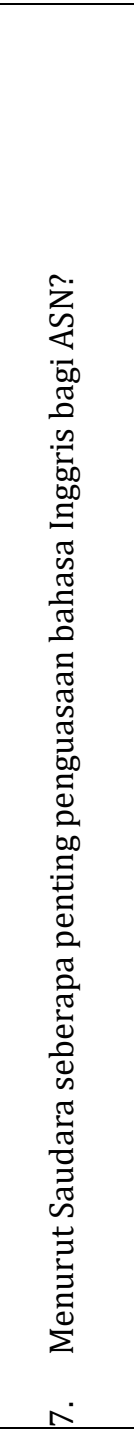 \\
\hline & Q1A & Q2A & Q3A & $\mathrm{Q} 4 \mathrm{~A}$ & Q5A & Q6A & Q7A \\
\hline R1 & Jarang & Jarang & Jarang & Sering & $\begin{array}{l}\text { Penyiapan } \\
\text { sarana } \\
\text { prasarana haji }\end{array}$ & TOEFL & $\begin{array}{l}\text { Sangat } \\
\text { penting }\end{array}$ \\
\hline R2 & jarang & jarang & sering & jarang & $\begin{array}{l}\text { Seminar, } \\
\text { Workshop }\end{array}$ & $\begin{array}{l}\text { TOEFL, } \\
\text { IELTS }\end{array}$ & $\begin{array}{l}\text { Sangat } \\
\text { penting }\end{array}$ \\
\hline
\end{tabular}




\begin{tabular}{|c|c|c|c|c|c|c|c|}
\hline R3 & jarang & jarang & jarang & $\begin{array}{l}\text { tidak } \\
\text { pernah }\end{array}$ & belum pernah & $\begin{array}{l}\text { tidak } \\
\text { ada }\end{array}$ & $\begin{array}{l}\text { Sangat } \\
\text { penting }\end{array}$ \\
\hline $\mathrm{R} 4$ & jarang & $\begin{array}{l}\text { sangat } \\
\text { jarang }\end{array}$ & jarang & $\begin{array}{l}\text { sangat } \\
\text { jarang }\end{array}$ & belum pernah & $\begin{array}{l}\text { TOEFL, } \\
\text { TOEIC }\end{array}$ & $\begin{array}{l}\text { Sangat } \\
\text { penting }\end{array}$ \\
\hline R5 & $\begin{array}{l}\text { tidak } \\
\text { pernah }\end{array}$ & $\begin{array}{l}\text { tidak } \\
\text { pernah }\end{array}$ & $\begin{array}{l}\text { tidak } \\
\text { pernah }\end{array}$ & $\begin{array}{l}\text { tidak } \\
\text { pernah }\end{array}$ & belum pernah & $\begin{array}{l}\text { belum } \\
\text { pernah }\end{array}$ & $\begin{array}{l}\text { Sangat } \\
\text { penting }\end{array}$ \\
\hline R6 & Jarang & jarang & jarang & $\begin{array}{l}\text { sangat } \\
\text { jarang }\end{array}$ & benchmarking & TOEFL & Penting \\
\hline R7 & Jarang & jarang & jarang & $\begin{array}{l}\text { tidak } \\
\text { pernah }\end{array}$ & belum pernah & TOEFL & $\begin{array}{l}\text { Sangat } \\
\text { penting }\end{array}$ \\
\hline R8 & $\begin{array}{l}\text { tidak } \\
\text { pernah }\end{array}$ & $\begin{array}{l}\text { tidak } \\
\text { pernah }\end{array}$ & $\begin{array}{l}\text { tidak } \\
\text { pernah }\end{array}$ & jarang & $\begin{array}{l}\text { workshop, } \\
\text { benchmarking }\end{array}$ & $\begin{array}{l}\text { belum } \\
\text { pernah }\end{array}$ & Penting \\
\hline R9 & jarang & jarang & $\begin{array}{l}\text { sangat } \\
\text { jarang }\end{array}$ & jarang & petugas haji & $\begin{array}{l}\text { belum } \\
\text { pernah }\end{array}$ & Penting \\
\hline R10 & $\begin{array}{l}\text { sangat } \\
\text { jarang }\end{array}$ & $\begin{array}{l}\text { tidak } \\
\text { pernah }\end{array}$ & $\begin{array}{l}\text { tidak } \\
\text { pernah }\end{array}$ & $\begin{array}{l}\text { tidak } \\
\text { pernah }\end{array}$ & belum pernah & TOEFL & Penting \\
\hline R11 & $\begin{array}{l}\text { tidak } \\
\text { pernah }\end{array}$ & $\begin{array}{l}\text { tidak } \\
\text { pernah }\end{array}$ & $\begin{array}{l}\text { sangat } \\
\text { jarang }\end{array}$ & $\begin{array}{l}\text { sangat } \\
\text { jarang }\end{array}$ & $\begin{array}{l}\text { studi banding, } \\
\text { monitoring }\end{array}$ & TOEFL & Penting \\
\hline R12 & $\begin{array}{l}\text { sangat } \\
\text { jarang }\end{array}$ & sering & sering & sering & $\begin{array}{l}\text { Studi banding, } \\
\text { monitoring, } \\
\text { rapat dinas }\end{array}$ & $\begin{array}{l}\text { TOEFL, } \\
\text { IELTS }\end{array}$ & Penting \\
\hline
\end{tabular}

Untuk pertanyaan esay maka diperoleh jawaban sebagai berikut: 


\begin{tabular}{|c|c|c|c|c|c|}
\hline 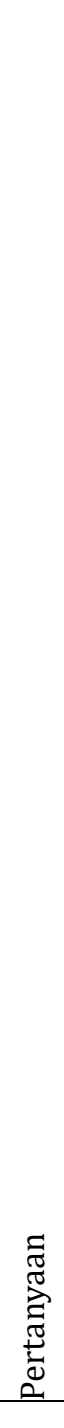 & 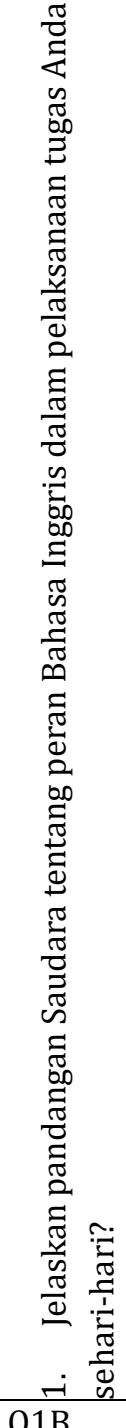 & 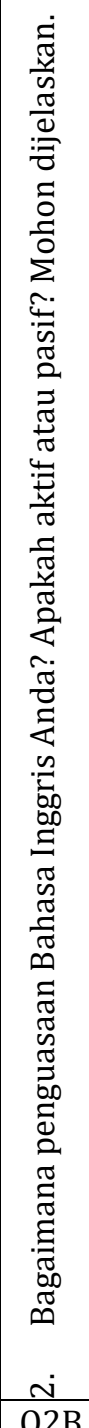 & 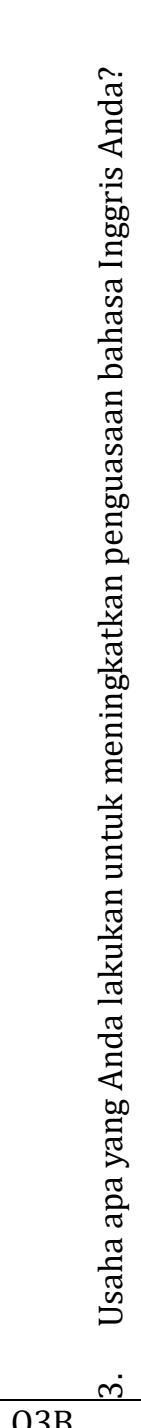 & 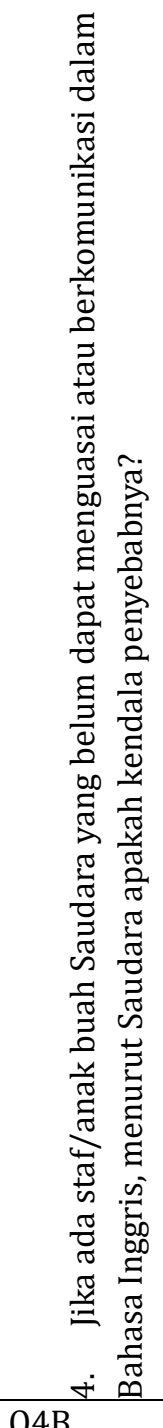 & 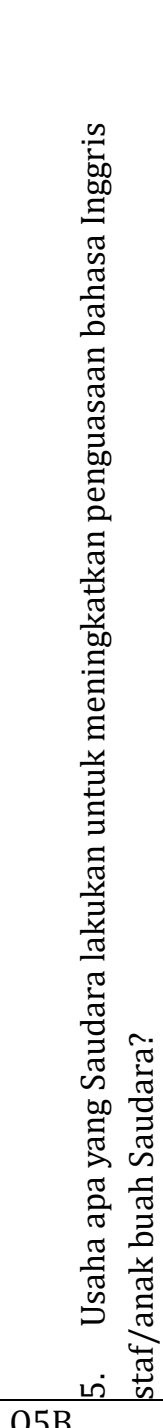 \\
\hline & Q1B & Q2B & Q3B & Q4B & Q5B \\
\hline
\end{tabular}




\begin{tabular}{|c|c|c|c|c|c|}
\hline R1 & $\begin{array}{l}\text { Sangat } \\
\text { penting }\end{array}$ & Pasif & $\begin{array}{l}\text { Berkomunikasi } \\
\text { dengan } \\
\text { keluarga } \\
\text { berbahasa } \\
\text { Inggris, } \\
\text { membaca } \\
\text { referensi } \\
\text { berbahasa } \\
\text { Inggris }\end{array}$ & $\begin{array}{l}\text { Latar belakang } \\
\text { pendidikan } \\
\text { dan kurangnya } \\
\text { tantangan } \\
\text { pekerjaan } \\
\text { yang } \\
\text { mengharuskan } \\
\text { mereka } \\
\text { berbahasa } \\
\text { Inggris }\end{array}$ & $\begin{array}{l}\text { Penugasan } \\
\text { untuk } \\
\text { mengeksplor } \\
\text { surat atau } \\
\text { dokumen } \\
\text { berbahasa } \\
\text { Inggris }\end{array}$ \\
\hline $\mathrm{R} 2$ & $\begin{array}{l}\text { sangat } \\
\text { penting }\end{array}$ & Aktif & $\begin{array}{l}\text { Berkomunikasi } \\
\text { dan diskusi } \\
\text { dengan orang } \\
\text { asing }\end{array}$ & $\begin{array}{l}\text { latar belakang } \\
\text { pendidikan }\end{array}$ & $\begin{array}{l}\text { anjuran kursus } \\
\text { bahasa inggris }\end{array}$ \\
\hline R3 & $\begin{array}{l}\text { sangat } \\
\text { penting }\end{array}$ & pasif & kursus & $\begin{array}{l}\text { kurangnya } \\
\text { tantangan } \\
\text { pekerjaan } \\
\text { yang } \\
\text { mengharuskan } \\
\text { mereka } \\
\text { berbahasa } \\
\text { Inggris }\end{array}$ & kursus \\
\hline
\end{tabular}




\begin{tabular}{|c|c|c|c|c|c|}
\hline R4 & $\begin{array}{l}\text { sangat } \\
\text { penting }\end{array}$ & pasif & $\begin{array}{l}\text { berbicara } \\
\text { langsung } \\
\text { dengan orang } \\
\text { asing, } \\
\text { menonton } \\
\text { film. Membaca } \\
\text { teks Inggris }\end{array}$ & $\begin{array}{l}\text { kurangnya } \\
\text { tantangan } \\
\text { pekerjaan } \\
\text { yang } \\
\text { mengharuskan } \\
\text { mereka } \\
\text { berbahasa } \\
\text { Inggris }\end{array}$ & $\begin{array}{l}\text { memotivasi utk } \\
\text { belajar bahasa } \\
\text { Inggris melalu } \\
\text { kursus, gemar } \\
\text { mempelajari } \\
\text { tata bahasa } \\
\text { Inggris }\end{array}$ \\
\hline R5 & $\begin{array}{l}\text { sangat } \\
\text { penting }\end{array}$ & pasif & kursus & $\begin{array}{l}\text { kurangnya } \\
\text { tantangan } \\
\text { pekerjaan } \\
\text { yang } \\
\text { mengharuskan } \\
\text { mereka } \\
\text { berbahasa } \\
\text { Inggris }\end{array}$ & $\begin{array}{l}\text { mengalokasikan } \\
\text { anggaran untuk } \\
\text { peningkatan } \\
\text { penguasaan } \\
\text { bahasa inggris }\end{array}$ \\
\hline R6 & $\begin{array}{l}\text { sangat } \\
\text { penting }\end{array}$ & aktif & $\begin{array}{l}\text { memperkaya } \\
\text { vocab dan } \\
\text { terus } \\
\text { melakukan } \\
\text { percakapan }\end{array}$ & $\begin{array}{l}\text { kurangnya } \\
\text { tantangan } \\
\text { pekerjaan } \\
\text { yang } \\
\text { mengharuskan } \\
\text { mereka } \\
\text { berbahasa } \\
\text { Inggris }\end{array}$ & $\begin{array}{l}\text { kursus } \\
\text { mengajak } \\
\text { berbincang } \\
\text { dalam bahasa } \\
\text { Inggris }\end{array}$ \\
\hline
\end{tabular}




\begin{tabular}{|c|c|c|c|c|c|}
\hline R7 & $\begin{array}{l}\text { sangat } \\
\text { penting }\end{array}$ & pasif & $\begin{array}{l}\text { kursus dan } \\
\text { belajar }\end{array}$ & $\begin{array}{l}\text { kurangnya } \\
\text { tantangan } \\
\text { pekerjaan } \\
\text { yang } \\
\text { mengharuskan } \\
\text { mereka } \\
\text { berbahasa } \\
\text { Inggris }\end{array}$ & $\begin{array}{l}\text { memotivasi utk } \\
\text { belajar }\end{array}$ \\
\hline R8 & $\begin{array}{l}\text { sangat } \\
\text { penting }\end{array}$ & pasif & belum ada & $\begin{array}{l}\text { latar belakang } \\
\text { pendidikan } \\
\text { dan kurangnya } \\
\text { tantangan } \\
\text { pekerjaan } \\
\text { yang } \\
\text { mengharuskan } \\
\text { mereka } \\
\text { berbahasa } \\
\text { Inggris }\end{array}$ & $\begin{array}{l}\text { dianjurkan } \\
\text { belajar sendiri }\end{array}$ \\
\hline R9 & $\begin{array}{l}\text { sangat } \\
\text { penting }\end{array}$ & pasif & $\begin{array}{l}\text { menggunakan } \\
\text { kamus }\end{array}$ & $\begin{array}{l}\text { latar belakang } \\
\text { pendidikan } \\
\text { dan kurangnya } \\
\text { tantangan } \\
\text { pekerjaan } \\
\text { yang } \\
\text { mengharuskan } \\
\text { mereka } \\
\text { berbahasa } \\
\text { Inggris }\end{array}$ & $\begin{array}{l}\text { menyuruh } \\
\text { belajar }\end{array}$ \\
\hline
\end{tabular}




\begin{tabular}{|c|c|c|c|c|c|}
\hline R10 & $\begin{array}{l}\text { sangat } \\
\text { penting }\end{array}$ & pasif & $\begin{array}{l}\text { Mengikuti } \\
\text { English Course }\end{array}$ & $\begin{array}{l}\text { latar belakang } \\
\text { pendidikan } \\
\text { dan kurangnya } \\
\text { tantangan } \\
\text { pekerjaan } \\
\text { yang } \\
\text { mengharuskan } \\
\text { mereka } \\
\text { berbahasa } \\
\text { Inggris }\end{array}$ & $\begin{array}{l}\text { menganjurkan } \\
\text { kursus dan ikut } \\
\text { TOEFL }\end{array}$ \\
\hline R11 & $\begin{array}{l}\text { sangat } \\
\text { penting }\end{array}$ & pasif & $\begin{array}{l}\text { Gemar } \\
\text { membaca } \\
\text { tulisan dalam } \\
\text { bahasa inggris, } \\
\text { menonton } \\
\text { televisi siaran } \\
\text { dalam bahasa } \\
\text { inggris. }\end{array}$ & $\begin{array}{l}\text { latar belakang } \\
\text { pendidikan } \\
\text { dan kurangnya } \\
\text { tantangan } \\
\text { pekerjaan } \\
\text { yang } \\
\text { mengharuskan } \\
\text { mereka } \\
\text { berbahasa } \\
\text { Inggris }\end{array}$ & Belum Ada \\
\hline
\end{tabular}




\begin{tabular}{|l|l|l|l|l|l|}
\hline R12 & $\begin{array}{l}\text { sangat } \\
\text { penting }\end{array}$ & Aktif & $\begin{array}{l}\text { komunikasi } \\
\text { deng tamu } \\
\text { asing }\end{array}$ & $\begin{array}{l}\text { latar belakang } \\
\text { pendidikan } \\
\text { dan kurangnya } \\
\text { tantangan } \\
\text { pekerjaan } \\
\text { yang } \\
\text { mengharuskan } \\
\text { mereka } \\
\text { berbahasa } \\
\text { Inggris }\end{array}$ & ikut training \\
& & & & \\
& & & & \\
& & & & \\
\end{tabular}

Q= Pertanyaan

$\mathrm{R}=$ Responden

Selain dengan skala liker, diberikan pula pertanyaan terbuka yang membutuhkan jawaban informasi. Pengolahan data menggunakan metode triangulasi data, teknik pemeriksaan keabsahan data yang memanfaatkan sesuatu yang lain di luar data itu untuk keperluan pengecekan atau pembanding terhadap data itu. Untuk melakukan triangulasi (harus) digunakan triangulasi metode, triangulasi antar-peneliti (pengamat), triangulasi sumber data, dan triangulasi teori.

Prosedur sederhana triangulasi dalam penelitian ini adalah:

a) Seluruh jawaban terlebih dahulu dimasukkan ke dalam tiap pertanyaan.

b) Setiap pertanyaan dijadikan satu tema sebagai pengikat jawaban yang sama (bukan kesamaan kata/kalimat)

c) Selanjutnya dilakukan coding, klasifikasi dan reduksi data 
d) Jawaban yang sama dari tiap pertanyaan dikumpulkan jadi satu dengan berdasarkan berapa banyak responden menjawab hal yang sama

e) Jawaban berbeda tetap disimpan (tidak dibuang) karena berguna sebagai jawaban pembanding atau untuk mengetahui deviasi dari jawaban seragam

Pengolahan dengan triangulasi data diperoleh dari jawaban terbuka yang mereka berikan dalam pertanyaan esay, jawaban dapat dilihat sebagai berikut:

\begin{tabular}{|c|c|c|}
\hline NO & TEMA & KESIMPULAN JAWABAN \\
\hline 1. & $\begin{array}{l}\text { Pandangan tentang peran } \\
\text { Bahasa Inggris dalam } \\
\text { pelaksanaan tugas Anda } \\
\text { sehari-hari }\end{array}$ & Sebagian besar menjawab penting \\
\hline 2. & $\begin{array}{l}\text { Penguasaan Bahasa } \\
\text { Inggris, aktif atau pasif }\end{array}$ & Sebagian besar menjawab pasif \\
\hline 3. & $\begin{array}{l}\text { Usaha yang dilakukan } \\
\text { untuk meningkatkan } \\
\text { penguasaan bahasa } \\
\text { Inggris }\end{array}$ & $\begin{array}{l}\text { a. Kursus Bahasa } \\
\text { b. Menonton film berbahasa } \\
\text { Inggris } \\
\text { c. Berkomunikasi dengan keluarga } \\
\text { berbahasa Inggris } \\
\text { d. Membaca buku berbahasa } \\
\text { Inggris } \\
\text { e. Berbicara dengan orang asing }\end{array}$ \\
\hline 4. & $\begin{array}{l}\text { Kendala penyebab } \\
\text { staf/anak buah belum } \\
\text { dapat menguasai atau } \\
\text { berkomunikasi dalam } \\
\text { Bahasa Inggris }\end{array}$ & $\begin{array}{l}\text { a. Latar belakang pendidikan } \\
\text { b. Kurangnya tantangan pekerjaan } \\
\text { yang mengharuskan mereka } \\
\text { berbahasa Inggris }\end{array}$ \\
\hline
\end{tabular}




\begin{tabular}{|l|l|rl|}
\hline 5. & $\begin{array}{l}\text { Usaha yang dilakukan } \\
\text { untuk meningkatkan } \\
\text { penguasaan bahasa } \\
\text { Inggris staf/anak buah }\end{array}$ & a. & $\begin{array}{l}\text { Mengalokasikan anggaran untuk } \\
\text { peningkatan penguasaan bahasa } \\
\text { inggris melalui kursus }\end{array}$ \\
& b. $\begin{array}{l}\text { Memberi penugasan untuk } \\
\text { mengeksplor surat atau } \\
\text { dokumen berbahasa inggris }\end{array}$ \\
\hline
\end{tabular}

\section{Penutup}

1. Simpulan

Dari pembahasan di atas diperoleh simpulan bahwa hahasa Inggris sangat dibutuhkan bagi ASN namun dalam penerapannya masih harus terus diberikan motivasi oleh atasan atau sesama rekan kerja. Di samping itu penguasaan bahasa Inggris ASN sebagian besar masih pasif sehingga perlu ditinggkatkan mengingat upaya mengimplementasikan UU ASN dan SMART ASN sangat digiatkan oleh Pemerintah.

\section{Saran}

Saran yang dapat penulis berikan berdasarkan hasil penelitian adalah perlu adanya alokasi anggaran untuk peningkatan penguasaan bahasa Inggris melalui kursus bahasa Inggris dan kegiatan lain yang dapat mendorong ASN berkomunikasi dalam bahasa Inggris. Yag tak kalah penting adalah atasan memberi penugasan kepada staf/bawahan untuk melakukan tugas yang menantang dalam meningkatkan kemampuan berbahasa Inggris misalnya mengeksplor surat atau dokumen berbahasa Inggris. 


\section{BAGIAN III}

\section{PENINGKATAN KUALITAS TENAGA KEDIKLATAN DAN AKREDITASI LEMBAGA DIKLAT}

\section{A. Pendahuluan}

Kini kita tengah memasuki era yang menuntut perubahan dengan sangat cepat, bagi yang tidak ingin berubah maka akan tertinggal di semua lini kehidupan. Masyarakat menuntut kinerja pelayanan publik yang lebih baik, lebih cepat, lebih murah dan masih banyak lagi tuntutan lainnya. Selain tuntutan pelayanan publik, tak kalah pentingnya adalah tantangan eksternal yaitu globalisasi yang menuntut daya saing bangsa yang lebih tinggi di dalam kancah internasional. Keseriusan pemerintah sangat diperlukan dalam merespon perubahan dan dinamika lokal dan global di tataran dunia yang semakin kompleks. Berbagai upaya maksimal harus dilakukan seperti perbaikan penegakan hukum, mempersiapkan sumberdaya manusia (SDM) yang handal. Dan tidak ketinggalan juga termasuk di dalamnya adalah Reformasi Birokrasi. Hal ini dilakukan adalah demi terwujudnya tatanan 
berbangsa dan bernegara yang lebih baik (Good Governance), menjadi negara maju, transparan dan akuntabel.

Saat ini yang sedang gencar didengungkan adalah pemerintah merasa perlu mengusung istilah Revolusi Mental sebagai penyemangat perubahan yang melandasi pelaksanaan tugas aparatur. Revolusi adalah perubahan fundamental dalam struktur kekuatan atau organisasi yang terjadi dalam periode yang relatif singkat. Sedangkan kata Mental berhubungan dengan sesuatu yang terkait dengan jiwa, batin, dan rohani. Dalam Dictionary of Psychology (Chaplin, 2000) dapat kita temukan arti mental yaitu yang berkenaan dengan masalah "pikiran, akal, ingatan atau proses-proses yang berasosiasi dengan pikiran, akal, dan ingatan". Dengan demikian revolusi mental maksudnya adalah perubahan yang relatif cepat dalam cara berpikir, dalam merespon, bertindak dan bekerja.

Didasari oleh hal-hal tersebut di atas maka untuk peningkatan kualitas Aparatur Sipil Negara (ASN) diperlukan pembinaan yang berkesinambungan bagi ASN yang memiliki fungsi sebagai pelaksana kebijakan publik, pelayanan publik dan perekat serta pemersatu bangsa (Pasal 10 UU ASN). Reformasi birokrasi memerlukan birokrat-birokrat yang berpikir, inovatif, berani melakukan terobosan positif untuk perbaikan dan memiliki visi untuk memberikan pelayanan terbaik bagi masyarakat. Untuk itu diperlukan berbagai pendidikan dan pelatihan (Diklat) yang berkualitas yang dapat memfasilitasi pengembangan sumber daya aparatur pemerintah yang dapat membentuk birokrat seperti yang diharapkan di atas. Untuk menjamin terlaksananya pelaksanaan diklat yang berkualitas tersebut, diperlukan sebuah pengelolaan diklat yang berkualitas juga. Sejalan dengan itu pula, dilaksanakan akreditasi lembaga diklat dalam rangka untuk lebih meningkatkan mutu, efisiensi, efektifitas dan akuntabilitas diklat yang 
diselenggarakan oleh lembaga diklat pemerintah. Akreditasi oleh Lembaga Administrasi Negara tentu saja dilaksanakan untuk menjamin terlaksananya pengelolaan diklat yang berkualitas, dari berbagai segi misalnya terkait organisasi lembaga diklat yang mencakup dasar hukum, tenaga kediklatan, rencana strategis, fasilitas diklat, dan komite penjamin mutu diklat.

\section{B. Arah Peningkatan Kualitas Tenaga Kediklatan}

Undang-Undang Nomor 5 Tahun 2014 tentang ASN resmi diundangkan di lembaran negara dan mulai diberlakukan, maka undang-undang ini menggantikan Undang-Undang Nomor 8 Tahun 1974 juncto UndangUndang Nomor 43 Tahun 1999 tentang Pokok-Pokok Kepegawaian. Di antara perubahan mendasar dalam manajemen SDM aparatur adalah perubahan dari pendekatan personnel administration yang hanya berupa pencatatan administratif kepegawaian kepada human resource management. Pendekatan ini memandang sumber daya manusia aparatur sebagai aset negara yang harus dikelola, dihargai, dan dikembangkan dengan baik.

ASN sebagai sebuah profesi harus memiliki standar pelayanan profesi, nilai dasar, kode etik dan kode perilaku profesi, pendidikan dan pengembangan profesi, serta memiliki organisasi profesi yang dapat menjaga nilai-nilai dasar profesi. Untuk memperkuat sistem dalam birokrasi, ASN terdiri dari Pegawai Negeri Sipil (PNS) dan Pegawai Pemerintah dengan Perjanjian Kerja (PPPK) dengan basis utama kompetensi, kompetisi, dan kinerja. Perubahan mendasar lain, UU ASN ini juga akan mengubah dari pendekatan closed career system yang sangat berorientasi pada senioritas dan kepangkatan, kepada open career 
system yang mengedepankan kompetisi dan kompetensi ASN dalam promosi dan pengisian jabatan.

Tuntutan perubahan dengan sangat cepat membuat pemerintah merasa perlu mengusung semangat Revolusi Mental sehingga ASN diharapkan menerapkan semangat tersebut dalam pelaksanaan tugas. Salah satu fungsi penyelenggaraan pemerintahan yang dilakukan oleh ASN adalah pelayanan publik. Peraturan perundangan Indonesia telah memberikan landasan untuk penyelenggaraan pelayanan publik yang berdasarkan atas asas-asas umum pemerintahan yang baik. Dalam mewujudkan Reformasi Birokrasi dibutuhkan perbaikan dan kinerja pelayanan publik yang menjunjung tinggi mentalitas spiritual. Agar mampu melaksanakan fungsi pemerintah dengan baik maka aparatur harus profesional, tanggap, aspiratif terhadap tuntutan masyarakat yang dilayani.

Karena ASN meerupakan unsur sumberdaya manusia yang penting dalam pembangunan maka harus dapat diberdayakan dengan optimal. Menurut Wikipedia, sumberdaya manusia atau biasa disingkat menjadi SDM adalah potensi yang terkandung dalam diri manusia untuk mewujudkan perannya sebagai makhluk sosial yang adaptif dan transformatif yang mampu mengelola dirinya sendiri serta seluruh potensi yang terkandung di alam menuju tercapainya kesejahteraan kehidupan dalam tatanan yang seimbang dan berkelanjutan. Dalam pengertian praktis sehari-hari, SDM lebih dimengerti sebagai bagian integral dari sistem yang membentuk suatu organisasi.

SDM adalah manusia yang berada dan bekerja dalam suatu organisasi yang terdiri atas para pimpinan dan bawahan/staf pelaksana. Mereka adalah potensi manusiawi yang merupakan aset dan berfungsi sebagai modal yang menggerakkan organisasi dalam rangka mencapai tujuan. 
Basyir Barthos (2001) memaknai sumber daya manusia adalah penduduk dari suatu negara. Sumber daya manusia didefinisikan bukan dengan apa yang sumber daya manusia lakukan, tetapi apa yang sumber daya hasilkan (David Ulrich dalam Robert L. Malthis, 2001).

Dalam suatu organisasi modern, peran SDM selalu menjadi tumpuan dan sekaligus aset utama. Oleh karena itu, mereka harus selalu mendapat pengetahuan dan pemahaman masalah terkini dengan baik (Well Informed) mempunyai keterampilan yang serba bisa (Good Skill) dan tentu saja memiliki sikap dan perilaku yang baik (Good Attitude). Dengan SDM yang profesional, berpengetahuan dan berpandangan luas, terampil dan memiliki sikap dan perilaku baik, diharapkan tujuan organisasi dapat tercapai dengan baik sesuai yang diharapkan.

Dengan diberlakukannya UU ASN tersebut maka PNS akan menjadi suatu profesi. Untuk itu PNS sebagai bagian dari ASN harus menunjukkan pelayanan yang profesional sebagaimana UU 5 Tahun 2014 Pasal 3. Menurut Sanusi, et. al dalam Soetjipto (2000) bahwa ciri-ciri utama suatu profesi itu antara lain suatu jabatan yang memiliki fungsi dan signifikansi sosial yang menentukan (krusial) dan jabatan yang menuntut keterampilan/keahlian tertentu. Selain itu dalam memberikan layanan kepada masyarakat anggota profesi itu berpegang teguh pada kode etik yang timbul yang dikontrol oleh organisasi profesi. Ini berarti bahwa pekerjaan yang bersifat profesional adalah pekerjaan yang hanya dapat dilakukan oleh mereka yang khusus dipersiapkan untuk itu dan bukan pekerjaan yang dilakukan oleh mereka yang karena tidak memperoleh pekerjaan yang lain. 
Menurut Affandi (2002) dalam The Little Life Gallery Blog, ada empat ciri-ciri yang bisa ditenggarai sebagai petunjuk atau indikator untuk melihat tingkat profesionalitas seseorang yaitu:

1. Penguasaan ilmu pengetahuan seseorang di bidang tertentu, dan ketekunan mengikuti perkembangan ilmu yang dikuasai.

2. Kemampuan seseorang dalam menerapkan ilmu yang dikuasai, khususnya yang berguna bagi kepentingan sesama.

3. Ketaatan dalam melaksanakan dan menjunjung tinggi etika keilmuan, serta kemampuannya untuk memahami dan menghormati nilai-nilai sosial yang berlaku dalam lingkungannya.

4. Besarnya rasa tanggung jawab terhadap Tuhan, bangsa dan negara, masyarakat, keluarga serta diri sendiri atas segala tindak lanjut dan perilaku dalam mengemban tugas berkaitan dengan penugasan penerapan bidang ilmu yang dimilliki.

Dari apa yang dijelaskan oleh Sanusi dan Affandi di atas dapat disimpulkan bahwa seorang ASN seyogyanya menjunjung tinggi profesionalitas kerja mereka. Salah satu alasannya karena sebagai aparatur ASN memiliki fungsi dan signifikansi sosial yang menentukan (krusial). Bila dihubungkan dengan dunia diklat, ASN dikenal dengan istilah Tenaga Kediklatan. Betapa tidak, berjalannya diklat sebagai sarana pembelajaran bagi peserta diklat akan sangat terbantu dengan adanya Tenaga Kediklatan. Para peserta mengharapkan diklat yang mereka ikuti akan memberikan hasil dan manfaat yang signifikan dengan kesenjangan kompetensi yang dirasakan. 


\section{Tenaga Kediklatan}

Tenaga Kediklatan menjadi salah satu bidang pembangunan yang menjadi perhatian pemerintah. Salah satu aspek yang menjadi pertimbangan adalah bahwa pelaksanaan program pembangunan aparatur negara masih menghadapi berbagai permasalahan dalam penyelenggaraan negara dan pemerintahan. Berbagai penilaian negatif terhadap birokrasi tidak hanya muncul dari dalam negeri, tetapi juga dari lingkungan global yang memiliki keterkaitan dengan Indonesia terutama sektor perekonomian.

Indikasi ini ditunjukkan dengan penilaian yang menempatkan posisi Indonesia dalam posisi yang tidak menguntungkan dibandingkan dengan posisi negara-negara lain dalam lingkup global. Birokrasi pemerintah dipandang tidak efisien, banyak diwarnai dengan praktek korupsi, kolusi dan nepotisme, tidak mampu memberikan kebijakan yang memfasilitasi serta lambat memberikan respon terhadap kebutuhan masyarakat dan sektor swasta. Birokrasi memiliki peran penting dalam upaya mewujudkan governance.

Peran birokrasi dalam kaitan iniadalah membangun tradisi dan institusi yang melaksanakan kewenangan melalui proses politik pemilihan pemerintah, perumusan kebijakan yang efektif, penghormatan terhadap warga negara dan institusi lain yang ikut membangun perekonomian dan sosial dalam negara. Reformasi birokrasi tidak cukup hanya dengan memperbaiki berbagai sistem yang berlaku saat ini, tetapi juga harus menyentuh para birokrat yang menjalankan sistem tersebut. Reformasi birokrasi memerlukan birokrat-birokrat yang berpikir, inovatif, berani melakukan terobosan positif untuk perbaikan dan memiliki visi untuk memberikan pelayanan terbaik bagi masyarakat. Untuk itu diperlukan 
berbagai diklat yang berkualitas yang dapat memfasilitasi pengembangan sumber daya aparatur pemerintah yang dapat membentuk birokrat seperti yang diharapkan di atas. Untuk menjamin terlaksananya pelaksanaan diklat yang berkualitas tersebut, diperlukan sebuah pengelolaan diklat yang berkualitas juga.

Setiap Pegawai ASN memiliki hak dan kesempatan untuk mengembangkan kompetensi antara lain melalui: pendidikan dan pelatihan, seminar, kursus, dan penataran. Pengembangan kompetensi ini harus dievaluasi oleh Pejabat yang berwenang dan digunakan sebagai salah satu dasar dalam pengangkatan jabatan dan pengembangan karier. Selain itu pengembangan kompetensi ini wajib disusun dalam rencana pengembangan kompetensi tahunan dalam rencana kerja anggaran tahunan instansi.

Di dalam UU ASN dijelaskan tentang Hak dan Kesempatan bagi ASN baik PNS maupun PPPK mengikuti pengembangan kompetensi, yaitu:

1. Memiliki hak dan kesempatan yang sama untuk diikutsertakan dalam pengembangan kompetensi, dengan memperhatikan hasil penilaian kinerja dan penilaian kompetensi yang bersangkutan.

2. Pengembangan kompetensi sebagaimana dimaksud dilakukan paling kurang 80 jam pelajaran dalam 1 (satu) tahun.

Jenis pengembangan dapat dilaksanakan melalui:

1. Pendidikan Formal

a. Pengembangan kompetensi dalam bentuk pendidikan dilakukan untuk meningkatkan pengetahuan dan keahlian PNS melalui pendidikan formal sesuai dengan peraturan perundang-undangan. 
b. Pengembangan kompetensi dalam bentuk pendidikan formal sebagaimana dimaksud diatas dilaksanakan dengan pemberian tugas belajar.

c. Pemberian tugas belajar sebagaimana dimaksud diberikan dalam rangka memenuhi kebutuhan standar kompetensi jabatan dan pengembangan karir.

Untuk tenaga kediklatan, yang terdiri dari Pimpinan Penyelenggara Diklat, Penyelenggara Diklat dan widyaiswara maka harus dimotivasi untuk dapat melanjutkan pendidikan formal setidaknya ke tingkat strata dua mengingat tantangan dan tuntutan publik ke depan yang akan lebih berat. Terkait dengan widyaiswara, untuk pendidikan formal diharapkan sudah memasuki jenjang strata tiga, karena peserta diklat yang dihadapi akan lebih banyak yang berusia muda dan berwawasan luas.

2. Pelatihan

a. Pengembangan kompetensi dalam bentuk pelatihan dilakukan melalui jalur pelatihan klasikal dan non-klasikal.

b. Pengembangan kompetensi dalam bentuk pelatihan klasikal sebagaimana dimaksud, dilakukan melalui proses pembelajaran tatap muka di dalam kelas, melalui pelatihan, seminar, kursus, penataran, sosialisasi, workshop, semiloka, sekolah kader serta bentuk lain yang sejenis.

c. Pengembangan kompetensi dalam bentuk pelatihan non-klasikal sebagaimana dimaksud dilakukan melalui e-learning, bimbingan di tempat kerja, pelatihan jarak jauh, magang dan pertukaran antara PNS dan pegawai swasta serta bentuk lain yang sejenis. 
Untuk tenaga kediklatan maka diharapkan sudah mengikuti berbagai pelatihan teknis yang dapat meningkatkan keterampilan mereka. Para pengelola diklat yang memegang kebijakan dalam pengelolaan diklat diharapkan telah mengikuti Diklat Teknis Pengelolaan Diklat (Management of Training/MOT), sedangkan para penyelenggara diklat yang bertugas menjadi panitia penyelenggara diharapkan telah mengikuti Diklat Teknis bagi Penyelenggara Diklat (Training Officer Course/TOC). Bagi widyaiswara harus mengikuti sejumlah Training of Trainers (TOT) demi meningkatkan kompetensi mendidik, mengajar dan melatih (dikjartih).

Dalam Peraturan Kepala Lembaga Administrasi Negara Nomor 25 tahun 2015 tentang Pedoman Akreditasi Lembaga Pendidikan dan Pelatihan Pemerintah disebutkan beberapa kriteria penilaian terhadap tenaga kediklatan.

Penilaian terhadap pengelola diklat meliputi:

1. Pendidikan formal, kompetensi kepemimpinan, kompetensi mengelola Diklat, dan pengalaman mengelola diklat;

2. Penilaian terhadap pendidikan formal adalah kesesuaian pendidikan formal dengan bidang kediklatan;

3. Penilaian kompetensi kepemimpinan adalah jumlah Pengelola Diklat yang telah mengikuti Diklat Kepemimpinan tertentu dengan dibuktikan melalui Surat Tanda Tamat Pendidikan dan Pelatihan;

4. Penilaian kompetensi mengelola diklat adalah jumlah pengelola Diklat yang telah mengikuti Diklat Management of Training (MOT) dengan dibuktikan melalui sertifikat Diklat MOT;

5. Penilaian pengalaman adalah jumlah pengalaman mengelola Diklat Prajabatan dan/atau Diklat Kepemimpinan tertentu yang 
telah dilaksanakan yang dibuktikan melalui laporan penyelenggaraan Diklat Prajabatan dan/atau Diklat Kepemimpinan tertentu.

Penilaian terhadap Widyaiswara atau tenaga pengajar meliputi:

1. Pendidikan formal, kompetensi, spesialisasi, pengalaman mengajar dan kesinambungan pengembangan bidang keahlian pada Diklat prajabatan dan/atau Diklat kepemimpinan tertentu

2. Penilaian terhadap pendidikan formal adalah kesesuaian pendidikan formal widyaiswara atau tenaga pengajar dengan mata Diklat yang diampu pada Diklat Prajabatan dan/atau Diklat Kepemimpinan tertentu;

3. Penilaian kompetensi Widyaiswara atau tenaga pengajar adalah jumlah Widyaiswara yang telah mengikuti Training of Trainers (TOT) dengan dibuktikan melalui sertifikat;

4. Penilaian terhadap spesialisasi adalah relevansi bidang spesialisasi Widyaiswara atau tenaga pengajar dengan mata Diklat yang diampu pada Diklat Prajabatan dan/atau Diklat Kepemimpinan tertentu;

5. Penilaian terhadap pengalaman mengajar adalah tingkat frekuensi mengajarkan mata diklat yang diampu pada Diklat Prajabatan dan/atau Diklat Kepemimpinan tertentu;

6. Penilaian terhadap kesinambungan pengembangan bidang keahlian adalah program pengembangan kompetensi yang dimiliki atau dilaksanakan oleh Widyaiswara atau tenaga pengajar sesuai dengan mata Diklat yang diampu.

Penilaian terhadap penyelenggara Diklat meliputi:

1. Pendidikan formal, kompetensi penyelenggara, dan pengalaman menyelenggarakan diklat; 
2. Penilaian terhadap pendidikan formal adalah kesesuaian pendidikan formal penyelenggara dengan bidang kediklatan;

3. Penilaian kompetensi Penyelenggara Diklat adalah jumlah penyelenggara Diklat yang telah mengikuti Training Officer Course (TOC) dengan dibuktikan melalui sertifikat;

4. Penilaian pengalaman menyelenggarakan diklat adalah jumlah pengalaman menyelenggarakan Diklat Prajabatan dan/atau Diklat Kepemimpinan tertentu yang telah dilaksanakan yang dibuktikan melalui laporan penyelenggaraan Diklat Prajabatan dan/atau Diklat Kepemimpinan tertentu.

\section{Penutup}

Manajemen ASN diarahkan untuk terselenggaranya tugas-tugas umum pemerintahan dan pembangunan dan untuk mewujudkan tugas-tugas tersebut maka dibutuhkan ASN yang profesional, jujur, adil dan bertanggung jawab melalui pembinaan karier dan prestasi kerja yang lebih dititikberatkan pada prestasi kerja. Adapun sosok ASN yang diharapkan dalam upaya perjuangan mencapai tujuan nasional adalah ASN yang memiliki kompetensi, penuh kesetiaan dan ketaatan kepada Pancasila, Undang- Undang Dasar 1945, dan Negara Kesatuan Republik Indonesia, profesional, berbudi pekerti luhur, berdaya guna, berhasil guna, sadar akan tanggung jawabnya sebagai unsur aparatur negara, abdi masyarakat dan abdi negara di dalam negara hukum yang demokratis.

Pembangunan yang sekarang giat dilaksanakan membutuhkan SDM yang aparatur dan peningkatan kualitas pelayanan publik. Indikator peningkatan kualitas pelayanan publik merupakan suatu upaya untuk meningkatkan kualitas pelayanan publik pada masing-masing instansi 
pemerintah secara berkala sesuai kebutuhan dan harapan masyarakat yang menginginkan pelayanan yang efektif, efisien, lebih cepat dan murah. Keberadaan ASN dalam Negara Kesatuan Republik Indonesia sangat strategis karena ASN adalah penyelenggara tugas-tugas umum pemerintahan dan pembangunan. Oleh karena itu pembinaan dan peningkatan kualitas ASN harus dikedepankan sebagai upaya sadar sebagaimana yang telah diamanahkan oleh Undang-undang.

Untuk mendukung hal tersebut di atas, dibutuhkan diklat yang berkualitas yang dapat meningkatkan pengetahuan, keterampilan dan sikap ASN. Dalam dunia kediklatan, unsur SDM yang berperan disebut tenaga kediklatan yang terdiri dari pengelola, penyelenggara dan widyaiswara. Pengelolaan diklat yang berkualitas tak akan terlepas dari profesionalitas tenaga kediklatan tersebut. Untuk menjamin terlaksananya diklat yang bermutu, efektif dan efisien, dilaksanakanlah akreditasi lembaga diklat oleh instansi Pembina diklat, yaitu Lembaga Administrasi Negara. Terkait tenaga kediklatan, banyak hal yang harus diperhatikan dan dilaksanakan sehingga tenaga kediklatan baik di Pusdiklat Tenaga Administrasi maupun Balai Diklat keagamaan dapat melaksanakan diklat dengan lebih professional dan dapat mencapai kriteria akreditasi lembaga diklat yang baik. 


\section{BAGIAN IV \\ URGENSI INTEGRITAS DALAM PELAKSANAAN TUGAS}

\section{A. Pendahuluan}

Masih terdengar opini masyarakat yang memberikan predikat dan citra buruk terkait penyelewengan, penyimpangan dan penyalahgunaan keuangan negara atau wewenang dengan tindakan Korupsi, Kolusi dan Nepotisme (KKN) di setiap lini organisasi pemerintahan. Fenomena tersebut masih memerlukan upaya penanggulangan dari berbagai pendekatan oleh semua pihak, sebab jika tidak maka keruguan negara dalam penyelenggaraan pemerintahan akan semakin meluas dan memburuk.

Pembentukan mental yang baik dan integritas yang tinggi pada diri PNS memerlukan pembentukan kesadaran diri, karakter, dan kemampuan mengontrol diri sendiri. Masalah ini tidak dapat diatasi sendiri oleh satu individu atau satu lembaga saja, namun semua pihak harus bahu membahu melaksanakan ini. 
Salah satu akar permasalahan korupsi adalah karena rendahnya integritas baik di tingkat organisasi maupun individu. Integritas menjadi hal yang perlu ditanamkan sejak dini untuk mencegah korupsi. Tanpa perbaikan pada integritas, sebaik apapun sistem akan selalu muncul kolusi. Kehadiran integritas di tingkat individu, organisasi dan nasional merupakan cara yang baik untuk mencegah terjadinya korupsi. Di Indonesia upaya tersebut sudah muncul, diinisiasi oleh berbagai Kementerian/Lembaga. Untuk itu, dibutuhkan perangkat yang mampu membantu Kementerian/Lembaga untuk memetakan persoalan integritas, mengembangkan program pencegahan dan penindakan, serta mengukur keberhasilan strategi pencegahan korupsi. Maka dari itu, dilaksanakanlah penelitian Integritas kepada peserta pendidikan dan pelatihan pengadaan barang/jasa pemerintah pada Kementerian Agama baik pusat maupun daerah.

Tujuan pelaksanaan penelitian ini bertujuan untuk memetakan kondisi integritas dan capaian upaya pencegahan korupsi pada Kementerian Agama. Tujuan dari diadakannya penelitian ini adalah:

1. Menyajikan indeks integritas pada Kementerian Agama;

2. Menyajikan gambaran umum permasalahan integritas yang dihadapi Kementerian Agama.

Manfaat dari hasil kegiatan penelitian ini antara lain:

1. Sebagai alat untuk mengidentifikasi prioritas area perbaikan yang rentan terhadap korupsi, sebagai dasar perbaikan program pencegahan korupsi di Kementerian Agama;

2. Memberikan capaian upaya pencegahan korupsi dan aktivitas antikorupsi yang sudah dilakukan di Kementerian Agama; 
3. Mendorong peran serta pegawai internal Kementerian Agama dalam peningkatan integritas dan meningkatkan kepercayaan (trust) publik pada Kementerian Agama.

\section{B. Metode}

Metode penelitian integritas adalah kualitatif dengan melakukan pengumpulan data yang dilakukan dengan cara memberi seperangkat pernyataan tertulis (kuesioner) kepada reseponden. Data yang diperoleh kemudian dikumpulkan dan dianalisis. Populasi dan sampel (sasaran penelitian) para peserta Pendidikan dan Pelatihan Pengadaan Barang/Jasa Pemerintah tahun 2019 sebanyak 29 responden.

\section{Hasil dan Pembahasan}

\section{Internalisasi Nilai Integritas}

Jika ditanya, "Apa sih integritas itu?" atau "Bagaimana membedakan antara orang yang berintegritas atau tidak?", maka kita sering menjawab bahwa secara mudah, jika seseorang melakukan sesuatu yang berbeda dengan kata hatinya, maka ia tidak berintegritas. Hal itulah yang seringkali kita yakini bukan? Lalu apakah sebenarnya integritas tersebut? Berikut ini akan dibahas tentang integritas yang dikutip dari beberapa ahli sebagai berikut.

Kata "integritas" berasal dari kata sifat Latin integer (utuh, lengkap) Dalam konteks ini, integritas adalah rasa batin "keutuhan" yang berasal dari kualitas seperti kejujuran dan konsistensi karakter. Dengan demikian, seseorang dapat menghakimi bahwa orang lain "memiliki integritas" sejauh 
bahwa mereka bertindak sesuai dengan nilai dan prinsip keyakinan mereka.

Filsuf Herb Shepherd (Antonius, 2002:135-136) menyebutkan integritas diri sebagai kesatuan yang mencakup empat nilai, yaitu perspektif (spiritual), otonomi (mental), keterkaitan sosial, dan tonus (fisik). Kata integritas juga berasal dari bahasa Inggris yakni integrity. Menurut Wikipedia Integrity is a concept of consistency of actions, values, methods, measures, principles, expectations, and outcomes. In ethics, integrity is regarded as the honesty and truthfulness or accuracy of one's actions. Dalam pengertian tersebut, arti integritas dihubungkan dengan kepribadian seseorang yaitu jujur dan utuh. Ada juga yang mengartikan integritas sebagai keunggulan moral dan menyamakan integritas sebagai "jati diri". Integritas juga diartikan sebagai bertindak konsisten sesuai dengan nilai-nilai dan kode etik. Dengan kata lain integritas diartikan sebagai "satunya kata dengan perbuatan". Paul J. Meyer dalam Nurmaida (2016:3) menyatakan bahwa "integritas itu nyata dan terjangkau dan mencakup sifat seperti: bertanggung jawab, jujur, menepati kata-kata, dan setia. Jadi, saat berbicara tentang integritas tidak pernah lepas dari kepribadian dan karakter seseorang, yaitu sifat-sifat seperti dapat dipercaya, komitmen, tanggung jawab, kejujuran, kebenaran, dan kesetiaan.

Hal yang kurang lebih sama dapat kita lihat juga dalam negara lain yang memiliki kemantapan dan kestabilan yang semakin baik dalam berbagai bidang kehidupan. Atau juga dalam lembaga lain, seperti lembaga keagamaan dan lembaga swasta lain yang memiliki kemantapan dan kestabilan yang semakin baik serta mampu bertahan dalam berbagai kondisi sosial masyarakat dan bahkan dunia sekali pun. Semua itu pastilah terkait karena integritas yang dimiliki oleh para pemimpin dari lembaga itu. 
Integritas diri yang dimiliki oleh seseorang, terutama oleh seorang pemimpin, memiliki dampak sangat besar bagi kehidupan yang menyertainya. Mengecek integritas diri dapat juga meliputi pengukuran apakah seorang pemimpin dapat memanfaatkan wewenangnya dan mengambil risiko untuk membuat tindakan perbaikan dari yang populer sampai yang tidak populer sekalipun (Eileen Rachman, 2006:43).

Para tokoh itu, walau dengan istilah yang agak berbeda, namun samasama menyebutkan hal yang merupakan unsur penting dalam diri manusia, yakni fisik, sosial, dan mental-spiritual. Unsur penting tersebut merupakan dimensi dasar diri manusia. Integritas diri dilihat sebagai keterpaduan sinergis dan saling mendukung antara ketiga dimensi dasar tersebut dalam kehidupan seseorang. Ketiganya berkembang secara seimbang sehingga dapat saling mendukung dalam menjalani kehidupan secara lebih manusiawi. Inilah pengertian yang lebih luas tentang integritas diri.

Menurut Dwi Wahyudi dalam artikel DJKN, di dalam Kamus Kompetensi Kementerian Keuangan RI integritas adalah mempertahankan tingkat kejujuran dan etika yang tinggi dalam perkataan dan tindakan sehari-hari. Dengan demikian integritas dapat dicirikan (Karakteristik Integritas) melalui:

1. Ketulusan. Seorang pemimpin yang berintegritas biasanya mempunyai sikap yang tulus. Ketulusan menurut Kamus Besar Bahasa Indonesia (KBBI, 2007: 1219) adalah kesungguhan dan kebersihan (hati). Ketulusan adalah perilaku tanpa kepura-puraan ataupun kesan yang palsu.

2. Konsistensi. Seorang pemimpin jika ingin berhasil dalam memimpin sebuah organisasi harus mempunyai sikap konsisten. 
Integritas dibangun seumur hidup, sekali ada kecacatan dalam perbuatan yang mencoreng integritasnya, integritas dari seorang pemimpin itu akan menjadi cacat permanen. Konsistensi seorang pemimpin seringkali diuji dengan konsistensinya dalam menegakkan sanksi hukuman kepada anak buahnya. Walaupun dia terkenal mempunyai integritas yang tinggi, di saat ada pelanggaran yang sama pada anak buahnya yang baru dan senior, hukumannya justru dibedakan. Ketidakadilan yang dilakukannya sudah jelas menodai integritasnya yang dibangunnya bertahun-tahun. c) Keteguhan hati. Keteguhan hati merupakan karakteristik yang melekat pada pemimpin berintegritas. Dalam masa-masa normal, biasanya pemimpin yang dikenal berintegritas jika dipandang oleh orang awam terlihat mempunyai keteguhan hati. Namun pada masa-masa sulit, keteguhan hati dari pemimpin yang dipandang berintegritas tinggi akan diuji, apakah pemimpin tersebut benar-benar berintegritas atau tidak. Pada masa-masa sulit, pemimpin yang mempunyai integritas lemah tidak bisa membangun organisasinya ataupun bertahan dalam situasi yang penuh tantangan. d) Menjadi seorang yang mampu bertahan sampai akhir. Integritas seseorang juga dapat dilihat dari kesetiaannya terhadap pekerjaan ataupun perjuangan. Contohnya adalah seorang atlet bulutangkis kemungkinan besar akan kalah karena sudah tertinggal jauh dalam perolehan skor dari lawannya, tetapi tetap bermain dengan semangat dan penuh optimis sampai akhir pertandingan.

Integritas juga memiliki fungsi yaitu: 1) Integritas sebagai keterampilan. Integrity is a skill bermakna bahwa integritas adalah sesuatu yang bisa dibangun dan dipelajari sepanjang waktu. 2) Integritas sebagai pedoman. Integrity is a guideline bahwa integritas dijadikan acuan dalam mengambil keputusan berdasarkan kebenaran dan kejujuran. 3) Integritas sebagai bangunan yang kokoh. Integritas adalah sesuatu yang dibangun dan 
dipelihara sepanjang hidup. Pembangunan integritas dimulai sejak muda dengan pondasi yang kuat dan mendalam. Seperti halnya bangunan yang kokoh dimulai dibangun dari pondasi yang kokoh, tembok dan kerangka bangunan, pintu, jendela, dan terakhir atap. 4) Integritas sebagai tanaman. Integritas juga seperti halnya tanaman. Tanaman ditanam dari sebuah benih, disirami setiap hari, dipupuk dengan terakhir, sampai akhirnya berbunga dan menghasilkan buah.

Integritas adalah sebuah konsep dari tindakan konsekuensi, nilai, metode, prinsip, ekspektasi dan pengeluaran. Dalam kebudayaan, integritas digambarkan sebagai kejujuran dan kepercayaan atau tindakan yang akurat. Integritas dapat dikatakan sebagai lawan dari hipokrits. Kata integritas berasal dari bahasa latin yaitu integer (keseluruhan, selesai). Dalam konteks ini, integritas merupakan perasaan yang paling luar dari keseluruhan seperti karakter jujur dan konsisten. Seseorang mungkin dapat menilai orang lain yang memiliki integritas. Untuk membuktikannya mereka berperilaku sesuai dengan nilai, keyakinan, dan prinsip yang mereka pegang. Sedangkan menurut Lilik Agung (2007:12), integritas sering diartikan sebagai satunya pikiran, perkataan dan perbuatan. Jika merujuk pada kata asalnya, yaitu integer dan integration, maka integritas mempunyai makna berbicara dengan utuh dan sepenuh-penuhnya. Andreas Harefa (2009:10) dalam bukunya Manusia Pembelajar, dalam buku tersebut dijelaskan salah satu definisi integritas adalah "maining social, ethical, and organizational norm, firmly adhering to code of conduct anda atichal principle". Dengan pengertian tersebut integritas diterjemahkan menjadi tiga tindakan kunci (key action) yang dapat diamati (observable). Pertama, menunjukkan kejujuran (demonstrate honesty), yaitu bekerja dengan orang lain secara jujur dan benar, menyajikan informasi secara lengkap dan akurat. Kedua, memenuhi komitmen (keeping commitment), 
yaitu melakukan apa yang telah dijanjikan, tidak membocorkan rahasia. Ketiga berperilaku secara konsisten (behave consistently), yaitu menunjukkan tidak adanya kesenjangan antara kata dan perbuatan. Dari beberapa pengertian tersebut dapat disimpulkan bahwa integritas adalah kualitas diri positif yang dimiliki seseorang (jujur, dapat dipercaya dan tidak pernah ingkar janji).

Mengapa pelayan masyarakat harus memiliki integritas dan komitmen? Pelayan publik dalam melaksanakan tugas dan fungsinya perlu memiliki integritas dan komitmen agar mampu bekerja secara profesional. Mengapa demikian? Karena integritas adalah sebuah konsep konsistensi tindakan, nilai-nilai, metode, langkah-langkah, prinsip, harapan, dan hasil. Dalam etika, integritas dianggap sebagai kejujuran dan kebenaran yang merupakan kata kerja atau akurasi dari tindakan seseorang. Integritas dapat dianggap sebagai kebalikan dari kemunafikan, yang menganggap konsistensi internal sebagai suatu kebajikan, dan menyarankan bahwa pihak-pihak yang memegang nilai-nilai yang tampaknya bertentangan harus menerima perbedaan atau mengubah keyakinan mereka.

\section{Hasil Penelitian}

Variabel Indeks Penilaian Integritas ini memiliki 22 variabel yang membentuk keempat dimensi penilaian, yang meliputi:

1. Budaya organisasi dan sistem antikorupsi, mencakup adanya transparansi, penolakan terhadap suap, tidak adanya korupsi kolusi dan nepotisme dalam menjalankan tugas, keberadaan calo/perantara/biro jasa, suasana yang aman bagi pelapor praktik korupsi, sanksi bagi para pelaku pelanggaran dan korupsi, system pencegahan korupsi; 
2. Integritas kerja terkait Pengelolaan SDM, yang mencakup seleksi penerimaan pegawai dan praktik KKN dalam peningkatan karir pegawai;

3. Integritas kerja dan pelaksanaan anggaran, yang mencakup pengelolaan perjalanan dinas, anggaran pengadaan barang dan jasa, biaya penunjang pelaksanaan kegiatan, dan bukti transaksi;

4. Integritas kerja dan kesesuaian perintah atasan dengan aturan dan norma yang mencakup tanggung jawab atasan, perintah kerja atasan, perlakuan atasan, kode etik dan aturan disiplin organisasi.

Penelitian integritas dilakukan terhadap sejumlah responden yang merupakan peserta pelatihan pengadaan barang/jasa pemerintah sebanyak 29 orang dengan profil sebagai berikut:

Tabel 1. Profil Responden Penelitian Integritas

\begin{tabular}{|l|l|l|l|}
\hline No & \multicolumn{1}{|c|}{ Kategori } & \multicolumn{2}{|c|}{ Persentase } \\
\hline 1 & Jenis Kelamin & $6,8 \%$ & Laki-laki \\
\cline { 3 - 4 } & & $93 \%$ & Perempuan \\
\hline 2 & Usia & $15 \%$ & $>40$ tahun \\
\cline { 3 - 4 } & & $14 \%$ & $<40$ tahun \\
\hline 3 & Pendidikan & $6,8 \%$ & S3 \\
\cline { 3 - 4 } & & $17,2 \%$ & S2 \\
\cline { 3 - 4 } & & $72 \%$ & S1 \\
\cline { 3 - 4 } & & $3,4 \%$ & SLTA \\
\hline 4 & Jabatan & $28 \%$ & Eselon IV \\
\cline { 3 - 4 } & & &
\end{tabular}




\begin{tabular}{|l|l|l|l|}
\cline { 3 - 4 } \multicolumn{1}{l|}{} & & $10 \%$ & JFT \\
\cline { 3 - 4 } & & $62 \%$ & Pelaksana \\
\hline 5 & Unit Kerja & $27 \%$ & Kankemenag \\
\hline & & $62 \%$ & Kanwil \\
\hline & & $10 \%$ & Pusdiklat \\
\hline
\end{tabular}

Penelitian menggunakan kuesioner menunjukkan hasil sebagai berikut:

Tabel 2. Hasil Penelitian

\begin{tabular}{|c|c|c|c|c|c|}
\hline \multirow[b]{2}{*}{ NO } & \multirow[b]{2}{*}{ RINCIAN PERTANYAAN } & \multicolumn{4}{|c|}{ KUALITAS INTEGRITAS (\%) } \\
\hline & & $\begin{array}{l}\text { Sangat } \\
\text { Setuju }\end{array}$ & Setuju & $\begin{array}{l}\text { Tidak } \\
\text { Setuju }\end{array}$ & $\begin{array}{l}\text { Sangat } \\
\text { Tidak } \\
\text { Setuju }\end{array}$ \\
\hline 1 & Budaya Organisasi dan Siste & Anti Kc & rupsi & & \\
\hline & $\begin{array}{l}\text { a. Petugas/pegawai/pejab } \\
\text { at di instansi saya } \\
\text { menangani tugas- } \\
\text { tugas/pekerjaan mereka } \\
\text { secara terbuka dan } \\
\text { dapat diakses oleh } \\
\text { semua pihak yang } \\
\text { membutuhkan }\end{array}$ & 24.1 & 72.4 & 0.0 & 3.4 \\
\hline
\end{tabular}




\begin{tabular}{|c|c|c|c|c|c|}
\hline \multirow[b]{2}{*}{ NO } & \multirow[b]{2}{*}{ RINCIAN PERTANYAAN } & \multicolumn{4}{|c|}{ KUALITAS INTEGRITAS (\%) } \\
\hline & & $\begin{array}{l}\text { Sangat } \\
\text { Setuju }\end{array}$ & Setuju & $\begin{array}{l}\text { Tidak } \\
\text { Setuju }\end{array}$ & $\begin{array}{l}\text { Sangat } \\
\text { Tidak } \\
\text { Setuju }\end{array}$ \\
\hline & $\begin{array}{l}\text { b. Petugas/pegawai/pejab } \\
\text { at di instansi saya } \\
\text { menangani tugasnya } \\
\text { tanpa menerima } \\
\text { pemberian } \\
\text { (uang/hadiah/hiburan/ } \\
\text { dan kemudahan/ } \\
\text { fasilitas atau janji) }\end{array}$ & 34.5 & 65.5 & 0.0 & 0.0 \\
\hline & $\begin{array}{l}\text { c. Petugas/pegawai/pejab } \\
\text { at di instansi saya } \\
\text { melaksanakan tugas- } \\
\text { tugas/pekerjaan } \\
\text { memberikan perlakuan } \\
\text { yang sama tanpa } \\
\text { membedakan daerah } \\
\text { asal (kesukuan), sekolah } \\
\text { asal, kekerabatan, } \\
\text { agama }\end{array}$ & 37.9 & 58.6 & 3.4 & 0.0 \\
\hline & $\begin{array}{l}\text { d. Petugas/pegawai/pejab } \\
\text { at di instansi saya } \\
\text { melaksanakan tugasnya } \\
\text { sesuai dengan }\end{array}$ & 31.0 & 62.1 & 6.9 & 0.0 \\
\hline
\end{tabular}




\begin{tabular}{|c|c|c|c|c|c|}
\hline \multirow[b]{2}{*}{ NO } & \multirow[b]{2}{*}{ RINCIAN PERTANYAAN } & \multicolumn{4}{|c|}{ KUALITAS INTEGRITAS (\%) } \\
\hline & & $\begin{array}{l}\text { Sangat } \\
\text { Setuju }\end{array}$ & Setuju & $\begin{array}{l}\text { Tidak } \\
\text { Setuju }\end{array}$ & $\begin{array}{l}\text { Sangat } \\
\text { Tidak } \\
\text { Setuju }\end{array}$ \\
\hline & $\begin{array}{l}\text { ketentuan yang berlaku } \\
\text { tanpa menawarkan/ } \\
\text { mengajak untuk } \\
\text { membantu secara illegal }\end{array}$ & & & & \\
\hline & $\begin{array}{l}\text { e. Pelapor kejadian } \\
\text { korupsi dan pelapor } \\
\text { terkait pelanggaran } \\
\text { kepentingan } \\
\text { publik/masyarakat } \\
\text { dilindungi secara efektif } \\
\text { di instansi saya }\end{array}$ & 34.5 & 58.6 & 6.9 & 0.0 \\
\hline & 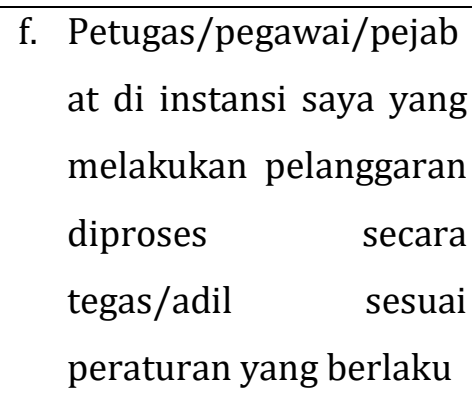 & 31.0 & 58.6 & 3.4 & 0.0 \\
\hline & $\begin{array}{l}\text { g. Sistem pencegahan } \\
\text { korupsi di internal di } \\
\text { instansi saya telah } \\
\text { berjalan secara efektif }\end{array}$ & 27.6 & 58.6 & 10.3 & 3.4 \\
\hline
\end{tabular}




\begin{tabular}{|c|c|c|c|c|c|}
\hline \multirow[b]{2}{*}{ NO } & \multirow[b]{2}{*}{ RINCIAN PERTANYAAN } & \multicolumn{4}{|c|}{ KUALITAS INTEGRITAS (\%) } \\
\hline & & $\begin{array}{l}\text { Sangat } \\
\text { Setuju }\end{array}$ & Setuju & $\begin{array}{l}\text { Tidak } \\
\text { Setuju }\end{array}$ & $\begin{array}{l}\text { Sangat } \\
\text { Tidak } \\
\text { Setuju }\end{array}$ \\
\hline 2 & Integritas Kerja Terkait Peng & lolaan S & & & \\
\hline & $\begin{array}{l}\text { a. Dalam instansi saya, } \\
\text { proses penerimaan } \\
\text { pegawai telah bersih } \\
\text { dari KKN }\end{array}$ & 31.0 & 41.4 & 13.8 & 3.4 \\
\hline & $\begin{array}{l}\text { b. Dalam instansi saya, } \\
\text { proses penempatan/ } \\
\text { redistribusi pegawai } \\
\text { telah bersih dari KKN }\end{array}$ & 20.7 & 37.9 & 20.7 & 3.4 \\
\hline & $\begin{array}{lr}\text { c. Dalam instansi saya, } \\
\text { proses } \\
\text { kenaikan jabatan telah } \\
\text { berjalan bersih dari KKN }\end{array}$ & 34.5 & 24.1 & 20.7 & 6.9 \\
\hline & $\begin{array}{l}\text { d. Dalam instansi saya, } \\
\text { proses pemilihan/ } \\
\text { persetujuan pegawai } \\
\text { yang akan ikut dalam } \\
\text { program pengembangan } \\
\text { kompetensi (diklat/ } \\
\text { beasiswa dll) telah } \\
\text { bersih dari KKN }\end{array}$ & 27.6 & 41.4 & 17.2 & 0.0 \\
\hline
\end{tabular}




\begin{tabular}{|c|c|c|c|c|c|}
\hline \multirow[b]{2}{*}{ NO } & \multirow[b]{2}{*}{ RINCIAN PERTANYAAN } & \multicolumn{4}{|c|}{ KUALITAS INTEGRITAS (\%) } \\
\hline & & $\begin{array}{l}\text { Sangat } \\
\text { Setuju }\end{array}$ & Setuju & $\begin{array}{l}\text { Tidak } \\
\text { Setuju }\end{array}$ & $\begin{array}{l}\text { Sangat } \\
\text { Tidak } \\
\text { Setuju }\end{array}$ \\
\hline & $\begin{array}{l}\text { e. Dalam instansi saya, } \\
\text { proses pengurusan } \\
\text { kenaikan pangkat telah } \\
\text { bebas dari KKN }\end{array}$ & 27.6 & 48.3 & 6.9 & 3.4 \\
\hline & $\begin{array}{l}\text { f. Dalam instansi saya, } \\
\text { proses pengurusan gaji } \\
\text { berkala telah bebas dari } \\
\text { KKN }\end{array}$ & 34.5 & 48.3 & 0.0 & 0.0 \\
\hline & $\begin{array}{l}\text { g. Dalam instansi saya, } \\
\text { proses pengalolaan } \\
\text { absensi pegawai telah } \\
\text { bebas dari manipulasi }\end{array}$ & 24.1 & 41.4 & 13.8 & 0.0 \\
\hline 3 & \multicolumn{5}{|c|}{ Integritas Kerja dan Pelaksanaan Anggaran } \\
\hline & $\begin{array}{l}\text { a. Dalam instansi saya, } \\
\text { pengelolaan anggaran } \\
\text { pada pengeluaran } \\
\text { perjalanan dinas dan } \\
\text { biaya operasional telah } \\
\text { bebas dari } \\
\text { penyalahgunaan/penyi } \\
\text { mpangan }\end{array}$ & 31.0 & 44.8 & 20.7 & 3.4 \\
\hline
\end{tabular}




\begin{tabular}{|c|c|c|c|c|c|}
\hline \multirow[b]{2}{*}{ NO } & \multirow[b]{2}{*}{ RINCIAN PERTANYAAN } & \multicolumn{4}{|c|}{ KUALITAS INTEGRITAS (\%) } \\
\hline & & $\begin{array}{l}\text { Sangat } \\
\text { Setuju }\end{array}$ & Setuju & $\begin{array}{l}\text { Tidak } \\
\text { Setuju }\end{array}$ & $\begin{array}{l}\text { Sangat } \\
\text { Tidak } \\
\text { Setuju }\end{array}$ \\
\hline & $\begin{array}{l}\text { b. Dalam instansi saya, } \\
\text { pengelolaan anggaran } \\
\text { pengadaan barang dan } \\
\text { jasa (PBJ) telah bebas } \\
\text { dari penyalahgunaan/ } \\
\text { penyimpangan }\end{array}$ & 20.7 & 58.6 & 17.2 & 0.0 \\
\hline & $\begin{array}{l}\text { c. Dalam instansi saya, } \\
\text { pengelolaan anggaran } \\
\text { biaya penunjang } \\
\text { pelaksanaan kegiatan } \\
\text { (honorarium/lembur) } \\
\text { telah bebas dari } \\
\text { penyalahgunaan/ } \\
\text { penyimpangan }\end{array}$ & 17.2 & 48.3 & 24.1 & 0.0 \\
\hline & $\begin{array}{l}\text { d. Dalam instansi saya } \\
\text { telah terbebas dari } \\
\text { praktik pemalsuan bukti } \\
\text { transaksi }\end{array}$ & 34.5 & 44.8 & 17.2 & 3.4 \\
\hline 4 & \multicolumn{5}{|c|}{$\begin{array}{l}\text { Integritas Kerja dan Kesesuaian Perintah Atasan dengan Aturan } \\
\text { dan Norma }\end{array}$} \\
\hline & $\begin{array}{l}\text { a. Atasan di instansi saya } \\
\text { bertanggungjawab atas }\end{array}$ & 17.2 & 58.6 & 20.7 & 0.0 \\
\hline
\end{tabular}




\begin{tabular}{|c|c|c|c|c|c|}
\hline \multirow[b]{2}{*}{ NO } & \multirow[b]{2}{*}{ RINCIAN PERTANYAAN } & \multicolumn{4}{|c|}{ KUALITAS INTEGRITAS (\%) } \\
\hline & & $\begin{array}{l}\text { Sangat } \\
\text { Setuju }\end{array}$ & Setuju & $\begin{array}{l}\text { Tidak } \\
\text { Setuju }\end{array}$ & $\begin{array}{l}\text { Sangat } \\
\text { Tidak } \\
\text { Setuju }\end{array}$ \\
\hline & $\begin{array}{l}\text { pekerjaan sesuai tugas } \\
\text { dan fungsi yang } \\
\text { ditetapkan }\end{array}$ & & & & \\
\hline & $\begin{array}{l}\text { b. Atasan di instansi saya } \\
\text { selalu menaati dan } \\
\text { memberikan perintah } \\
\text { kerja sesuai aturan }\end{array}$ & 17.2 & 37.9 & 20.7 & 0.0 \\
\hline & $\begin{array}{l}\text { c. Atasan di instansi saya } \\
\text { memberikan perlakuan } \\
\text { tidak } \\
\text { menyenangkan/merugi } \\
\text { kan saat saya } \\
\text { melakukan pekerjaan } \\
\text { /tugas yang tidak sesuai } \\
\text { dengan aturan tersebut }\end{array}$ & 20.7 & 37.9 & 31.0 & 10.3 \\
\hline & $\begin{array}{l}\text { d. Atasan di instansi saya } \\
\text { selalu mematuhi kode } \\
\text { etik dan aturan disiplin } \\
\text { organisasi }\end{array}$ & 20.7 & 48.3 & 20.7 & 0.0 \\
\hline
\end{tabular}




\section{Analisis}

Data hasil isian kuesioner yang telah diisi kemudian dianalisis. Ada empat dimensi yang dianalisis sesuai dengan instrument yang diberikan ke responden yaitu:

Budaya organisasi dan sistem antikorupsi

1. $3 \%$ pegawai melihat/mendengar ada beberapa tugas/pekerjaan yang belum transparan dan tidak dapat diakses oleh semua pihak yang membutuhkan keberadaan perantara di instansi (unit kerja);

2. $3 \%$ pegawai melihat masih ada praktik nepotisme dalam pelaksanaan tugas di instansinya;

3. $6 \%$ pegawai melihat masih ada praktik suap di instansinya;

4. $6 \%$ pegawai melihat pelapor terkait korupsi dan pelanggaran belum dilindungi secara efektif;

5. $3 \%$ pegawai masih melihat/mendengar belum adanya proses hukum yang tegas/adil terhadap pelaku pelanggaran;

6. $14 \%$ pegawai melihat/mendengar sistem pencegahan korupsi di internal belum berjalan efektif;

7. Hasil ini mengindikasikan bahwa secara umum hasil penelitian menunjukkan bahwa persepsi pengguna terkait transparansi cukup baik meski demikian masih terdapat isu ketidakadilan layanan ketika memproses perizinan atau memberi layanan yang perlu diperhatikan, penegakan pelanggaran korupsi di Kementerian Agama masih menjadi isu yang harus dibenahi. 


\section{Pengelolaan SDM}

1. $17 \%$ pegawai melihat/mendengar bahwa proses penerimaan pegawai masih diwarnai KKN;

2. $24 \%$ pegawai melihat/mendengar bahwa proses penempatan pegawai masih diwarnai KKN;

3. $28 \%$ pegawai melihat/mendengar bahwa proses promosi masih diwarnai KKN;

4. $17 \%$ pegawai melihat/mendengar bahwa proses pengembangan kompetensi masih diwarnai KKN;

5. $10 \%$ pegawai melihat/mendengar bahwa proses pengurusan kenaikan pangkat masih diwarnai KKN;

6. $14 \%$ pegawai melihat/mendengar bahwa proses pengelolaan absensi masih diwarnai KKN;

7. Hasil ini menunjukkan KKN dalam pengelolaan SDM masih menjadi tantangan dalam menciptakan birokrasi yang bersih di Indonesia.

Pengelolaan Anggaran

1. $24 \%$ pegawai percaya bahwa terjadi penyalahgunaan/penyimpangan pengelolaan anggaran pada pengeluaran perjalanan dinas dan biaya operasional;

2. $17 \%$ pegawai percaya bahwa terjadi penyalahgunaan/penyimpangan pengelolaan anggaran pengadaan barang dan jasa;

3. $24 \%$ pegawai percaya bahwa terjadi penyalahgunaan/penyimpangan pengelolaan anggaran biaya penunjang pelaksanaan kegiatan (honorarium/lembur) telah bebas anggaran di instansinya; 
4. $20 \%$ pegawai percaya bahwa terjadi penyalahgunaan/penyimpangan pemalsuan bukti transaksi;

5. Hasil ini mengindikasikan kebutuhan untuk mendorong pengelolaan anggaran yang lebih transparan dan anggaran sebagai salah satu fokus utama pencegahan korupsi.

Integritas kerja dan kesesuaian perintah atasan dengan aturan dan norma

1. $21 \%$ pegawai melihat/mendengar masih ada atasan yang bekerja tidak sesuai tugas fungsi yang ditetapkan;

2. $21 \%$ pegawai melihat/mendengar masih ada atasan yang memberikan tugas tidak sesuai aturan;

3. $41 \%$ pegawai melihat/mendengar masih ada atasan di instansinya memberikan perlakuan tidak menyenangkan/merugikan;

4. $21 \%$ pegawai melihat/mendengar masih ada atasan belum mematuhi kode etik dan aturan disiplin organisasi;

5. Hasil ini menunjukkan masih rendahnya kesadaran atasan untuk melaksanakan tugas sesuai tugas dan fungsinya serta aturan.

\section{Penutup}

\section{Simpulan}

Hasil analisis penelitian integritas ini menyimpulkan masih terjadi sejumlah permasalahan pada sejumlah aspek namun skalanya tidak terlalu besar. Permasalahan pada aspek transparansi, sistem antikorupsi dan integritas pegawai, pemberian perlakuan khusus yang tidak sesuai aturan berdasarkan kedekatan, suku, atau almamater, ketidakpercayaan pada 
tindaklanjut pada pelaku atau pelapor korupsi, belum tercapainya pegawai yang menjunjung tinggi kejujuran dan kebebasan dari kepentingan pribadi. Sejak beberapa tahun belakangan ini, baik masyarakat sebagai pengguna layanan ataupun pegawai masih melihat atau mendengar terjadinya pelanggaran terkait korupsi.

\section{Rekomendasi}

Berdasarkan permasalahan yang terjadi, penelitian ini memberikan rekomendasi kepada pembuat kepentingan Kementerian Agama untuk melakukan Penguatan Sistem Antikorupsi melalui:

1. Peningkatan efektivitas sosialisasi antikorupsi baik oleh internal maupun dari lembaga-lembaga yang bergerak di pencegahan korupsi secara rutin. Sosialisasi berkala untuk meningkatkan kesadaran pegawai dan pengguna layanan menjadi suatu keharusan bagi instansi untuk berbenah;

2. Penegakan hukum dan konsistensinya;

3. Penguatan whistleblowing system untuk meningkatkan partisipasi pelapor;

4. Perlidungan terhadap pelapor;

5. Pengelolaan benturan kepentingan dan penguatan kode etik dengan cara memperkuat aturan dan implementasi pengelolaan konflik kepentingan dan kode etik di Kementerian Agama. Pendekatan ini dilakukan untuk mendorong berperilaku tidak saja sesuai dengan peraturan yang berlaku tetapi lebih dari itu, yaitu bertindak berdasarkan standar etika yang telah ditetapkan oleh institusi. Cakupan yang diatur tidak saja pada saat pemberian layanan tetapi 
mencakup proses internal seperti promosi dan mutasi dan proses internal lainnya seperti pengadaan barang dan jasa;

6. Mengurangi peran perantara. Inisiatif untuk mengurangi peran perantara dalam layanan dapat menggunakan teknologi dalam bentuk layanan online, akses informasi, deregulasi aturan dan pemangkasan birokrasi yang menghambat dan tidak diperlukan dalam layanan;

7. Peningkatan kesadaran risiko korupsi di tingkat organisasi dengan cara pelatihan untuk tingkatan Pimpinan (struktural) dan Inspektorat (Pengawasan Internal) untuk mengidentifikasi dan mengatasi korupsi hingga menghindari penyalahgunaan wewenang;

8. Optimalisasi peran atasan dikombinasikan dengan pengawasan internal dan eksternal mampu menekan frekuensi kejadian korupsi dan penyalahgunaan wewenang yang muncul;

9. Mendorong penelitian integritas dilakukan secara berkala. 


\section{BAGIAN V}

\section{LIVING IN HARMONY BY IMPLEMENTING MODERATION IN RELIGIOUS LIFE}

\section{A. Introduction}

The Minister of Religious Affairs, Fachrul Razi, when giving direction on religious moderation before the UIN North Sumatra academic community (5 January 2020), underlined that the Ministry of Religious Affairs continued to intensify this movement (Wandi, infopublik: 2020). However, Fachrul Razi stressed that what is moderated is the way of religion, not religion. "Religion has been extraordinarily moderate. Until the end of the age, it still prevails. What is moderated is our way of religion, especially when dealing with people of different faiths," he said.

The term religious moderation which is currently hot, is a sexy problem that is always studied, discussed and even debated. According to the author's understanding, religious moderation has been taught and practiced by Muslims. The writer remembers when she was a child, how her parents taught her about respecting non-Muslim neighbors, one of them by giving food to neighbors, whether they are Muslims or not, inviting them at 
weddings, and instead we fulfilled their wedding invitations. For worship, it is clearly ordered not to interfere with each other, especially in matters of faith, clearly there are differences. But we remained close, side by side in harmony, playing together, gathering and joking. When the writer was still in elementary school, the writer remembered a non-Muslim neighbor who was carrying out circumcisions for his son, some of his Muslim neighbors were shocked and then asked if this was also taught in his religion. It turned out that this was done for the sake of health, he said. Eventually the other neighbors realized that the non-Muslims also appreciated this circumcision worship procedure because the wisdom and benefits for health. So, as long as the problems that occur are not related to the faith and worship, all Muslims in my place of residence feel safe and comfortable neighboring with non-Muslims. Our religious and social life is very peaceful and harmonious, that is what the writer feels.

Religious moderation is very closely related to the creation of an atmosphere of mutual respect and maintaining harmony between religious communities. If related to this matter, the role of the Ministry of Religious Affairs will be very urgent in the effort to realize it. Of course it is not possible for the Ministry of Religious Affairs to work alone, there must also be efforts to embrace, work hand-in-hand, and encourage cooperation from many parties, but the role of the Ministry of Religious Affairs is absolutely enormous and is the front guard.

Based on the background mentioned above, the writer states the problems of the research as follows: (1) What is moderation in religious life? (2) How is the role of the Ministry of Religious Affairs in realizing it? The purpose of this research is to find out the importance of implementing 
moderation in religious life and the efforts of The Ministry of Religious Affairs in realizing it.

\section{B. Understanding of Moderation in Religious Life}

Windy Novia (2009) states that moderation is containment of lust; softening; softness; simplification. Oman Fathurahman (Yasin, kliksaja.com: 2019) states about the notion of religious moderation as follows. Religious moderation can be understood as an attitude and behavior always taking a position in the middle (wasathiyah), always acting justly, and not being extreme in religious practice. So, every religious community member, whatever their ethnicity, culture, religion, and political choices must be willing to listen to each other, and learn to practice their ability to manage and overcome differences between them.

In Arabic, moderation is known as the word wasath or wasathiyah, which has the equivalent meaning with the words tawassuth (middle), iidal (fair), and tawazun (balanced). People who apply the principle of wasathiyah can be called wasith. In Arabic too, the word wasathiyah is interpreted as "the best choice". Whatever words are used, they all imply the same meaning, which is fair, which in this context means choosing the middle ground position among extreme choices. The word wasith has even been absorbed into Indonesian into the word 'referee' which has three meanings, namely: mediator, intermediary (for example in trade, business); 2) divorce (separator, conciliator) between the disputes; and 3) the leader in the match (Badan Litbang dan Diklat: 2019).

According to Arabic experts, the word wasath also means "everything that is good according to its object". For example, the word "benefactor", which means attitude between miser and wasteful, or the word "brave", 
which means attitude between coward (al-jubn) and desperate (tahawur), and many other examples in Arabic.

Moderation of Islam in Arabic is called al-Wasathiyyah al-Islamiyyah. Al-Qardawi mentions several vocabularies that are similar in meaning to the words including Tawazun, I'tidal, Ta'adul and Istiqamah. While in English it is referred to as Islamic Moderation. Islamic moderation is a view or attitude that always tries to take the middle position of two opposing and excessive attitudes so that one of the two attitudes meant does not dominate in one's mind and attitude. In other words, a moderate Muslim is a Muslim who gives each value or aspect opposite a certain portion not more than the proper portion.

The term moderation according to Khaled Abou el Fadl in The Great Theft (Misrawi: 2010) is a concept that takes a middle ground, namely understanding that is neither extreme right nor extreme left. The opposite of moderation is excessive, or tatharruf in Arabic, which contains extreme, radical, and excessive meanings in English. The word extreme can also mean "going out of line, going from end to end, turning around, taking actions/the opposite way". In Kamus Besar Bahasa Indonesia, the word extreme is defined as "paling ujung, paling tinggi, dan paling keras", "the very end, the highest, and the loudest".

In Arabic, there are at least two words whose meanings are the same as extreme words, namely al-guluw, and tasyaddud. Although the word tasyaddud in this term is not mentioned in the Qur'an, its derivatives can be found in other words, for example the words shadid, syidad, and asyadd. These three words are limited to the basic word, which means hard and firm, none of the three can be perceived as translations of extreme or tasyaddud. In the context of religion, this definition of "excessive" can be 
applied to refer to people who are extreme, and to exceed the limits and provisions of religious law.

If it is analogized, moderation is like motion from the edge which always tends toward the center or axis (centripetal), while extremism is the opposite movement away from the center or axis, towards the outer and extreme sides (centrifugal). Like a pendulum clock, there is dynamic motion, it does not stop at one extreme outside, but moves toward the middle. In the context of religion, moderate attitude is thus a choice to have a perspective, attitude, and behavior in the midst of the extreme choices available, while religious extremism is a way of looking, attitude, and behavior beyond the limits of moderation in religious understanding and practice. Therefore, religious moderation can then be understood as a perspective, attitude, and behavior of always taking a position in the middle, always acting justly, and not being extreme in religion. Of course there needs to be measurements, limits, and indicators to determine whether a particular perspective, attitude and religious behavior is classified as moderate or extreme. These measures can be made based on reliable sources, such as religious texts, the state constitution, local wisdom, and consensus and collective agreements.

Religious moderation must be understood as a balanced religious attitude between the practice of one's own religion (exclusive) and respect for the religious practices of others of different faiths (inclusive). Balance or middle ground in the practice of religion will undoubtedly prevent us from excessive extremism, fanaticism and revolutionary attitude in religion. As indicated earlier, religious moderation is the solution to the presence of two extreme poles in religion, an ultraconservative or extreme right pole on one side, and liberal or extreme left on the other. 
Moderation is very closely related to tolerance, because tolerance is the willingness and ability to be willing to respect and appreciate differences that exist on the other side. In religion, this willingness to accept does not in any way mean to interfere with, reduce, or eliminate the basic beliefs of the principles of our religious teachings. In fact, religion teaches that each of us is willing to respect and appreciate differences in faith or belief that exist on the other side. Belief is the right of every human being who must therefore be guarded together. We have the doctrine of 'tolerance', an inheritance that teaches us to be willing and able to share what is felt by others who are different from us. A value of local wisdom derived from religious teachings, Oman Fathurahman (2019).

\section{Implementing Moderation in Religious Life}

The principles of conflict prevention are laid out within the framework of government policies and the interests of the community. Government policy is actually the main capital in caring for and maintaining harmony and peace. With equitable, equitable, and prosperous development, the opportunities and potential for conflict will be easier to prevent than in the condition of an unprosperous society. That is why, peacebuilding (sustainability of peace) will be easily realized if the government is able to realize a just and prosperous socio-economic condition of the people. The principle is that the government has a major contribution in seeking policies that are fair and prosperous for the people.

In this context, the government conducts development planning and implementation that takes into account the aspirations of the community, applies the principles of good governance, conducts peace programs in areas of potential conflict, intensifies dialogue between community groups, 
enforces the law without discrimination, builds the character of the nation, preserves the values of Pancasila and wisdom, and holds consultations with community groups to build partnerships with businesses in the local area.

The main principle attached to the community is the development of tolerance and openness (inclusive). A tolerant and inclusive society will easily care for harmony. If there is a dispute between communities, it will be easy to deliberate with common sense, not with violence. Conversely, in a society that is suspicious and intolerant of pluralism, small disputes will easily ignite into major conflicts because they will be easily provoked into violent conflict situations.

Therefore, a tolerant and inclusive society will consciously develop an attitude of tolerance and mutual respect for freedom to practice worship in accordance with their religion and beliefs, respecting the differences in ethnicity, language, and customs of others, recognizing and treating humans according to their dignity, recognizing equality of human rights of every human being regardless of ethnicity, descent, religion, creed, sex, social position, and skin color, developing the unity of Indonesia on the basis of diversity-singularity and/or respecting the opinions and freedoms of others.

Thus, in principle conflict can be prevented from the beginning if the government develops a paradigm of development that is just and prosperous which is shown in the condition of a prosperous society. Conflicts can also be prevented in a tolerant and inclusive public awareness, so that differences and disputes that arise in the community can be resolved by deliberation. Following are some important things as an effort to show the role of the Ministry of Religious Affairs that can be done in realizing religious moderation. 


\section{Actor Mapping for Conflict Prevention}

Conflict prevention is actually a mandate carried by the government as part of the social conflict handling cycle. Law No. 7 of 2012 concerning Handling of Social Conflicts which contains three main points of conflict management, namely conflict prevention, conflict cessation, and postconflict recovery giving responsibilities to the district / city and provincial and central and provincial levels of government to carry out conflict handling. In fact, in order to guarantee the creation of conducive social, legal and domestic security conditions in supporting the smooth development of national development, the President issued Presidential Instruction No. 2/2013 concerning Tackling Domestic Security Disruptions. The Presidential Instruction can be used by the provincial and regency/city regional governments as a legal reference to control the regional conduciveness by carrying out their functions as chair of the integrated team at the regional level.

That is why, policies made by the Regional Government will be very decisive in handling religious-based conflicts. This is also regulated in a Joint Regulation of the Minister of Internal Affairs and Minister of Religious Affairs No. 8 and 9 of 2006 concerning Guidelines for Implementing Duties of Regional Heads/Deputy Regional Heads in Maintaining Religious Harmony, Empowering Religious Harmony Forums, and Establishing Houses of Worship. If local government fails to formulate the right policies in handling conflicts based on religion, the conflict will not be finished, and can even add to the long suffering of conflict victims.

However, in the context of conflict prevention, the government cannot do it alone, but needs to involve many groups that have influence in the community, including inviting the Ministry of Religious Affairs with its 
madrasa teachers and religious leaders. At the very least, there are several community groups that have an important role in conflict prevention, namely religious leaders, community leaders, traditional leaders and madrasa teachers. In fact, it is religious leaders, community leaders, and traditional leaders who are the most effective at preventing conflict because their voices are still heard by the community. So when there is a dispute, they can be the catalyst/filter so that it does not develop into a massive conflict. If they can act as catalysts/filters, then massive conflicts can be prevented, on the contrary they can also become conflict accelerators becoming more widespread. Their provocation to attack other groups is very effective in influencing the community. In this condition, conflict prevention efforts cannot be carried out by the government alone, but must involve religious leaders and teachers so that they become the vanguard as catalysts/filters for every issue that can lead to conflict.

Religious leaders who have the power to strengthen religious harmony can be classified into three groups, namely (1) religious leaders who are members of the Forum for Religious Harmony (FKUB), (2) religious leaders outside FKUB , but they have affiliation with the place of religious harmony which the formation is not facilitated by the government, and (3) religious leaders who move individually in strengthening religious harmony. It is these three groups that actually make efforts to strengthen religious harmony in the midst of society, especially in the aspect of preventing and stopping conflicts between religious believers.

Teachers also have a significant role in conflict prevention, especially in the context of inculcating moderate religious values. Teachers in schools/madrasas, especially in the field of religious studies, are the main actors in schools/madrasas in instilling moderate religious teachings. With 
a moderate religious understanding, students are expected to translate it outside of schools/madrasas.

Institutionally, the government can invite religious institutions, organizations and forums, such as Non-Government Organizations (NGOs) engaged in harmony, FKUB, and moderate Islamic organizations, such as Nahdlatul Ulama and Muhammadiyah to conduct conflict prevention. They can be involved in the agenda of socialization of harmony, dialogue of harmony, cooperation in harmony, and even formulate and implement a conflict early warning system facilitated by the government.

Conflict prevention actually relies on the preservation of harmonious and peaceful conditions in the community. If people live in harmony, even though they differ in religion, ethnicity, and class, then the community can naturally conduct conflict prevention. That is the reason, a harmonious and peaceful condition of the community is the essence of conflict prevention. Preservation of harmony actually depends on the religious understanding of the community. If a society has an extreme and radical understanding of religion, then what happens is mutual suspicion, tension, and hostility among religious communities. This religious understanding is strongly influenced by interpretations of the doctrines of religious teachings because religion provides texts that explain war and peace at the same time. Here, religious interpretation plays a role in the construction of religious understanding of society. In addition, mutual suspicion, tension, and hostility among religious communities is also influenced by social, political, and economic contexts.

Conflict can be avoided if religious people can utilize theological views with a harmonious perspective, such as tolerance, moderation, mutual respect, and the willingness to live together in a society. Development of 
such insights must be realized in concrete activities at all levels of social society.

In this context, the socialization of harmony must remain a common agenda so that the views and attitudes of the socio-religious community from the outset tend to have a harmonious and peaceful social life. If the community is constantly exposed to suspicious social and religious views and attitudes, then the conditions of peace will be easily torn apart. Socialization of harmony is the first step of conflict prevention, especially to mainstream social views and attitudes that encourage a harmonious and peaceful life.

Therefore, to prevent conflicts between religious believers, moderate and tolerant religious understanding is needed. Moderate in terms of religious understanding that is not extreme and radical. Tolerant in the sense of accepting religious differences that are embraced by the community and willing to live side by side with them peacefully. Mainstreaming moderate and tolerant religious understanding is carried out by religious leaders and teachers. Because they are the people who become public figures. Their voices are easily heard and still obeyed by the public.

Religious leaders are functional actors who can filter the development of issues that can complicate conflicts or conversely functional actors that can provoke violence. This is where religious leaders are encouraged to become functional actors who can filter out potential issues of conflict and turn into issues of harmony and peace. The main precondition of religious leaders to be peaceful functional actors is that they must first have a moderate religious understanding. With a moderate and tolerant religious 
understanding, religious leaders can reduce issues that can damage harmony and religious leaders do not easily provoke people to conflict.

The teacher also has a significant role in shaping the character of student knowledge. Even though the role of the teacher is different from that of religious leaders, but during activities in schools/madrasas, the teacher is still heard by students. It is the students who will become the next generation who will make Indonesia a peaceful country. In this position, the role of teachers in schools/madrasas cannot be ignored in forming national harmony. There are a number of moderate socialization programs on diversity that can be carried out, namely mainstreaming harmony in the media, houses of worship, and education.

\section{Education in Harmony}

Education is a learning process that emphasizes the cultivation of noble values so that education becomes a vehicle to shape the character of society. The cultivation of harmonious and peaceful living in the education area is an effective tool to give birth to a generation that encourages peace in society. With the values of harmony taught, students can form characters who love peace, mutual respect, and respect for religious life. Harmony education can be carried out in the form of religious education, religious schools/madrasas, and religious education, such as majlis taklim, diniyah, and pesantren (Islamic boarding school).

In the area of education, there are two main actors who are competent in mainstreaming harmony, namely religious leaders and teachers. Religious leaders can disseminate moderate religious understanding in several forms of religious education, such as majlis taklim, religious studies, pesantren, and diniyah. While teachers can disseminate moderate religious 
understanding in the form of religious education, namely religious schools/madrasas.

\section{Dialogue in Harmony}

The plurality that becomes a social reality in the community holds the potential for great conflict. For this reason, conflicts need to be prevented. The next step in socializing harmony is religious dialogue. Religious dialogue is a meeting between religious leaders to discuss models of harmony in society. As a way, religious dialogue is still considered necessary so that religious leaders can often meet, discuss, and exchange ideas in maintaining harmony. If they hold a dialogue of harmony, then the attitude of suspicion, hatred and even hostility, can be tempered by the frequent meetings and dialogues.

Interreligious dialogue is usually held by religious elites in limited forums. Because it is they who are seen as representing religious people. Their character is still heard and obeyed by their people. The dialogue of this figure is often seen as elitist and not populist. Whereas the religious elite and the community are a unity in maintaining religious harmony. For this reason, interreligious dialogue has begun to be encouraged not to be elitist in nature, but rather to involve people in a limited way as a dialogue in dialoguing differences.

Interfaith dialogue seeks to find a basis for shared ethical and moral values for efforts to build a good religious life in Indonesia, which is to look for a shared ethics. Dialogue will foster tolerance among religious communities as well as discuss constructively and find solutions to every conflict in society, especially conflicts that are motivated by religious issues.

The dialogue of harmony is not a dialogue about faith (aqeedah), because the issue of faith is in God's territory which does not need to be 
argued. Dialogue is held to find social solutions to problems faced by the community. They sit together not to debate the Godhead, but rather to find a way out so that the community can overcome the social problems they face.

In the past, interfaith dialogue always discussed faith (theological aspects) which indeed could not be found the meeting point. At present, interfaith dialogue is encouraged to discuss social issues, such as poverty, health, and education. Within this framework, interfaith dialogue can provide the best way to solve social problems.

\section{Collaboration in Harmony}

After religious leaders held a dialogue of harmony, they were encouraged again to carry out interfaith cooperation on humanitarian issues, such as poverty alleviation, eradication of corruption, equitable education, and so forth. This collaboration is carried out to concretize what has been discussed in the Harmony Dialogue. Harmony collaboration not only involves religious leaders from different religions, but also involves other groups who support harmony cooperation.

The intended cooperation is not at the level of religious rituals such as joint worship, but cooperation in the fields of education, health, disaster management, and the economy. Strengthening religious harmony can be formed from ongoing collaboration so as to reduce suspicion and jealousy among followers of religion. If it has worked together, suspicion and jealousy can be eliminated naturally without the need for indoctrination or ideologization.

Religious leaders who carry out social cooperation will become role models for their followers so that a peaceful and harmonious atmosphere will develop because social integration has been encouraged by 
cooperation, not unfair competition. Living together among religious communities naturally in social cooperation is an effective medium to prevent conflict. Because renewal is an effective model for avoiding social segregation, which is vulnerable to conflict. This is where life blends with different religious groups will affect the level of tolerance. Tolerance arises because what the community faces is difference. Like it or not, each individual must share and be tolerant of every difference. That is why, this mingling life must be based on the same spirit, which is respecting religious differences. In turn, with this collaboration it will be easy to maintain and preserve religious harmony. In many ways, collaboration between different religious leaders can foster religious harmony.

\section{Conclusion}

The role of the Ministry of Religious Affairs in maintaining harmony is very important, but it is necessary to strengthen and improve coordination in maintaining harmony, namely cross-sectoral coordination. This coordination was carried out to design harmony maintenance in each region, which differed in the level of interreligious relations.

The Ministry of Religious Affairs needs to improve cross-sectoral coordination in maintaining harmony. There are several levels of coordination that need to be undertaken by the Ministry of Religious Affairs. First, coordination with the Ministry of Internal Affairs, especially the Regional Government (City/ Regency and Provincial Government). In accordance with the 2006 PBM mandate, the Regional Head has the duty to maintain inter-religious harmony. For this reason, the Ministry of Religious Affairs and the Regional Government need to intensively coordinate efforts to maintain harmony in the community. With strong coordination from the 
beginning, especially in developing a harmony program, socialization, dialogue and collaboration can continue to be fostered.

Second, coordination with the Ministry of Education and Culture. At this level, Islamic religious teachers (PAI) who teach in schools have a strategic role in educating harmony to students. In addition, textbooks and enrichment books can also be oriented to the principles of harmony, so that early on, interreligious hostility can be prevented at school. At this level, because education affairs have been economized, the Ministry of Religious Affairs also coordinates with the Regional Government.

Third, coordination with FKUB. FKUB is a place for religious people whose formation is facilitated by the Regional Government and the Ministry of Religious Affairs (Ridwan Lubis: 2011). The purpose of forming FKUB is to maintain and develop religious harmony in the life of society, nation and state. FKUB is not a structural part of the government. FKUB remains a cultural forum for religious leaders in maintaining inter-religious harmony. With this conception, the regional government and the Ministry of Religious Affairs in the regions have the responsibility to empower FKUB in the form of operational funds, buildings, and programs, although the amount of the budget in each region varies.

Fourth, invite religious leaders to spread moderate religious understanding on television and radio because it can be reached by the wider community. Religious leaders can also conduct socialization in the form of religious messages on social networks (social media), such as Facebook, Twitter, and websites. However, more serious and thorough content cannot be ignored by religious leaders in spreading moderate religious understanding. If electronic media such as television and radio rely on the affordability of the wider community, magazines and bulletins 
rely on the accuracy and equality of religious understanding content. This is where religious leaders disseminate moderate religious understanding to strengthen religious harmony.

Fifth, mainstreaming harmony in the house of worship. Religious da'wah conducted in mosques, churches, wiharas, puras and klentengs is an effective tool for strengthening religious values. The significance of the socialization of harmony through religious propaganda in places of worship is that religious leaders can spread messages of peace and harmony in each of their da'wah so that people are formed in a religious view that loves peace. 


\section{BAGIAN VI}

\section{MANAJEMEN DIRI DAN PENINGKATAN KINERJA APARATUR SIPIL NEGARA KEMENTERIAN AGAMA}

\section{A. Pendahuluan}

\section{Latar Belakang}

Aparatur Sipil Negara (ASN) merupakan subsistem terpenting dalam Pemerintahan suatu negara. ASN yang terdiri dari dua subpegawai, yaitu PNS (Pegawai Negeri Sipil) dan PPPK (Pegawai Negeri Pemerintah dengan Perjanjian Kerja) menduduki peran strategis dan determinatif dalam penyelenggaraan/pelaksanaan kegiatan atau program Pemerintah. Baik buruknya kualitas ASN menentukan berhasil tidaknya program Pemerintah atau program pembangunan.

Dewasa ini sorotan publik semakin tertuju kepada Pegawai Negri Sipil, masyarakat semakin berani dan semakin kritis menuntut hak-haknya kepada pemerintah. Peningkatan tuntutan masyarakat terhadap kinerja pemerintah tersebut, dapat dilihat dari banyaknya pengaduan. Ini merupakan indikasi masih rendahnya kualitas pelayanan yang diberikan 
aparatur pemerintah dalam hal ini Pegawai Negeri Sipil. Kecenderungan tersebut, semakin menguat pada era reformasi sekarang ini. Hal ini juga dipicu oleh perkembangan dan dominasi teknologi informasi yang mewujud pada perluasan jangkauan media massa khususnya elektronik. Oleh karena itu reformasi pelayanan publik sebagai suatu kegiatan perbaikan pelayanan yang berorientasi pada kepuasan total pelanggan, merupakan langkah yang harus diwujudkan.

Pegawai Negeri Sipil adalah bagian dari aparatur pemerintahan sebagai salah satu komponen sumber daya manusia yang mempunyai kedudukan dan peranan penting dalam organisasi pemerintahan. Pegawai Negeri Sipil merupakan tulang punggung pemerintahan dalam pelaksanaan pembangunan untuk mencapai tujuan nasional.

Dalam rangka mencapai tujuan nasional tersebut dan sebagai amanat reformasi yang salah satunya antara lain terselenggaranya good governance, diperlukan sumber daya Pegawai Negeri Sipil yang profesional dan bertanggung jawab sehingga dalam penyelenggaraan pemerintahan dan pembangunan dapat berlangsung secara berdaya guna, bersih dan akuntabel serta bebas dari korupsi, kolusi dan nepotisme. Mengingat pentingnya peran aparatur negara maka Pegawai Negeri Sipil perlu mempunyai cara kerja yang baik sehingga akan mendorong kelancaran pelayanan masyarakat baik secara individu maupun secara menyeluruh demi tercapainya tujuan organisasi pemerintahan

Lebih lanjut menurut Budiyanto (2006) pada era keterbukaan saat ini profil Pegawai negeri sipil diharapkan lebih kreatif, disiplin, berdedikasi, dan loyal, karena hal tersebut menyangkut perubahan yang bukan hanya bersifat mekanistik hubungan-hubungan antar bangsa tetapi lebih 
mendasar lagi yaitu proses universalisasi nilai-nilai yang diharapkan rakyat.

Untuk mencapai kesuksesan kinerja di Kementerian Agama, menurut Simbolon (2009) diperlukan pengamalan dalam bentuk perilaku kerja dari motto Kementerian Agama yaitu ikhlas beramal yang berarti bahwa aparatur Kementerian Agama siap memberikan pelayanan kepada pihakpihak terkait dan melaksanakan tugas secara sesuai dengan kewajibannya secara optimal, memperoleh haknya sesuai peraturan perundangan dalam memberikan pelayanan dan melaksanakan tugasnya dan tidak menuntut sesuatu di luar hak yang diterima, serta meniscayakan pelayanan yang profesional.

Menurut Brown (2005) pegawai akan bekerja lebih efektif bila memiliki manajemen diri yang baik. Disadari atau tidak, kemampuan manajemen diri berpengaruh terhadap kemampuan seseorang dalam bekerja. Seorang pegawai yang dapat mengatur dirinya dengan baik tidak akan ceroboh dalam bertindak.

Dewasa ini semakin banyak pegawai yang terjebak dalam proses pengaturan dirinya sendiri. Mereka merasa kesulitan untuk membagi waktu yang digunakan untuk mengerjakan pekerjaan kantor yang rasanya semakin menumpuk. Bila dicermati, seorang pegawai yang dapat mengatur dirinya dengan baik tidak akan kehilangan arah ke mana ia akan melangkah.

Pegawai yang mampu mengatur tingkah lakunya sendiri dan memiliki target yang jelas akan mampu membuat pertimbangan dan kemudian mengambil keputusan yang tepat baik bagi dirinya maupun unit kerja dimana ia bekerja. Orang yang memiliki kemampuan pemantauan dan evaluasi diri yang baik, tentu akan dapat memilih dan memutuskan yang terbaik bagi dirinya dan tidak merugikan orang di sekitarnya, sehingga 
pekerjaan yang dikerjakan dapat berlangsung efektif dan dapat dipertanggungjawabkan secara profesional.

Pengembangan kinerja pegawai perlu dirancang sesuai dengan visi dan misi organisasi. Di samping itu partisipasi individu secara aktif dan mandiri menjadi dinamika utamanya, sehingga kekompakan kerja dalam unit, atau kelompok kecil, secara intra maupun inter grup tercapai. Hal ini diungkapkan oleh Hadipranata, F. A., (1995). Jika pegawai berpartisipasi secara penuh dalam bekerja berarti pegawai memperhatikan kepentingankepentingan organisasi dalam mencapai tujuan-tujuannya. Pegawai menjadi lebih peduli terhadap fungsi organisasi yang efektif, sehingga lebih loyal dan berdedikasi dalam melakukan pekerjaan, serta berusaha memelihara perilaku-perilaku yang dimilikinya dalam melakukan tugas pekerjaan tersebut. Pegawai tersebut akan lebih berkomitmen dalam bekerja, karena mereka memandang usaha dan kinerja yang mereka berikan terhadap organisasi memiliki makna yang positif bagi kesejahteraan organisasi dan kesejahteraan individu mereka sendiri.

\section{Perumusan Masalah}

Berdasarkan latar belakang masalah yang telah diuraikan tersebut di atas, maka permasalahan yang terkait dengan kinerja pegawai dapat diidentifikasi sebagai berikut: "Upaya apa yang dapat dilakukan untuk meningkatkan manajemen diri pegawai sehingga akan meningkatkan pula kinerja dalam pelaksanaan tugasnya." 


\section{Manfaat}

Manfaat yang diharapkan dari kajian ini adalah sebagai berikut:

1. Hasil tulisan ini diharapkan dapat menambah kajian mengenai manajemen diri dan kinerja pegawai negeri sipil khususnya di Kementerian Agama.

2. Sebagai bahan masukan bagi Kementerian Agama dalam rangka peningkatan kinerja pegawai.

3. Hasil tulisan ini diharapkan dapat memberikan sumbangan pemikiran bagi untuk mendukung program peningkatan kinerja pegawai.

\section{B. Pembahasan}

\section{Manajemen Diri dan Peningkatan Kinerja}

Manajemen diri saat ini merupakan istilah yang sangat populer, hingga banyak seminar, pelatihan, maupun tulisan yang mengupas topik ini karena memang diperlukan bagi mereka yang berada di lingkungan professional, sosial kemasyarakatan maupun dalam kehidupan birokrasi. Manajemen diri merupakan pengendalian diri terhadap pikiran, ucapan, dan perbuatan yang kita lakukan, sehingga membantu diri menghindari hal-hal yang tidak baik dan peningkatan perbuatan yang baik dan benar.

Soekadji (1993) mengemukakan manajemen diri adalah suatu prosedur yang menuntut seseorang untuk mengarahkan atau menata tingkah lakunya sendiri. Prosedur ini melibatkan subjek dalam beberapa tahap, yaitu: 
a. Menentukan sasaran tingkah laku yang hendak dicapai

b. Memonitor tingkah laku dengan cara menentukan sendiri prosedur yang hendak dipakai untuk memonitor perkembangan yang sudah dicapai

c. Mengevaluasi perkembangan tingkah laku.

Myers (1991) mengemukakan bahwa kesempatan untuk melakukan manajemen diri dalam pekerjaan merupakan suatu bentuk tanggung jawab. Manajemen diri merupakan suatu prosedur yang mengharuskan orang menentukan target kerja yang hendak dicapainya, memonitor dan mengevaluasinya.

Manz \& Sims (1995) menguraikan bahwa manajemen diri adalah suatu metode yang digunakan oleh seseorang dalam bekerja dengan cara melakukan pengontrolan terhadap hasil kerja yang dilakukan oleh dirinya sendiri tanpa harus ada kontrol dari luar. Dengan menggunakan catatan tentang hasil kerja yang sudah lalu, mereka menilai dan mengevaluasi hasil kerja yang baru dicapainya.

Manajemen diri, menurut Gie (1996) adalah segenap kegiatan dan langkah mengatur dan mengelola diri sendiri sebaik-baiknya, sehingga mampu membawa ke arah tercapainya tujuan hidup yang telah ditetapkan oleh individu yang bersangkutan. Strategi yang pertama dan utama dalam manajemen diri adalah berusaha mengetahui diri sendiri dengan segala kekurangan dan kelebihan yang dimiliki dengan segenap kekuatan dan potensinya.

Sedangkan tentang pengertian kinerja, dalam kamus bahasa Indonesia (Daryanto, 2005) kinerja berarti sesuatu yang dicapai, prestasi diperlihatkan, kemampuan kerja. Seseorang yang dapat melaksanakan 
tugasnya dengan baik dan mencapai hasil yang memuaskan akan dapat mewujudkan tujuan organisasi atau kelompok dalam suatu unit kerja. Jadi, kinerja pegawai merupakan hasil kerja dimana para pegawai mencapai persyaratan-persyaratan pekerjaan (Simamora,1995).

Menurut Wagner dan Hollenbeck (1995) "performance is a function of the effort to understand the tasks and capabilities and its potential use as appropriate in order to achieve certain goals." Kinerja merupakan fungsi dari usaha untuk memahami tugas dan menggunakan kemampuan dan potensinya secara tepat dalam rangka mencapai tujuan tertentu. Sedangkan Baird (1996) menyatakan "performance of a development process task execution at regular intervals", mengatakan bahwa kinerja merupakan proses perkembangan pelaksanaan tugas pada rentang waktu tertentu.

Pengertian ini lebih menekankan pada proses karena kinerja merupakan suatu tindakan (action) yang melibatkan berbagai komponen dan bukan suatu peristiwa (event). Dengan demikian, kinerja tidak dapat dilihat atau diukur hanya berdasarkan hasil yang dicapai, tetapi harus dilihat atau diukur berdasarkan seluruh proses karena waktu dan sumber daya yang digunakan harus diperhitungkan.

Lebih lanjut Manz \& Sims (1995) mengatakan bahwa dengan manajemen diri maka seseorang dalam bekerja akan dapat mengontrol hasil kerjanya sendiri tanpa harus ada kontrol dari luar. Adapun strategi manajemen diri dalam meningkatkan kinerja dapat dilakukan dengan cara berusaha mengetahui diri sendiri dengan segala kekurangan dan kelebihan yang dimiliki dengan segenap kekuatan dan potensinya.

Selain itu Covey (2005) berpendapat bahwa manajemen diri tidak dapat dilepaskan dengan manajemen waktu, hal ini disebabkan karena waktu merupakan aset yang sangat berharga. Pengelolaan waktu yang tepat 
dapat menjauhkan individu dari konflik internal seperti stres, maupun konflik eksternal seperti konflik peran. Menurut Macan (1994) teknik manajemen waktu adalah cara yang digunakan dalam mengelola waktu, seperti membuat daftar, membuat skala prioritas, membuat jadwal dan rencana kegiatan sehari-hari baik di kantor maupun di rumah, misalnya pegawai membuat jadwal kegiatan yang akan dilakukan selama satu hari, apa yang harus dilakukan di rumah dan di kantor.

Berdasarkan hal di atas maka manajemen diri sangat berkaitan dengan penentuan prioritas dan tujuan, manajemen waktu, dan ketrampilan mengorganisasi. Pengelolaan diri dan waktu yang tepat dapat menghindar kan pegawai dari konflik internal dan eksternal, serta dapat menentukan prioritas dan tujuan yang telah ditetapkan atau dicita-citakan.

\section{Upaya/Strategi yang Dapat Dilakukan}

Ada beberapa macam strategi untuk melakukan manajemen diri, seperti dikemukakan oleh Gie (1996). Langkahnya antara lain:

a. Memotivasi diri

Sering dikenal dengan self motivation yaitu dorongan psikologis yang merangsang seseorang untuk melakukan berbagai kegiatan dalam rangka mencapai tujuan yang didambakan, misalnya pegawai memotivasi dirinya agar dapat melaksanakan kegiatan di kantor dengan baik tanpa mengganggu kegiatan hariannya.

b. Pengorganisasian diri

Disebut juga self organizing yaitu pengaturan yang baik terhadap pikiran, energi, waktu, tempat, benda, dan sumber daya lain dalam hidup sehingga semua dapat berjalan dengan tertib dan lancar, misalnya pegawai 
mengorganisasikan dirinya sedemikian rupa sehingga dia dapat mengambil keputusan, tanpa meninggalkan tugas dan pekerjaannya di kantor.

\section{c. Pengendalian diri}

Sering pula disebut sebagai self control yaitu berbagai tekad dan langkah untuk mendisiplinkan kemauan, memacu semangat, mengikis keseganan, dan mengerahkan energi untuk melaksanakan yang harus dilaksanakan sesuai tujuan yang didambakan, misalnya pegawai berusaha untuk melakukan semua tugas dan menyelesaikan pekerjaannya di kantor dengan baik dan tidak dibawa pulang.

Kanfer (1995) menyebutkan beberapa teknik manajemen diri, yaitu:

\section{a. Standard setting}

Menentukan sasaran, target tingkah laku atau prestasi yang hendak dicapai. Bila tujuan sudah ditetapkan, akan lebih mengarahkan seseorang pada bagaimana tujuan tersebut dapat dicapai, misalnya seorang wanita karir yang memiliki rencana dan tujuan yang mantap akan dapat mencapai kesuksesan dalam pekerjaannya.

\section{b. Self monitoring}

Bentuk aplikasi dari teknik ini antara lain dengan cara mencatat atau membuat grafik sehingga perubahan data dapat dilihat individu yang bersangkutan dan berfungsi sebagai insentif atau penguat (reinforcer), misalnya seorang pegawai memiliki sebuah catatan khusus yang digunakan untuk memantau perkembangan pekerjaannya, biasanya akan lebih cepat berkembang di bidangnya. 


\section{c. Self evaluation}

Dalam tahap ini, individu yang bersangkutan mengevaluasi kembali perkembangan rencana kerjanya, misalnya seorang pegawai mengevaluasi hasil kerjanya apakah sudah memenuhi target atau belum, karena bila belum, maka dia dapat memperbaiki diri agar targetnya dapat terpenuhi, misalnya urusan pengambilan keputusan menghambat pencapaian target pekerjaan, maka pegawai tersebut dapat berusaha menyesuaikan dan memperbaiki diri, seperti mencari cara yang menyelesaikan pekerjaan tepat pada waktunya tanpa terganggu pengambilan keputusannya.

\section{d. Self reinforcement}

Teknik menghargai diri sendiri secara positif, seperti memberi penilaian atau penghargaan terhadap apa yang telah dilakukan, misalnya seorang pegawai melakukan penilaian atas hasil kerjanya dan cara pengambilan keputusannya, bila targetnya terpenuhi, maka dia dapat menghadiahi dirinya sendiri sebagai imbalan atas usaha yang telah dilakukan.

Sementara itu Pedler \& Boydell (1995) mengemukakan bahwa tingkat efektivitas individu dalam melakukan manajemen diri dipengaruhi oleh sejauh mana individu mampu mempertahankan (surviving), memelihara (maintaining), dan mengembangkan (developing) dirinya. Empat aspek diri yang harus dimiliki oleh seorang yang memiliki manajemen diri yang baik yaitu:

\section{a. Kesehatan (health)}

Kondisi fisik maupun psikis mempengaruhi seseorang dalam mengarahkan aktivitas kehidupannya. Kesehatan fisik menjadi modal utama untuk melakukan aktivitas, kesehatan psikis menciptakan kondisi 
mental yang stabil, misalnya wanita karir yang kondisi fisik dan mentalnya baik akan dapat mengerjakan dan menyelesaikan pekerjaan dan dapat mengambil keputusan dengan baik.

b. Ketrampilan atau keahlian (skills)

Ketrampilan yang dimiliki menggambarkan kualitas individu. Individu dapat memutuskan untuk menjadi orang yang memiliki beberapa keahlian sekaligus (a multi-skilled person), misalnya seorang pegawai yang merangkap sebagai guru privat, konsultan perkawinan, juru masak, pedagang atau ahli kecantikan. Individu tersebut menjadi orang yang memiliki satu keahlian di bidang tertentu dan memberi perhatian lebih untuk meningkatkan kemampuan yang dimilikinya (a spesialist). Seorang pegawai yang memiliki keahlian khusus dalam bidang perdagangan, maka dia dapat memanfaatkan dan meningkatkan keahliannya tersebut di waktu senggangnya di rumah dengan menjalankan bisnisnya.

\section{c. Aktivitas (action)}

Seberapa jauh individu mampu menyelesaikan aktivitas hidupnya dengan baik, contohnya mampu membuat keputusan dan mengambil inisiatif, misalnya pegawai mampu mengambil keputusan dengan cepat dan memiliki ide-ide cemerlang berkaitan dengan pekerjaan dan mampu mengambil keputusan dengan tepat

\section{d. Identitas diri (identity)}

Seberapa jauh pengetahuan, pemahaman, dan penilaian individu terhadap dirinya akan mempengaruhi cara dia bertindak, misalnya pegawai yang tahu kelebihan dan kekurangan dirinya dengan baik akan dapat menentukan target pekerjaan yang akan dicapainya, tanpa harus 
memaksakan diri karena menginginkan hasil yang lebih baik, karena dia dapat menerapkan manajemen diri yang baik.

Sementara itu untuk meningkatkan kinerja, setiap Pegawai ASN memiliki hak dan kesempatan untuk mengembangkan kompetensi antara lain melalui: pendidikan dan pelatihan, seminar, kursus, dan penataran. Pengembangan kompetensi ini harus dievaluasi oleh Pejabat yang berwenang dan digunakan sebagai salah satu dasar dalam pengangkatan jabatan dan pengembangan karier. Selain itu pengembangan kompetensi ini wajib disusun dalam rencana pengembangan kompetensi tahunan dalam rencana kerja anggaran tahunan instansi.

Motivasi berprestasi pegawai untuk meningkatkan kinerja juga harus dilakukan. Di dalam UU ASN dijelaskan tentang Hak dan Kesempatan bagi ASN baik PNS maupun PPPK mengikuti pengembangan kompetensi, yaitu:

a. Memiliki hak dan kesempatan yang sama untuk diikutsertakan dalam pengembangan kompetensi, dengan memperhatikan hasil penilaian kinerja dan penilaian kompetensi yang bersangkutan.

b. Pengembangan kompetensi sebagaimana dimaksud dilakukan paling kurang 20 jam pelajaran dalam 1 (satu) tahun (Peraturan Pemerintah Nomor 11 Tahun 2017 Pasal 203 Ayat 4).

Jenis pengembangan dapat dilaksanakan melalui:

a. Pendidikan Formal

1) Pengembangan kompetensi dalam bentuk pendidikan dilakukan untuk meningkatkan pengetahuan dan keahlian PNS melalui pendidikan formal sesuai dengan peraturan perundang-undangan. 
2) Pengembangan kompetensi dalam bentuk pendidikan formal sebagaimana dimaksud diatas dilaksanakan dengan pemberian tugas belajar.

3) Pemberian tugas belajar sebagaimana dimaksud diberikan dalam rangka memenuhi kebutuhan standar kompetensi jabatan dan pengembangan karir.

b. Pelatihan

1) Pengembangan kompetensi dalam bentuk pelatihan dilakukan melalui jalur pelatihan klasikal dan non-klasikal.

2) Pengembangan kompetensi dalam bentuk pelatihan klasikal sebagaimana dimaksud, dilakukan melalui proses pembelajaran tatap muka di dalam kelas, melalui pelatihan, seminar, kursus, penataran, sosialisasi, workshop, semiloka, sekolah kader serta bentuk lain yang sejenis.

3) Pengembangan kompetensi dalam bentuk pelatihan non-klasikal sebagaimana dimaksud dilakukan melalui e-learning, bimbingan di tempat kerja, pelatihan jarak jauh, magang dan pertukaran antara PNS dan pegawai swasta serta bentuk lain yang sejenis.

\section{Penutup}

Pegawai yang memiliki manajemen diri yang positif maka akan dapat meningkatkan kinerja lebih baik lagi. Peningkatan kinerja pegawai dapat dilakukan melalui upaya-upaya diantaranya membangun dan memiliki keyakinan akan kemampuan diri dalam bekerja, mampu mengatasi hambatan yang terjadi, dapat bertahan atas segala masalah yang dihadapi, 
mengetahui kekurangan dan potensi diri dalam bekerja, melakukan manajemen waktu, disiplin, dan berorientasi bekerja dalam kelompok.

Peningkatan kinerja pegawai dapat dilakukan melalui peningkatan motivasi berprestasi pegawai dalam mengembangkan kompetensi. Upayaupaya yang perlu dilakukan adalah memberikan kesempatan pegawai untuk mengikuti pelatihan agar tetap terjaga motivasi kerjanya, memberi kesempatan untuk melanjutkan studi ke jenjang yang lebih tinggi, membentuk kelompok kerja (team work), dan menanamkan nilai kepada semua pihak yang terlibat untuk bekerja ikhlas. 


\section{BAGIAN VII}

\section{TANGGUNG JAWAB DAN AMANAH DALAM BEKERJA}

\section{A. Pendahuluan}

Sosok Pegawai Negeri Sipil (PNS) yang ideal adalah sebagaimana yang tertera dalam pasal 12 ayat 1 dan 2 Undang-undang Nomor 8 Tahun1974 sebagaimana telah diubah dengan Undang-undang Nomor 43 Tahun 1999 Tentang Pokok-Pokok Kepegawaian: "Manajemen PNS diarahkan untuk terselenggaranya tugas-tugas umum pemerintahan dan pembangunan dan untuk mewujudkan tugas-tugas tersebut maka dibutuhkan PNS yang profesional, jujur, adil dan bertanggung jawab melalui pembinaan karier dan prestasi kerja yang lebih dititikberatkan pada prestasi kerja." Adapun sosok PNS yang diharapkan dalam upaya perjuangan mencapai tujuan nasional adalah PNS yang memiliki kompetensi, penuh kesetiaan dan ketaatan kepada Pancasila, Undang- Undang Dasar 1945, dan Negara Kesatuan Republik Indonesia, profesional, berbudi pekerti luhur, berdaya guna, berhasil guna, sadar akan tanggung jawabnya sebagai unsur aparatur negara, abdi masyarakat dan abdi negara di dalam negara hukum yang 
demokratis. Untuk membentuknya tidaklah mudah, harus dilakukan selain dengan pembinaan PNS berkelanjutan juga melalui pembentukan budaya kerja.

Urgensi pembentukan budaya kerja ini dengan tanggap direspon oleh Menteri Agama, Lukman Hakim Saifuddin, yang mencanangkan lima nilai Budaya Kerja Kementerian Agama: Integritas, Profesionalitas, Inovasi, Tanggung Jawab dan Keteladanan. Pencanangan lima budaya kerja tersebut dilaksanakan bertepatan dengan Hari Amal Bhakti Kementerian Agama ke69 pada 3 Januari 2015. Disadari memang pembentukan budaya kerja dalam organisasi bukanlah satu perkara mudah dan tidak dapat dicapai dalam waktu yang singkat. Dalam usaha untuk membentuk budaya kerja dalam organisasi, maka orientasi haruslah bergerak di atas landasan yang betul sebagai prasyarat bagi tercapainya budaya kerja yang maksimal.

Dalam tulisan ini akan dibahas salah satu nilai tersebut yaitu tanggung jawab dan amanah dalam pelaksanaan tugas PNS. Mengapa nilai tanggung jawab diserangkaikan dengan amanah? Karena menurut pendapat penulis, ketika seseorang bertanggung jawab dalam pelaksanaan tugas itu dikarenakan ia menganggap bahwa tugas tersebut adalah amanah yang harus ia emban.

\section{- Perumusan Masalah}

Berdasarkan latar belakang di atas maka rumusan masalah pada tulisan ini adalah: Bagaimana membangun nilai tanggung jawab dan amanah dalam budaya kerja untuk meningkatkan kinerja aparatur Kementerian Agama? 


\section{- Tujuan Penulisan}

Adapun tujuan penulisan karya tulis ilmiah ini adalah mengetahui nilainilai tanggung jawab dan amanah dalam budaya kerja Kementerian Agama dan bagaimana cara membangunnya

\section{B. Pembahasan}

Pada tanggal 3 Januari 2015 telah dicanangkan lima nilai Budaya Kerja Kementerian Agama, yaitu Integritas, Profesionalitas, Inovasi, Tanggung Jawab dan Keteladanan. Kelima nilai tersebut merepresentasikan sekian banyak nilai yang harus dianut oleh setiap pegawai agar bekerja dengan baik. Berbicara tentang nilai tanggung jawab, dalam prinsip-prinsip etika profesi dijelaskan bahwa yang dimaksud dengan tanggung jawab adalah tanggung jawab terhadap pelaksanaan pekerjaan itu dan terhadap hasilnya. Selain itu juga tanggung jawab terhadap dampak dari profesi itu untuk kehidupan orang lain atau masyarakat pada umumnya. Kode etik PNS tersebut diatur dalam peraturan Pemerintah Nomor 42 Tahun 2004 yang juga bagian dari pembinaan bagi PNS yaitu jiwa korsa dan kode etik.

Bila seorang pribadi menerima tugas baik itu tugas bekerja atau memimpin, ia harus berani memikul tanggung jawab bagi setiap tingkah lakunya, sehubungan dengan tugas-tugas dan peranan yang harus dilakukan. Menerima tanggung jawab kepemimpinan mengandung resiko menerima sanksi tertentu bila ia tidak mampu mencapai hasil yang diharapkan. Kebanyakan pemimpin merasakan bahwa peranan sebagai pemimpin itu mengandung banyak tekanan dan tuntutan. Terutama penggunaan waktu, usaha dan pengetahuan yang dibutuhkan untuk 
melaksanakan tugas secara efektif. Dan tugas-tugas ini menuntut energi yang banyak sekali. Karena peranan kepemimpinan itu harus memenuhi persyaratan-persyaratan yang cukup berat, maka diharapkan agar orangorang yang diserahi jabatan itu benar-benar menghendaki peranannya dan sanggup menerima tanggung jawab. Menurut O. Jeff Harris (dalam Kartini Kartono 2006), orang-orang yang perlu dipilih sebagai kandidat atau calon pemimpin adalah mereka yang memiliki kualifikasi, salah satunya adalah memiiki kemauan untuk memikul tanggung jawab.

Tanggung jawab itu dapat dipelajari. Setiap orang dapat melatih, memupuk dan mengembangkan tanggung jawab itu dalam dirinya sehingga menjadi terbiasa, bertanggung jawab atas segala perbuatan dan dapat mempertanggungjawabkan tugas/amanah yang diberikan kepadanya. Latihan bertanggung jawab itu dapat dimulai pada diri sendiri. Misalnya menjaga kehormatan diri, menjaga nama baik, jangan sampai ternoda disebabkan karena perbuatan sendiri. Tanggung jawab itu menuntut supaya setiap orang dapat menunaikan tugas dan kewajiban yang diserahkan kepadanya dengan sebaik-baiknya.

Nilai tanggung jawab yang dimaksud adalah bekerja secara tuntas dan konsekuen. Indikasi positif yang menunjukkan bahwa seseorang bertanggung jawab adalah menyelesaikan pekerjaan dengan baik dan tepat waktu; berani mengakui kesalahan, bersedia menerima konsekuensi, dan melakukan langkah-langkah perbaikan; mengatasi masalah dengan segera; komitmen dengan tugas yang diberikan. Sedangkan indikasi negatif bahwa seseorang itu tidak bertanggung jawab adalah lalai dalam melaksanakan tugas; menunda-nunda dan/atau menghindar dalam melaksanakan tugas; selalu merasa benar dan suka menyalahkan orang lain; menolak resiko atas 
hasil pekerjaan; memilih-milih pekerjaan sesuai dengan keinginan pribadi; menyalahgunakan wewenang dan tanggung jawab.

Seorang PNS selain profesional juga dituntut untuk bekerja dengan tanggung jawab dan amanah. Merupakan suatu kesalahan jika kita berpikir bahwa uang adalah aset terbesar dalam kehidupan ini. Sebenarnya aset yang paling besar adalah amanah atau kepercayaan. Dengan dasar kepercayaan seseorang dapat membeli dan dapat memiliki apa saja. Kepercayaan merupakan suatu aset berharga yang dapat membeli dan lebih berharga daripada uang.

Secara bahasa amanah adalah sesuatu yang dipercayakan (dititipkan) kepada orang lain (Kamus Besar Bahasa Indonesia, 2007). Amanah secara etimologis (pendekatan kebahasaan/lughawi) dari bahasa Arab dalam bentuk mashdar dari (amina- amanatan) yang berarti jujur atau dapat dipercaya. Sedangkan dalam bahasa Indonesia amanah berarti pesan, perintah, keterangan atau wejangan.

Amanah menurut Ahmad Musthafa Al-Maraghi (1993) adalah sesuatu yang harus dipelihara dan dijaga agar sampai kepada yang berhak memilikinya. Sedangkan menurut Abu Hafbl amanah adalah suatu pesan, wasiat atau titipan yang harus disampaikan dan dilaksanakan dengan baik (2007). Tentunya tidak semua pesan atau amanah harus dilaksanakan, melainkan hanya amanah yang mendatangkan kebaikan dan perdamaian. Jika seseorang baik pejabat maupun pegawai tidak melaksanakan suatu amanah, orang itu berarti telah mengingkari janji. Islam mewajibkan amanah harus dilaksanakan. Jika dipercaya orang lain, kepercayaan itu harus dipertahankan dengan tidak mengkhianati dan mengabaikan amanah. Berapa banyak orang yang tidak dipercaya lagi karena ia tidak menjaga kepercayaan yang diberikan kepadanya. 
Amanah mempunyai akar kata yang sama dengan kata iman dan aman, sehingga mu'min berarti yang beriman, yang mendatangkan keamanan, juga yang memberi dan menerima amanah. Orang yang beriman disebut juga almu'min, karena orang yang beriman menerima rasa aman, iman dan amanah. Bila orang tidak menjalankan amanah berarti tidak beriman dan tidak akan memberikan rasa aman baik untuk dirinya dan sesama masyarakat lingkungan sosialnya. Dalam sebuah hadis dinyatakan "Tidak ada iman bagi orang yang tidak berlaku amanah".

\section{Penutup}

Akhir kata, siapa saja yang terkait dalam tugas yang berkenaan dengan pelayanan kepada masyarakat harus menyikapi secara positif pentingnya tanggung jawab dan amanah pelaksanaan tugas sebagai seorang PNS. Tugas dalam melayani masyarakat adalah amanah. Setiap orang dapat melatih, memupuk dan mengembangkan tanggung jawab dan amanah itu dalam dirinya sehingga menjadi terbiasa, tahu bertanggung jawab atas segala perbuatan dan dapat mempertanggungjawabkan tugas/amanah yang diberikan kepadanya. Dari sikap yang positif tersebut, kita akan mempunyai komitmen yang tinggi untuk menerapkan pelayanan dengan penuh tanggung jawab dan amanah. 


\section{BAGIAN VIII}

\section{SHORT COURSE NUEPA NEW DELHI}

\section{A. Pendahuluan}

\section{Gambaran Umum}

Peran strategis widyaiswara tergambar jelas sebagai pengembang mental-intelektual, penguat mental-spiritual dan pembentuk sosial-attitude bagi aparatur negara melalui diklat sehingga menjadi daya-dukung potensial dalam penyelengaraan kepemerintahan dan pelayanan masyarakat.

Widyaiswara dalam posisi ini dituntut meningkatkan kompetensi yang seimbang meliputi softskil, hardskill dan attitudeskill sebagai modalitas dalam interaksi edukatif, interaksi birokratik dan interaksi sosial sehingga tetap survive sebagai andragog dalam menyajikan layanan dengan mutu terbaik.

Upaya peningkatan kompetensi widyaiswara selama ini telah banyak dilakukan melalui pendekatan diklat, temu karya, seminar, bimtek dan pertemuan ilmiah lainnya. Pendekatan tersebut dinilai belum maksimal dapat memboboti kualitas widyaiswara. Untuk itulah upaya pendekatan 
short course dibutuhkan dalam rangka memaksimalkan kualitas widyaiswara menuju profesionalitas sebagaimana diharapkan.

\section{Dasar Hukum}

a. Undang-undang Nomor 8 Tahun 1974 tentang Pokok-pokok Kepegawaian yang telah diubah dengan Undang-undang Nomor 43 Thun 1999;

b. Peraturan Pemerintah Nomor 16 Tahun 1994 tentang Jabatan Fungsional Pegawai Negeri Sipil;

c. Peraturan Pemerintah Nomor 101 Tahun 2000 tentang Pendidikan dan Pelatihan Pegawai Negeri Sipil;

d. Keputusan Mentri Agama Nomor 1 Tahun 2003 tentang Pedoman Pendidikan dan Pelatihan Pegawai Negeri Sipil di Lingkungan Departemen Agama;

e. Keputusan Menteri Agama Nomor 345 Tanun 2004 tentang Organisasi dan Tata Kerja Balai Pendidikan dan Pelatihan Keagamaan;

f. Peraturan Menteri Agama Nomor 3 Tanun 2006 tentang Organisasi dan Tata Kerja Kementerian Agama (disempurnakan)

g. Peraturan MENPAN Nomor 14 Tahun 2009 tentang Jabatan Fungsional Widyaiswara dan Angka Kreditnya;

h. Peraturan Bersama Kepala Lembaga Administrasi Negara dan Kepala Badan Kepegawaian Negara Nomor 1 dan 2 Tahun 2010 tentang Petunjuk Pelaksanaan Jabatan Fungsional Widyaiswara dan Angka Kreditnya; 
i. Surat Kepala Badan Litbang dan Diklat Kementerian Agama No. Set.BD/3/KP.03/2396/2013 tanggal 03 Oktober 2013 tentang Pemanggilan Peserta Short Course.

\section{Tujuan dan Sasaran}

Kegiatan ini bertujuan meningkatkan kompetensi widyaiswara melalui metode short course yaitu strategi khusus belajar singkat diperguruan tinggi yang berbasis pengembangan dan peningkatan substantive kediklatan (teacher training) di luar negeri.

Tujuan lainnya yaitu memberikan pengalaman widyaiswara untuk menemukan keunggulan dan pengetahuan berwawasan internasional dalam rangka mengembangkan pengetahuan dan keterampilan yang dapat dipergunakan untuk memperbaiki dan meningkatkan kualitas diklat.

Sasaran short course yaitu widyaiswara yang berasal dari Pusdiklat Badan Litbang dan Diklat Kementerian Agama dan Balai Diklat Keagamaan.

\section{Peserta Short Course}

Peserta short course yaitu widyaiswara yang berasal dari Pusdiklat Badan Litbang dan Diklat Kementerian Agama dan Balai Diklat Keagamaan sejumlah 8 (delapan) orang hasil seleksi yang dilaksanakan oleh Sekretariat Badan Litbang dan Diklat Kementerian Agama, sebagai berikut:

a. Neneng Maria Kiptyah, M.Pd. NIP:197708142005012010 widyaiswara Pusdiklat Tenaga Administrasi Badan Litbang dan Diklat Kementerian Agama,

b. Najamuddin, S.Ag., $\quad$ M.Ag., $\quad$ NIP: 197203062003121004 widyaiswara BDK Medan 
c. Yusmarni, M.Pd. NIP: 196904221995032001 widyaiswara BDK Padang

d. Agustina, M.Pd., NIP: 198208182006042032 widyaiswara BDK Palembang

e. Samsul Falak, S.S., M.Pd., NIP: 197706062003121002 widyaiswara BDK Semarang

f. Drs. Ilham, M.Si NIP: 196811081998031001 widyaiswara BDK Makasar

g. Puryanto, S.S. NIP: 196705172005011004 widyaiswara BDK Manado

h. Dr. I Gusti Ketut Abdul Kahar, NIP: 196812311995031010 widyaiswara BDK Ambon

\section{Tempat Short Course dan Lama Waktu Pelaksanaan}

Tempat short course widyaiswara tahun 2013 yaitu National University of Educational Planning and Administration (NUEPA) DelhiIndia.

Lama waktu pelaksanaan 14 hari dari tanggal 15 s.d. 29 November 2013.

Peserta short course diinapkan pada Hostel (NUEPA) Delhi-India Jl. Sri Aurobindo Marg. No. 17-B New Delhi kode pos 110016 India. 


\section{B. Kegiatan Short Course}

\section{Pembelajaran}

Pembelajaran dilaksanakan berdasarkan tentative time table yang telah dirancang oleh Prof. Najma Akhtar sebagai professor yang bertanggung jawab terselenggaranya short course (NUEPA) Delhi India.

Limit waktu yang digunakan 480 menit/hari dengan durasi 3JP/materi dan rata-rata 3 pemateri/hari, dengan rincian sebagai berikut:

Sesi I $\quad$ : 09.15 s.d. 11.15.

Sesi II $\quad: 11.30$ s.d. 13.00

Sesi III $\quad: 14.00$ s.d. 17.00

Tea $\quad: 11.15$ s.d. 11.30

Lunch $\quad: 13.00$ s.d. 14.00

Pembelajaran dimulai dari 09.15 s.d. 17.00 waktu New Delhi.

Metode pembelajaran digunakan lebih banyak bersifat lecturing yang diselingi dengan tanya jawab, satu metode penugasan kelompok dan diakhiri dengan model presentasi hasil piper kelompok.

Media dan sumber belajar yang disediakan berstandar ruangan belajar TIK berbasis internet, perpustakaan lengkap, ruangan belajar moderasi (bentuk $U$ dan 0) yang menempatkan whiteboard dan touch screen berlawanan, didukung dengan kursi putar mobile dan meja belajar utuh satu lingkaran, serta perangkat litrik yang safety on.

Pemateri (narasumber) adalah professor dan asisten professor (Dr.) dalam bidang teacher training atau memiliki kompetensi dibidang pendidikan berasal dari NUEPA Delhi India, yaitu: 
a. Overview Program by Prof. Najma Ahtar

b. Role of Emis in India by Prof. Arun C. Mehta \& Mr. Naveen Bhatia

c. Introduction to Group Work on Issues Related to Teaching by; Dr. B. K. Panda, Dr. Veera Gupta \& Dr. Mona Sedwal

d. Educational of Planning in India by Prof. S.M.I.A. Zaidi

e. Recent Developments in Higher Education by Prof. M.M.Ansari

f. Financing of Education in India by Prof. J.B.G.Tilak

g. Role of School Leadership by Dr. Rasmi Diwan

h. Vocational Educational and Skill Development in India by Dr. Y. Joshepine

i. Global Initiatives in Education by Prof. N.V. Varghese

j. Madarsa Education in India by Prof. Akhtar Siddiqui

k. ICT in Education: past, present and the Future by Prof. M. M. Pant

l. Innovations in Secondary Education by Dr. Veera Gupta

m. Search Document NUEPA by Prof. A Mathew

n. Teacher Managemen by Dr. Mona Sedwal

o. Importance of this Age group by Dr. Savita Kaushal

p. Education Administrasi in India by Prof. K. Sujatha

Narasumber memenuhi tentative time table yang dialokasikan dan sedik terjadi pergeseran waktu disebabkan oleh factor keterlambatan kedatangan peserta short course dari Jakarta-Indonesia yang bergeser 3 hari yaitu 14 s.d. 17 November 2013. 
Secara umum pembelajaran berjalan interaktif. Peserta cukup aktif mengikuti satu demi satu paparan narasumber, melakukan respons terhadap berbagai pandangan para Professor. Walaupun tidak dapat dipungkiri adanya beberapa peserta mengalami kendala penguasaan english pronunciation India yang relative.

Seluruh peserta aktif mengikuti pembelajaran dengan menerapkan standar disiplin, kerapian pakaian berciri khas culture Indonesia, tetap pada koridor sosialitas dalam kolegialitas sebagai ciri khas pelajar Indonesia.

Pada malam hari setelah makan malam (dinner) dilaksanakan meeting untuk me review pembelajaran sebagai bahan pembuatan laporan harian.

\section{Kunjungan Lapangan}

Di samping pembelajaran di kelas, peserta short course diajak berkunjung kebeberapa universitas, institut dan sekolah yang menyelenggarakan model teacher training sebagai berikut:

a. NIOS (National Institut of Open Schooling) Noida

Satu institut yang terletak di Institutional Area Opposite Jaipuria Noida. Dalam kunjungan ini kami mendapatkan gambaran terkait dengan aplikasi teaching trainer dari Prof. Kuldeep Agarwal dengan topic Teaching Education in Open Schooling suatu konsep yang dikembangkan oleh NIOS.

Prof. S. Bharadwaj Direktor NIOS dalam sambutannya menyampaikan ucapan terima kasih dan penghargaan atas kunjungan peserta short course Indonesia dan telah menjawab berbagai pertanyaan peserta short course terkait dengan konsep taching trainer yang berbasis open schooling.

Hal-hal pokok yang didapat pada kunjungan ini yaitu: 
1) Penerapan metode pelatihan dengan mengutamakan praktek

2) Penataan kelas moderasi seimbang rasio jumlah peserta

3) Media pembelajaran berbasis TIK lengkap

4) Fasiltas pendukung pembelajaran yang modern

5) Fasilitator (dosen) yang spesialis

b. Jamia Milia Islamia Delhi

Kunjungan kedua peserta shourt course yaitu di Departemen of Education Jamia Islamia Delhi yang diterima oleh Dekannya Prof. Ahrar Husein.

Dalam sambutannya Prof. Ahrar Husein memberikan penjelasan bahwa dalam Departemen Of Education Jamia Islamia Teaching Trainer disebutnya sebagai Teaching Education yaitu suatu profesi keguruan yang bertugas sebagai pelatih bagi mereka yang dipersiapkan untuk bekerja.

Rasa gembira dan hormat Dekan Departemen Of Education Jamia Islamia Prof. Ahrar Husein dan beberapa Profesor lainnya menyambut peserta short couse dengan teh hangat dan roti india sambil sesekali melemparkan pertanyaan terkait tujuan kunjungan. Dan pada akhir kunjungan berpose di depat pintu gerbang Dean Office Faculty of Education J.M.I. sebagai dokumen.

Hal-hal pokok yang didapat pada kunjungan ini yaitu:

1) Pendidikan untuk semua

2) Pembelajaran berbasis perpustakaan modern

3) TIK menjadi factor kelengkapan utama pembelajaran

4) Fasiltas pendukung pembelajaran yang sederhana

5) Dosen sesuai konsentrasi bidang formalnya 


\section{c. SCERT and DIET Gurgaon}

Kunjungan peserta short course selanjutnya di SCERT and DIET Gurgaon yaitu institute yang menerapkan program dan aktifitas persekolahan dalam model teacher training.

Peserta short course disambut dengan memberi tanda merah di kening sebagai lambing penghormatan dan penghargaan suatu bentuk tradisi (Hindi culture),

Head SCERT and DIET Gurgaon Prof. Anita Satia memaparkan program dan aktifitas persekolahan dan model teacher training, menurutnya bahwa model persekolahan yang bertumpu pada banyak pelatihan akan member dampak pemahaman dan pembentukan keterampilan yang lebih baik dari pada model pemberian materi yang bersifat tatap muka.

Beberapa contoh hasil kreatifitas anak ditunjukkan dengan berbagai prodak mengacu pada mata pelajaran, kearifan local dan kreatifitas berfikir global. Dan hal ini menjadikan pembelajaran lebih bermakna. Pendidikan life skill untuk mempersiapkan generasi muda india tetap pada konteks kemandirian (swadesi).

Kunjungan diakhiri dengan foto bersama didepan pintu gerbang SCERT and DIET Gurgaon beserta head, staf professor dan mahasiswa.

Hal-hal pokok yang didapat pada kunjungan ini yaitu:

1) Pembelajaran praktek berbasis kearifan lokal

2) TIK menjadi kelengkapan pembelajaran

3) Fasiltas pendukung sangat sederhana

4) Fasilitator sesuai spesifikasi bidang formalnya

5) Penerapan ide pembelajaran kemandirian

6) Lebih bersifat Hindi cultute 
7) Pemanfaatan limbah produktif

8) Menonjolkan karya seni

\section{Rekreasi}

Short course tidak saja dalam bentuk pembelajaran dan kunjungan namun diselingi juga dengan kegiatan rekreasi, bertujuan untuk refreshing dan lebih mendalami berbagai kondisi social masyarakat India serta sejarah kejayaan Islam di India.

Rekreasi pertama peserta short course menempuh perjalanan dari Hostel NUEPA Delhi menuju 2 tempat bersejarah yaitu Jama Masjid Delhi dan Red Fort Delhi.

a. Jama Masjid Delhi merupakan situs sejarah Dinasti Mughal pada kekaisaran Shah Jahan, dibangun pada tahun 1650 dan selesai tahun 1656, merupakan masjid terbesar dan yang paling dihormati oleh masyarakat India. Jama Masjid Delhi merupakan obyek wisata religi yang mengagungkan Islam di India. Jama masjid Delhi memiliki beberapa nama seperti; Masjid-i Jahān-Numā (Persian) Dan sering dikenal dengan nama Jama Masjid (Hindi dan Urdu).

b. Red Fort (benteng merah) juga merupakan situs sejarah Dinasti Mughal pada kekaisaran Shah Jahan dibangun pada tahun 1857 yang dirancang oleh Ustad Ahmad seoarang arsitektur pada dinasti Mughal. Red Fort dikenal oleh masyarakat India sebagai Lal Qila (Hindi) pada abad 17 sebagai pertahanan dinasti Mughal. Sekarang merupakan situs sejarah Islam yang menjadi tempat wisata terkemuka di Delhi India.

Itulah sebabnya telah menarik pengunjung dari berbagai belahan dunia untuk menyaksikannya. 
UNESCO pada tahun 1983 mahakarya yang dibangun dengan memadukan gaya arsitektur Persia, Turki, Islam, dan India menjadikannya sebagai Situs Warisan Dunia (the 7 wonders).

c. Taj Mahal secara historis dibangun Kaisar Mogul ke lima Kaisar Shan Jahan antara tahun 1631-1648 untuk mengenang Arjuman Bano Begum atau lebih dikenal sebagai Mumtaz Mahal.

Pada awalnya Shan Jahan hanya menyebut bangunan itu sebagai makam Mumtaz Mahal namun akhirnya berkembang menjadi Taj Mahal. Taj Mahal jika diterjemahkan berarti "Istana Mahkota", sebuah perluasan dari nama Mumtaz Mahal yang berasal dari Persia.

Taj Mahal merupakan bangunan yang didesain berasal dari bentuk tradisi seni Persia dan seni Mughal awal. Inspirasi khusus datangnya dari Dinasti Timurid dan bangunan Mughal termasuk Gur-e Amir (makam Timur, penggagas dinasti Mughal, di Samarkand), makam Humayun, Makam Itmad-Ud-Daulah (yang disebut sebagai Bayi Taj), dan Masjid Jama (Jama Masjid di Delhi). Sementara bangunan Mughal awal biasanya dibangun dari batu pasir merah, Shah Jahan menganjurkan penggunaan marmer putih dihias dengan batu separa bernilai, dan bangunan di bawah naungannya mencapai tahap kehalusan sempurna.

d. Agra Fort atau Benteng Agra juga termasuk dalam daftar Situs Warisan Dunia oleh UNESCO. Letaknya di pusat kota Agra, tepatnya di dua setengah kilo barat laut Taj Mahal. Benteng ini merupakan bangunan penting bersejarah bagi Kerajaan Mughal, didirikan pada awal abad ke limabelas Masehi.

Pembangunan secara besar-besaran baru dilakukan sejak zaman kepemerintahan King Akbar pertama di tahun 1565, butuh delapan 
tahun untuk menyelesaikan pembangunan benteng ini, seorang Qasim Khan Mirr Barr-ur Bahr dipercaya kerajaan untuk mengawasi jalannya proyek pembangunan benteng ini. Biaya pembangunannya konon menelan 35 lakh Rupees.

Setelahnya renovasi dan pengembangan wilayah benteng ini terus dilanjutkan oleh generasi keturunannya seperti Raja Jehangir Mahal, hingga Shah Jahan.

Monumen Agra Fort merupakan bangunan terpenting dalam sejarah Mughal, tercatat semua keturunan Mughal, dari King Akbar, Raja Jehangir, Shah Jahan, hingga Aurangzeb menempati benteng ini sebagai istana mereka.

Bangunan Agra Fort ini dominan dengan material batu bata merah dan batuan berjenis marmer. Dalam luas areal dua setengah kilometer tersebut, Agra Fort dihuni oleh beberapa bangunan penting kerajaan di dalamnya. Terdapat istana-istana milik Raja, diantaranya Akbari Mahal, Shah Jahani Mahal, Jehangiri Mahal, Khas Mahal, Shish Mahal, hingga beberapa ruangan penting khas kerajaan seperti Diwan-i-Khas, Diwan-i-am, Machchhi Bhawan, Mayura Mandapa, terdapat juga beberapa masjid didalam benteng ini, seperti Moti Masjid, Mina Masjid, dan Nagina Masjid, dengan beberapa taman dan air mancur yang sangat arsitektural, Anquri Bagh dan Mussaman Burj.

Seni kaligrafi Islami mendominasi dinding-dinding benteng ini, sebagian warna biru pada dinding ini sudah pudar karena tergerus zaman, tetapi struktur bangunannya masih terlihat sangat kokoh. Benteng merah ini punya nama dan struktur bangunan utama yang sama dengan Lal Qila atau The Red Fort yang ada di Delhi. Benteng 
Agra ini disebut-sebut sebagai sister of Taj Mahal, letak keduanya saling berdekatan, diantara keduanya terbentang aliran sungai Yamuna.

Pada saat zaman King Akbar dulu, letak benteng ini berada dibibir sungai Yamuna, beberapa ghat dibangun sebagai portal untuk aktivitas perdagangan dari luar kota. Terdapat dua pintu gerbang utama untuk mengakses ke dalam benteng ini, Delhi Gate dan Amar Singh Gate, tetapi umumnya para pengunjung dilokasikan ke pintu gerbang Delhi Gate.

\section{Permasalahan dan Alternatif Pemecahan}

Secara umum short course widyaiswara pada NUEPA Delhi India tahun 2013 telah dapat berjalan dengan baik. Namun demikian tentu ada saja halhal yang menjadi permasalahan, seperti:

a. Kurang matangnya persiapan keberangkatan

b. Kurang maksimalnya pendampingan agen (negosiator)

c. Kurangnya penguasaan bahasa Inggris

d. Kurangnya informasi terkait lokasi tempat short course

e. Kurangnya dana pembiayaan short course

Berdasarkan permasalahan di atas, maka alternative pemecahan yang dapat dilakukan tidak lain dengan meningkatkan koordinasi lintas instansi (stakeholder), membuat model evaluasi penjaringan dan menyesuaikan anggaran berdasarkan kurs rupiah terhadap dolar (mata uang yang berlaku). 


\section{Penutup}

1. Simpulan

Secara umum short course widyaiswara pada NUEPA Delhi India tahun 2013 telah berjalan dengan baik dan dapat meningkatkan kompetensi widyaiswara berbasis pengembangan dan peningkatan pengetahuan substantive teacher training perspektif NUEPA Delhi India.

Widyaiswara (peserta short course) juga mendapat pengetahuan dan pengalaman berwawasan internasional, mengeksplorasi social budaya masyarakat India, menapaki situs sejarah kejayaan Islam di India, dan beradaptasi dengan tatanan kehidupan masyarakat India yang sederhana.

Berbagai permasalahan yang dihadapi dapat dipecahkan dengan berbagai langkah alternatif sehingga tidak menjadi kendala dalam pelaksanaan short course.

\section{Rekomendasi}

Memperhatikan demikian besar manfaat yang diperoleh dari kegiatan short course ini maka perlu diajukan beberapa rekomendasi sebagai berikut:

a. Kepada Kepala Badan Litbang dan Diklat Kementerian Agama R.I. kiranya berkenan mengeluarkan kebijakan agar kegiatan short course bagi widyaiswara dilaksanakan di tahun yang akan datang;

b. Kepada Sekretaris Badan Litbang dan Diklat Kementerian Agama R.I. kiranya berkenan meningkatkan anggaran dan volume kegiatan short course bagi widyaiswara di tahun yang akan datang, mencari fasilitator (negosiator) yang kompeten serta lokasi yang relevan dan kridible; 
c. Kepada para pimpinan unit kerja kediklatan (Pusdiklat dan BDK) untuk berkenan mendukung sepenuhnya kegiatan short course bagi widyaiswara;

d. Kepada widyaiswara peserta short course NUEPA Delhi India Tahun 2013 untuk mensosialisasikan hasil kepada pimpinan dan rekan widyaiswara serta dapat menerapkannya dalam unit kerja masingmasing. 
FOTO KEGIATAN

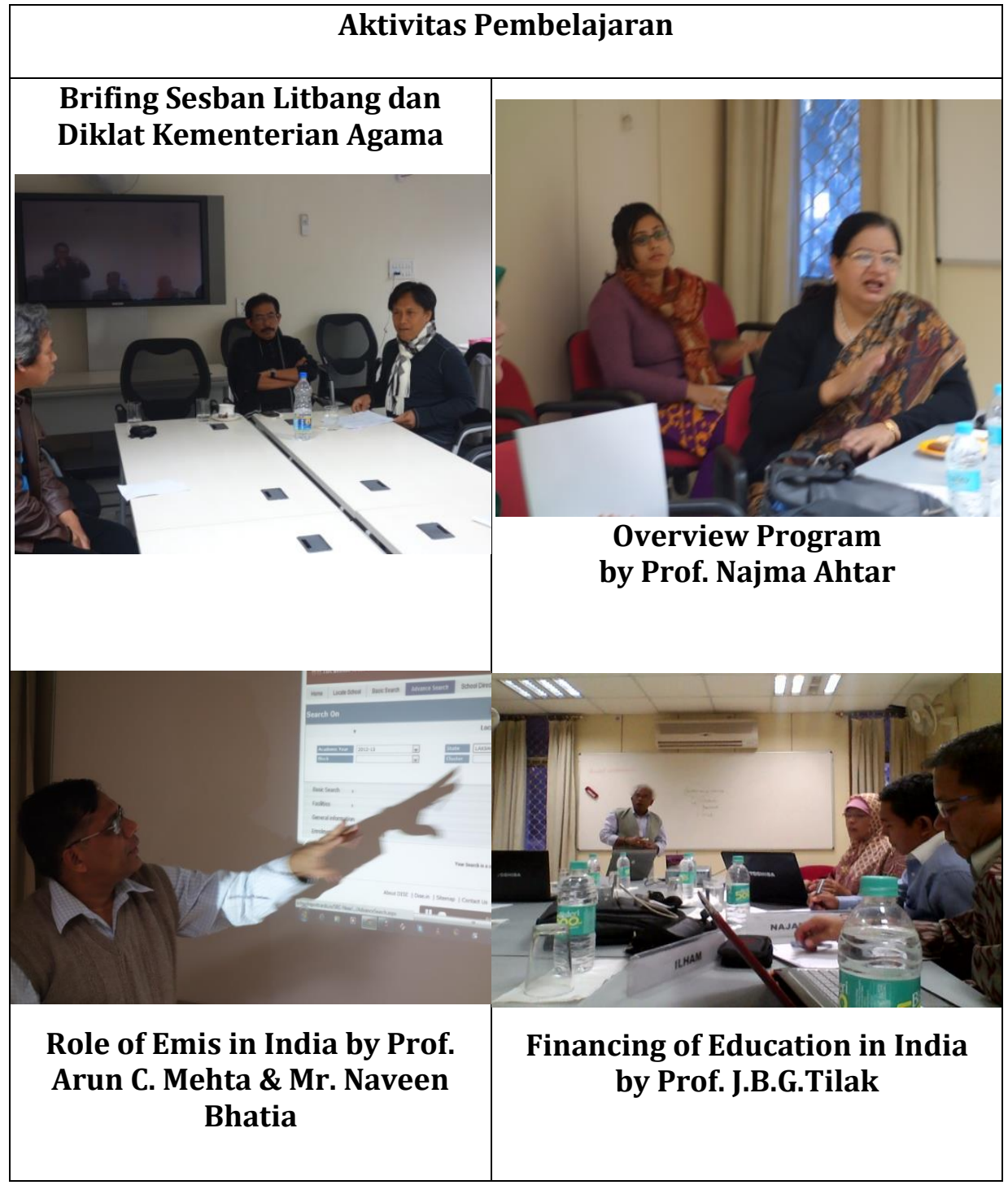




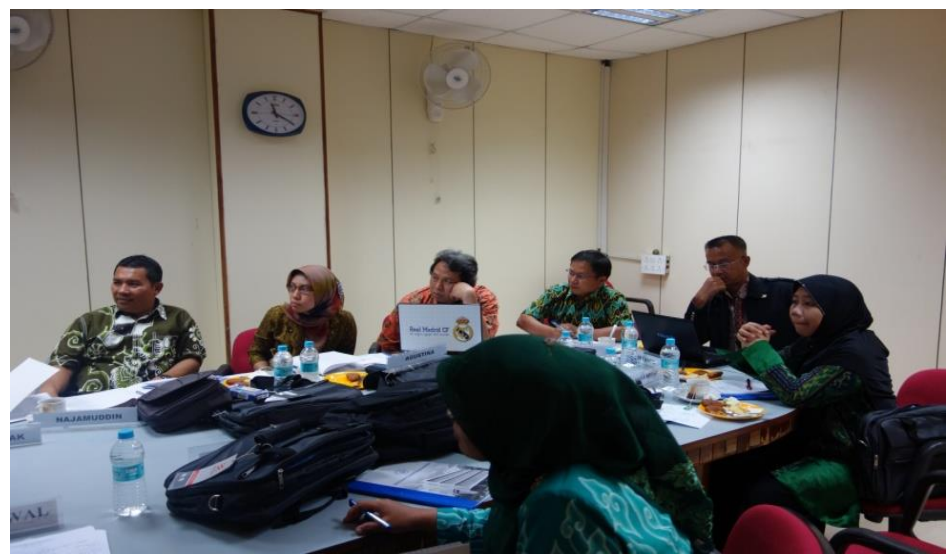

Peserta sedang serius mengikuti paparan dari professor (narasumber) ruang belajar eksekutif NUEPA.

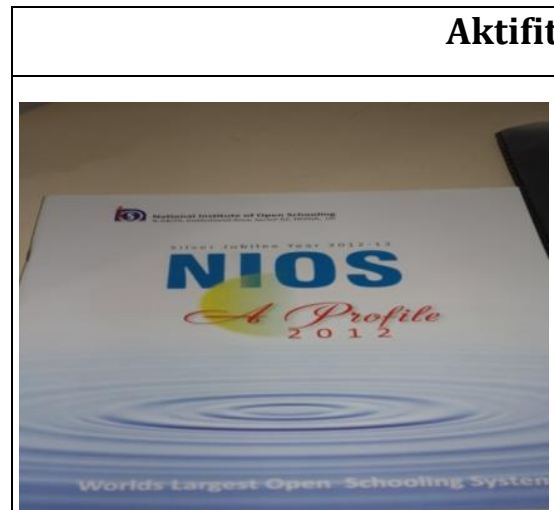

NIOS (National Institut of Open Schooling) Noida

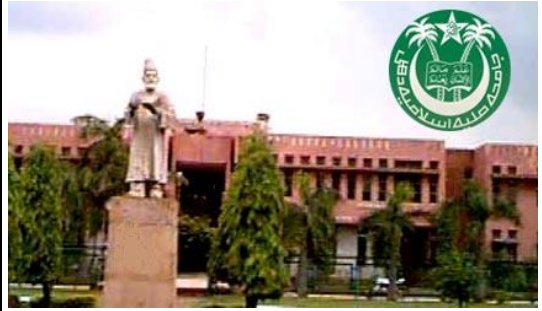

Jamia Milia Islamia Delhi

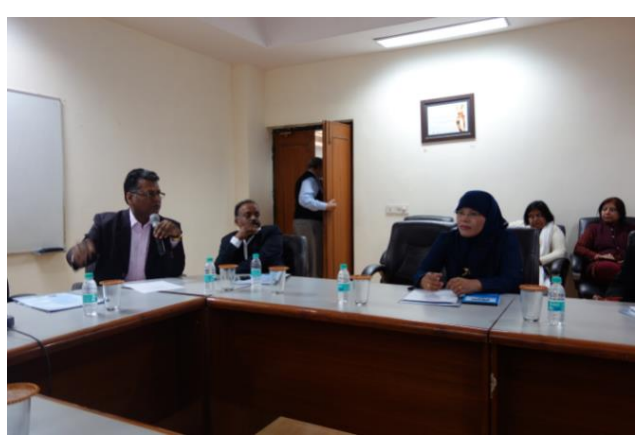

Prof. S. Bharadwaj (Direktor NIOS) sedang menjawab pertanyaan peserta Short Course

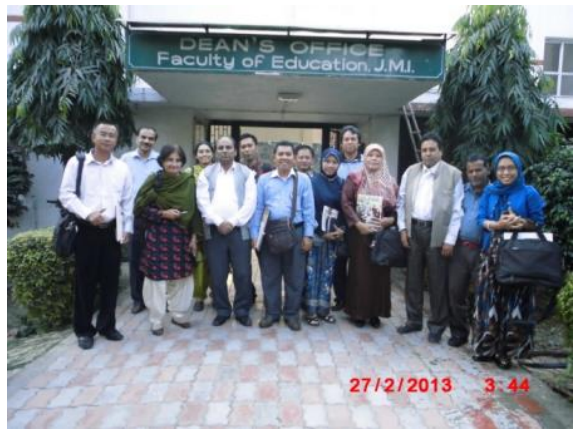

Prof. Ahrar Husein dan beberapa Prof. beserta peserta short couse berpose di depat pintu gerbang 


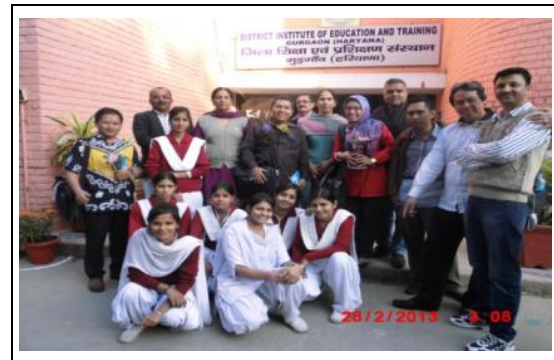

Foto bersama didepan pintu gerbang SCERT and DIET Gurgaon beserta head, staf professor dan mahasiswa

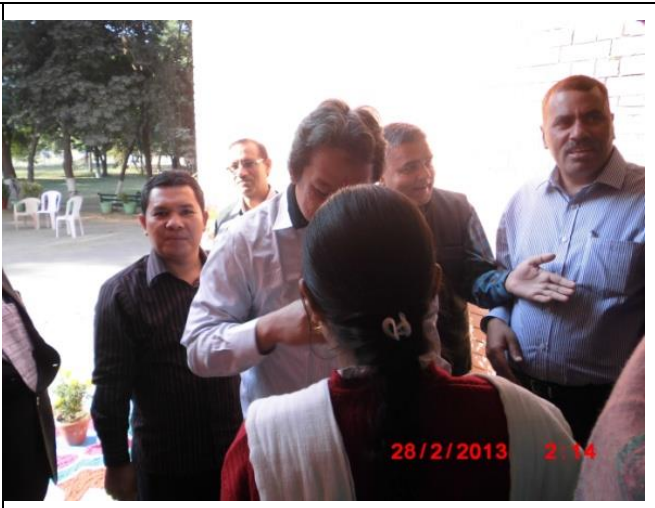

Aktivitas Rekreasi

\section{Red Fort Delhi India}

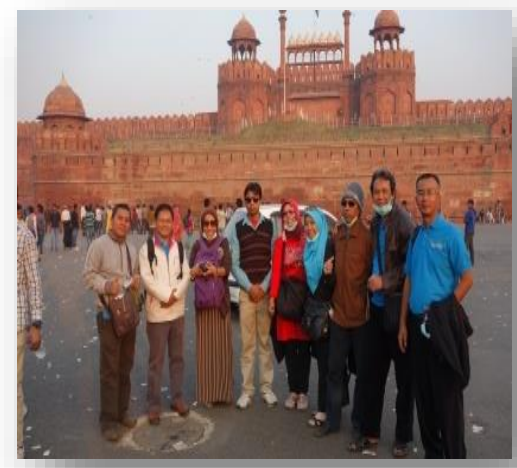

Jama Masjid Delhi India

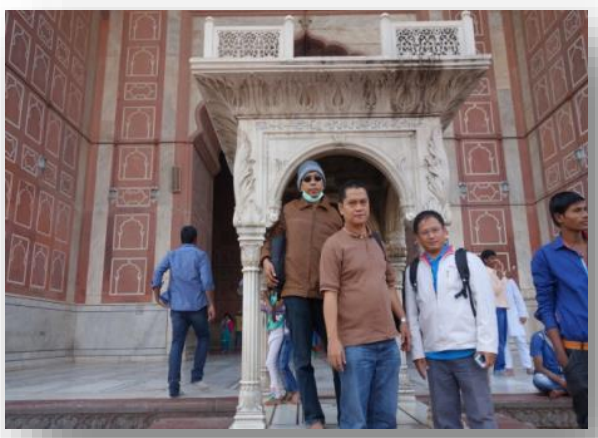




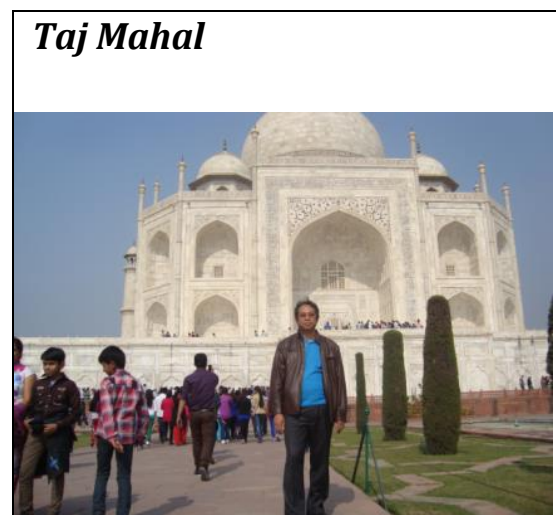

\section{Agra Fort}

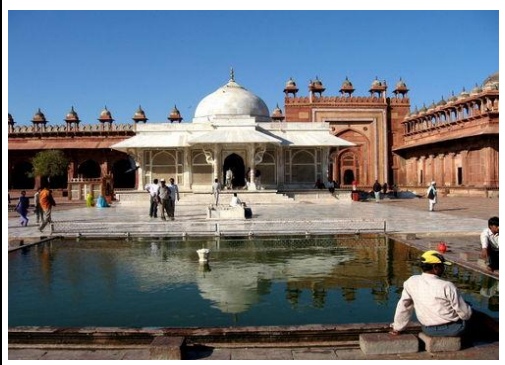

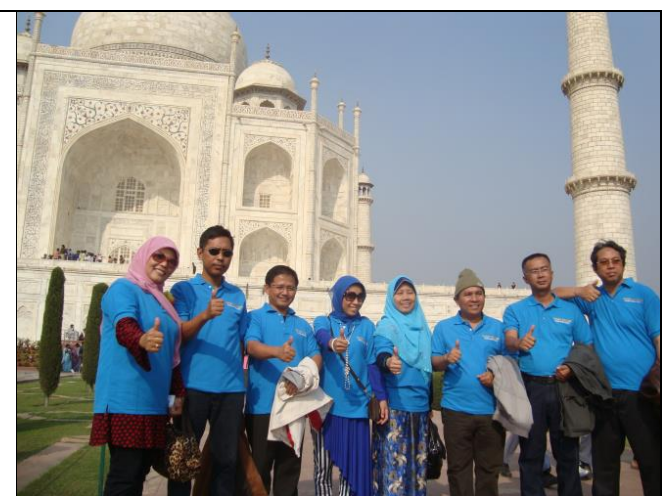

Taj Mahal

Agra Fort

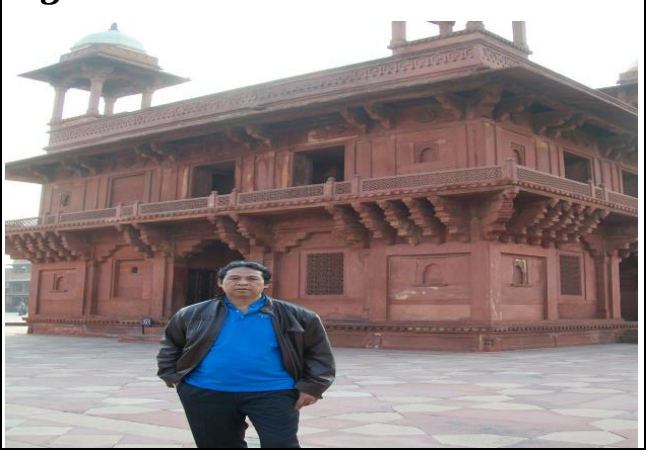




\section{BAGIAN IX}

\section{PESONA WARISAN KEJAYAAN ISLAM DI INDIA}

Kesempatan yang saya peroleh bulan Nopember 2013 untuk melaksanakan tugas Short course dari Instansi tempat saya bekerja sangat saya sambut gembira, karena terlintas di benak saya untuk dapat menggunakan kesempatan di waktu senggang berkunjung ke tempat bersejarah warisan kejayaan Islam di India. Alhamdulillah, pihak National University of Educational Planning and Administration (NUEPA) yang merupakan pihak penyelenggara memahami keinginan peserta short course. Jadwal kegiatan yang disusun selain dalam bentuk pembelajaran dan kunjungan ke sekolah dan lembaga pendidikaan di India diselingi juga dengan kegiatan rekreasi untuk refreshing dan lebih mendalami kondisi sosial masyarakat India serta sejarah kejayaan Islam di India.

Rekreasi pertama dengan mobil yang difasilitasi NUEPA, kami menempuh perjalanan selama 30 menit dari Hostel NUEPA menuju dua tempat bersejarah yaitu Jama Masjid dan Red Fort. Kedua tempat tersebut terletak di Old Delhi. Sebelum menuju ke Jama Masjid, kami melewati sebuah jalan yang berubah fungsi menjadi pasar tumpah dipenuhi pemandangan manusia yang berjubel, di mana di sana kami menyaksikan 
potret masyarakat tingkat bawah di Delhi. Mereka masih sangat tradisional, sederhana bahkan terkesan kurang bersih dan higienis. Hal ini dapat dipahami mengingat prinsip hidup sederhana (swadesi) sebagai kearifan sosial dan kuatnya pengaruh agama Hindu baik secara kultural maupun sosial yang menjadi agama mayoritasnya.

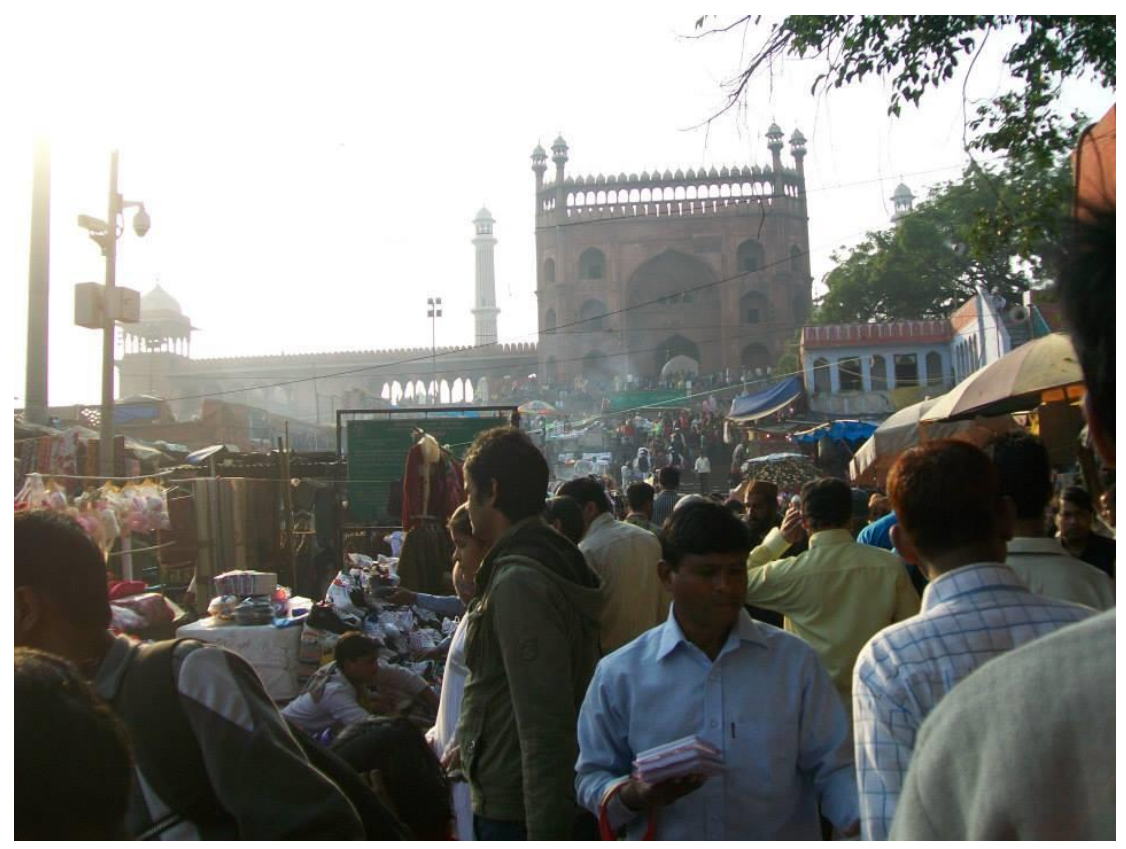

Gbr. Pemandangan Pasar Tumpah di sekitar Jama Masjid 


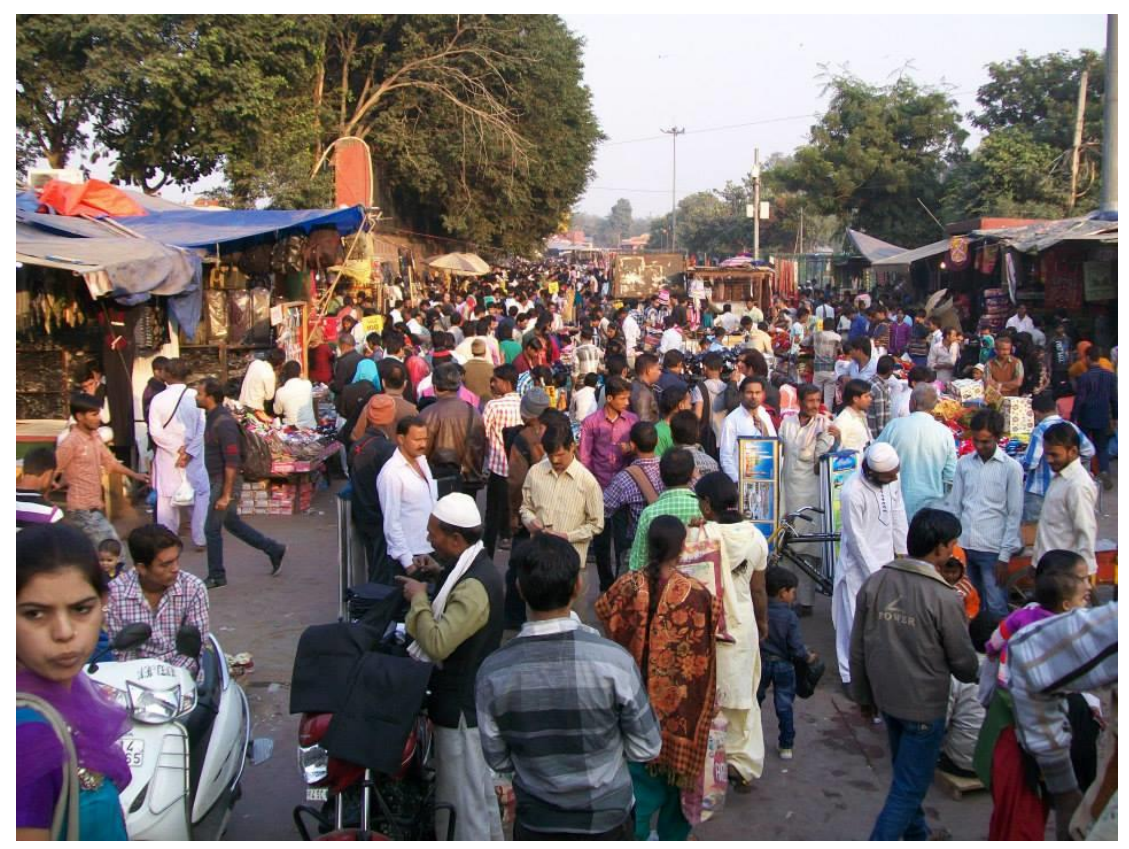

Gbr. Pemandangan Pasar Tumpah di sekitar Jama Masjid

Jama Masjid dibangun pada tahun 1650 dan selesai tahun 1656, merupakan masjid terbesar dan yang paling dihormati oleh masyarakat India. Konon mesjid ini adalah masjid utama di Old Delhi yang dibangun oleh Raja Mughal yang bernama Shah Jahan. Letak masjid ini berada di jalan Chawri Bazar Road yang luar biasa ramai. Guide kami yang bernama Naresh berkali-kali mengingatkan untuk tidak terpisah dari rombongan dan berhati-hati dengan tas yang kami bawa. Dan benar saja, jalan menuju mesjid ini luar biasa padat oleh pedangang da pengunjung pasar tumpah. Lautan manusia ini begitu banyak bahkan Naresh pun bingung sendiri harus lewat mana hingga jalannya berputar-putar. Lalu saat kami tiba di gerbang mesjid, kami harus membuka sepatu. Saya pikir di gerbang itu adalah batas suci untuk orang yang mau sholat hingga semua pengunjung 
harus melepas sepatu, ternyata tidak. Masuk ke dalam lingkungan mesjidnya tidak steril juga. Beberapa teman memutuskan sholat sedangkan kami yang sudah lebih dulu menjamak sholat di hostel hanya berada di luar masjid sambil melihat-lihat. Yang menarik adalah kawanan burung yang luar biasa banyak, hinggap di berbagai bagian masjid dan suara mereka begitu riuh.

Jama Masjid merupakan obyek wisata religi yang mengagungkan Islam di India. Jama Masjid memiliki beberapa nama seperti; Masjid-i JahānNumā (Persian) dan sering dikenal dengan nama Jama Masjid (Hindi dan Urdu). Nama Jama Masjid, konon diambil dari kata Jummah, sholat yang dilakukan tiap hari Jumat oleh Muslim. Mesjid ini bisa menampung 25. 000 jamaah, memiliki 3 gerbang besar, 4 menara yang bahannya adalah batu bata merah dan marmer putih. Raja Shah Jahan membangun beberapa masjid penting di Delhi, Agra, Ajmer dan Lahore, dan bisa dibayangkan betapa kayanya Raja ini. Namun sayang citra masjid yang harusnya steril tidak kami jumpai di Jama Masjid. Lingkungannya semrawut, pedagang dan masyarakat berjubel di sekitar area menuju masjid, dan kabarnya tingkat kriminalitas cukup tinggi di sana. Harapan kami mudah-mudahan Pemerintah setempat dapat menata kembali tempat bersejarah tersebut sehingga akan lebih rapi, bersih dan nyaman bagi pengunjung. 


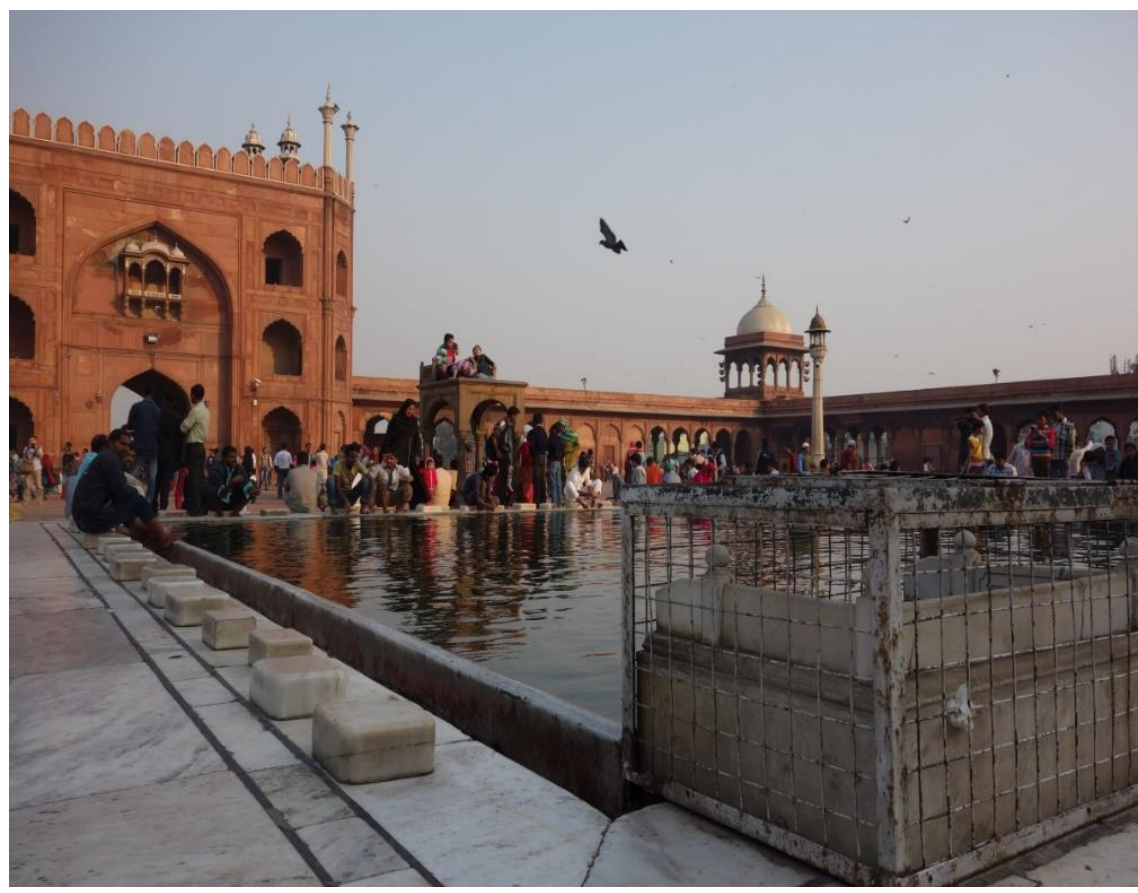

Gbr. Jama masjid

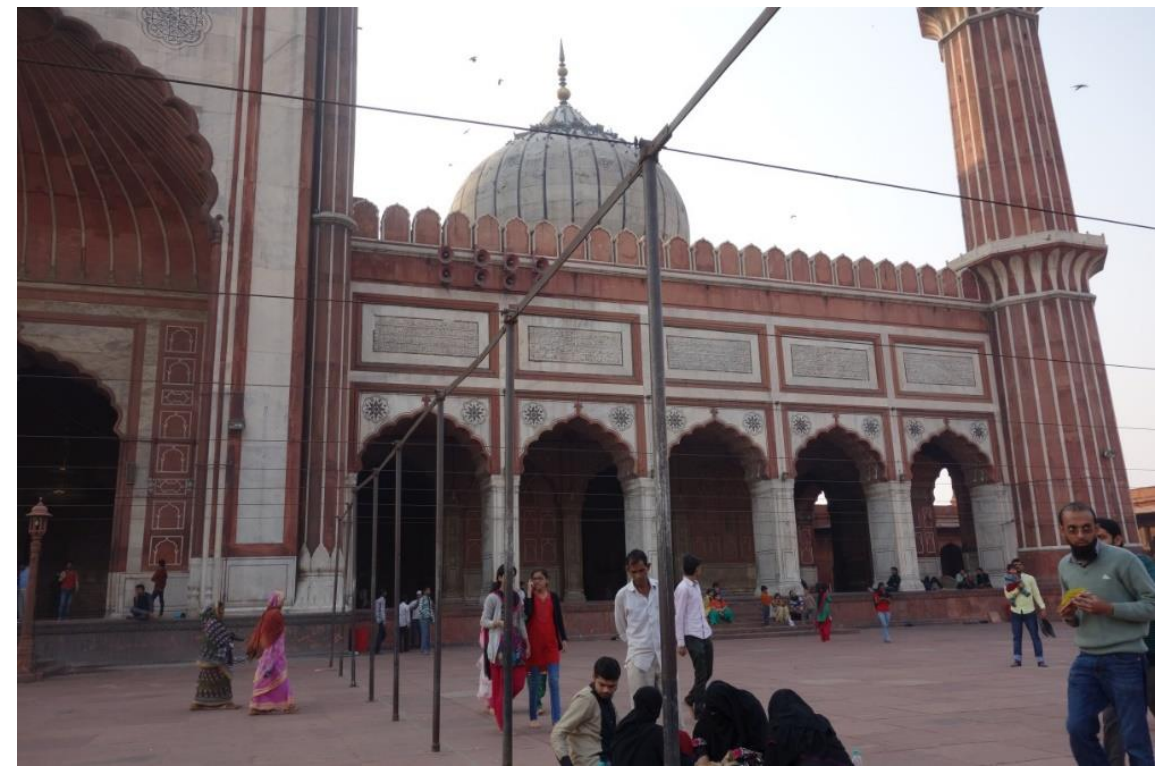




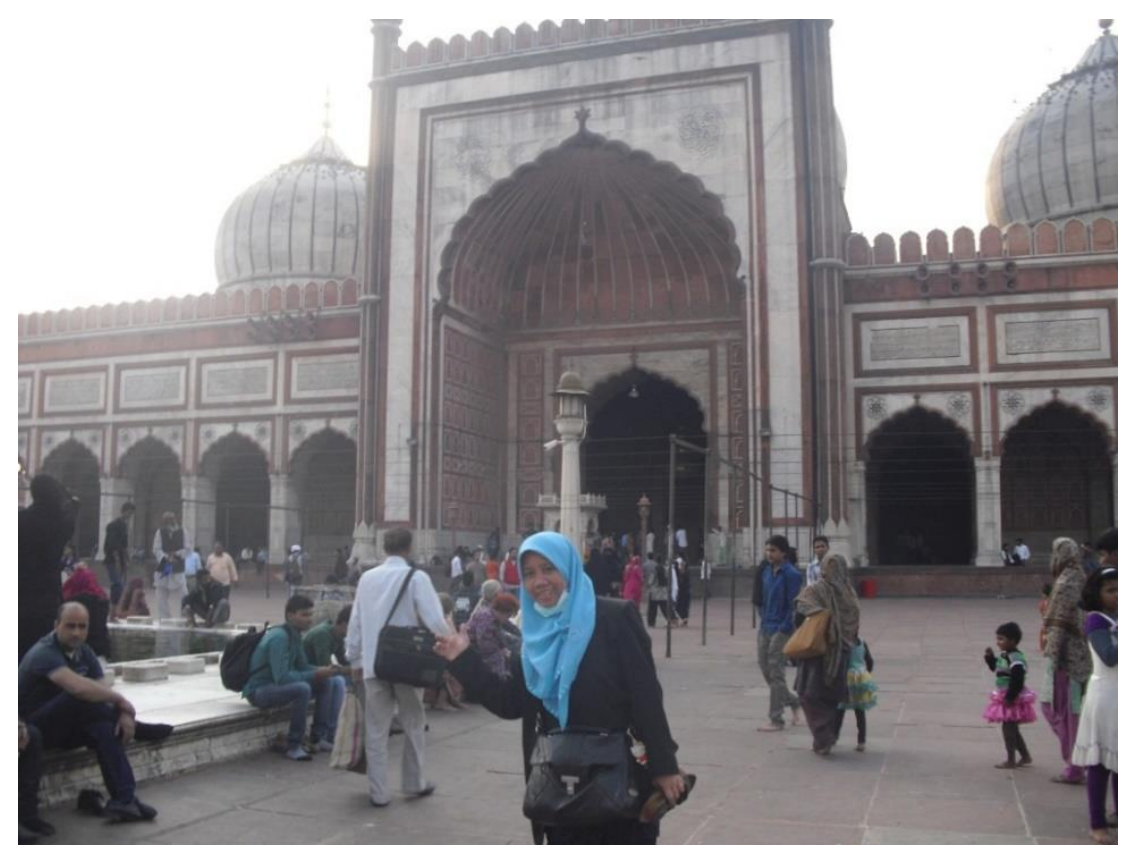

Gbr. Jama Masjid

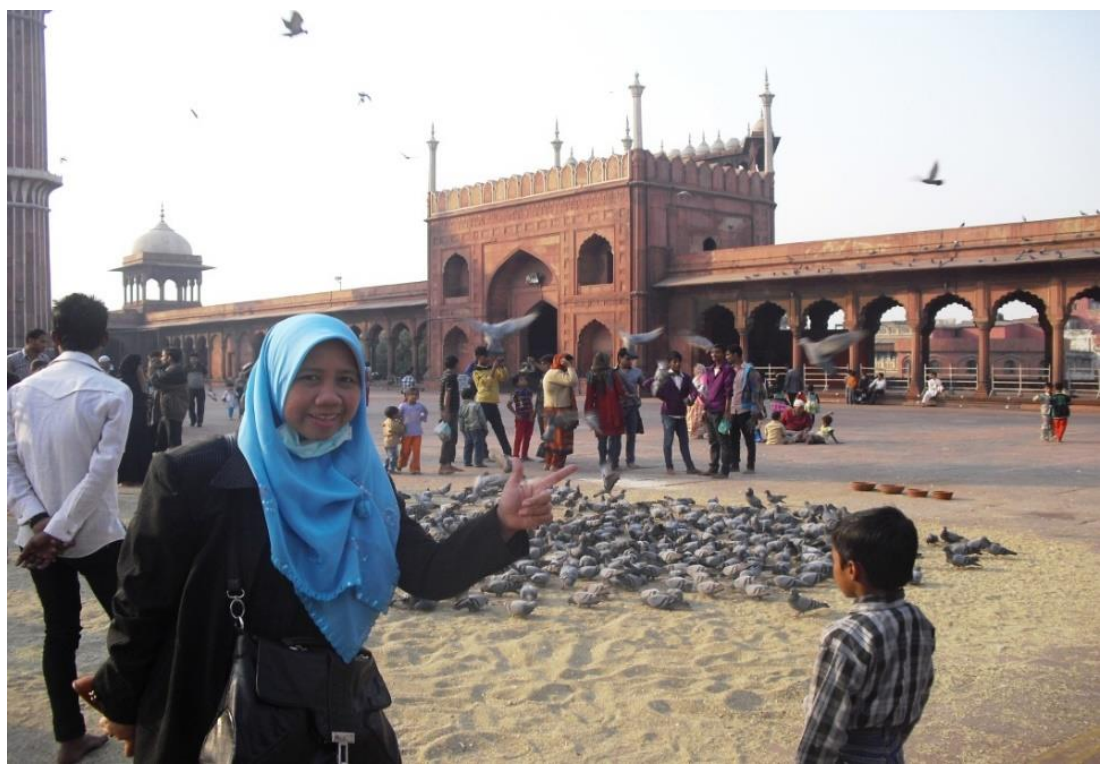

Gbr. Jama Masjid 


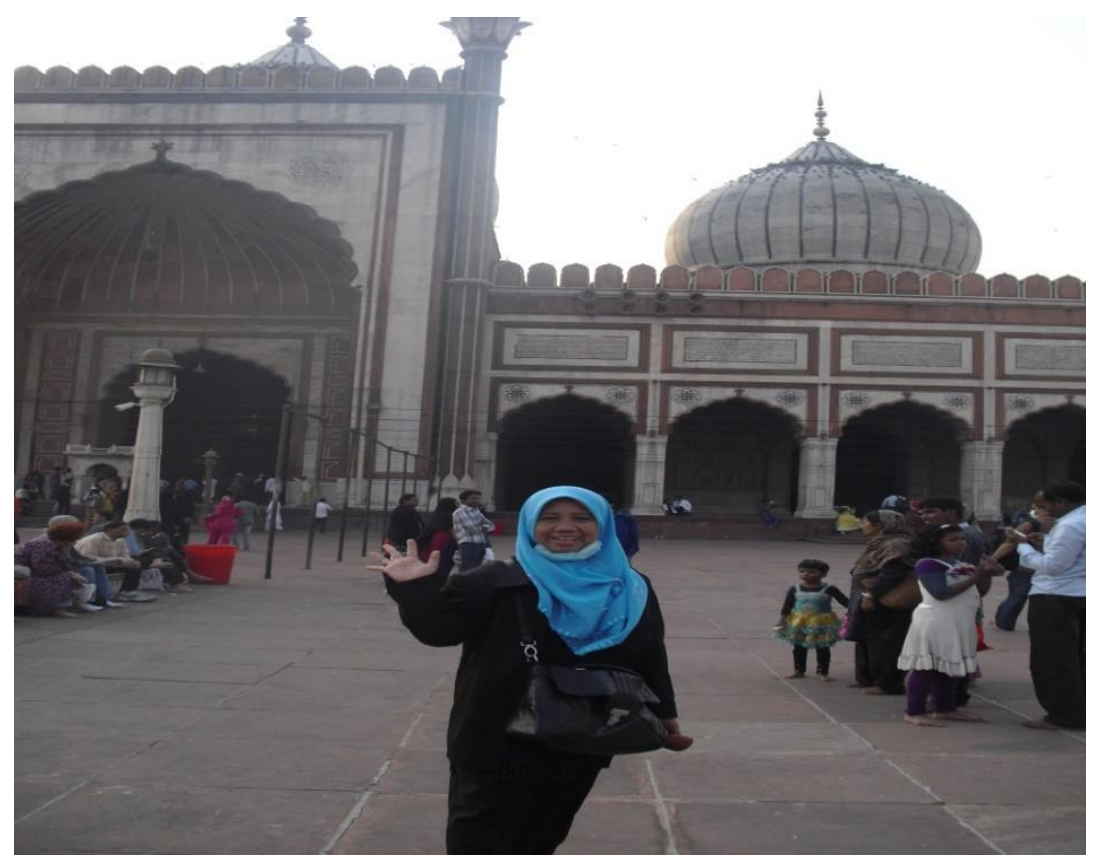

Gbr Jama Masjid

Tak jauh dari Jama Masjid, terletak Red Fort (benteng merah) yang juga merupakan situs sejarah Dinasti Mughal pada kekaisaran Shah Jahan. Benteng ini dibangun pada tahun 1857 yang dirancang oleh Ustad Ahmad seoarang arsitektur pada dinasti Mughal. Red Fort dikenal oleh masyarakat India sebagai Lal Qila (Hindi) pada abad 17 sebagai pertahanan Dinasti Mughal. Benteng ini merupakan situs sejarah Islam yang menjadi tempat wisata terkemuka di Delhi India. Red Fort sebagai mahakarya yang dibangun dengan memadukan gaya arsitektur Persia, Turki, Islam, dan India telah menarik pengunjung dari berbagai belahan dunia untuk menyaksikannya. Itulah sebabnya UNESCO pada tahun 1983 menjadikannya sebagai Situs Warisan Dunia (the 7 wonders). 


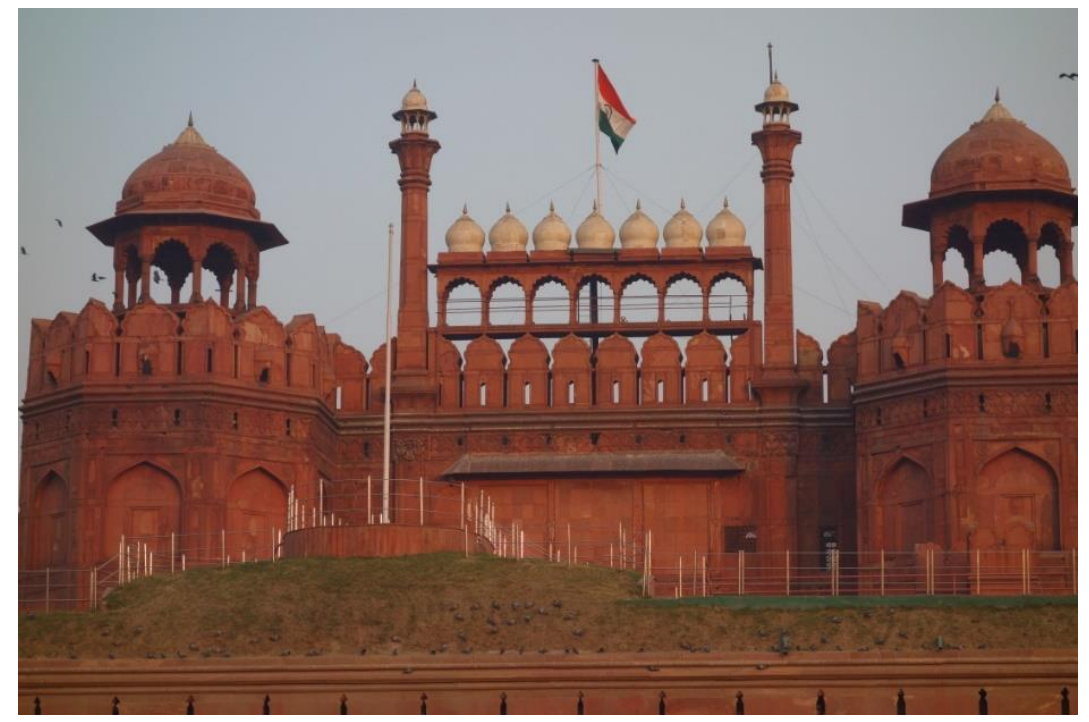

Gbr. Red Fort

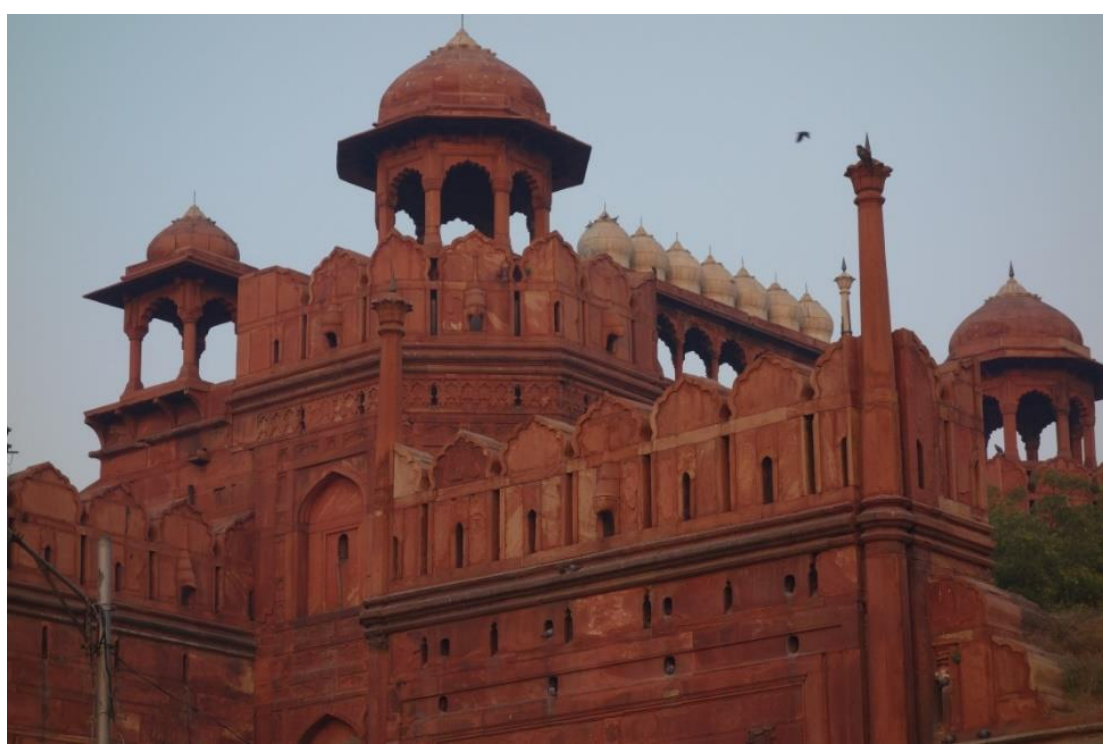

Gbr. Red Fort 


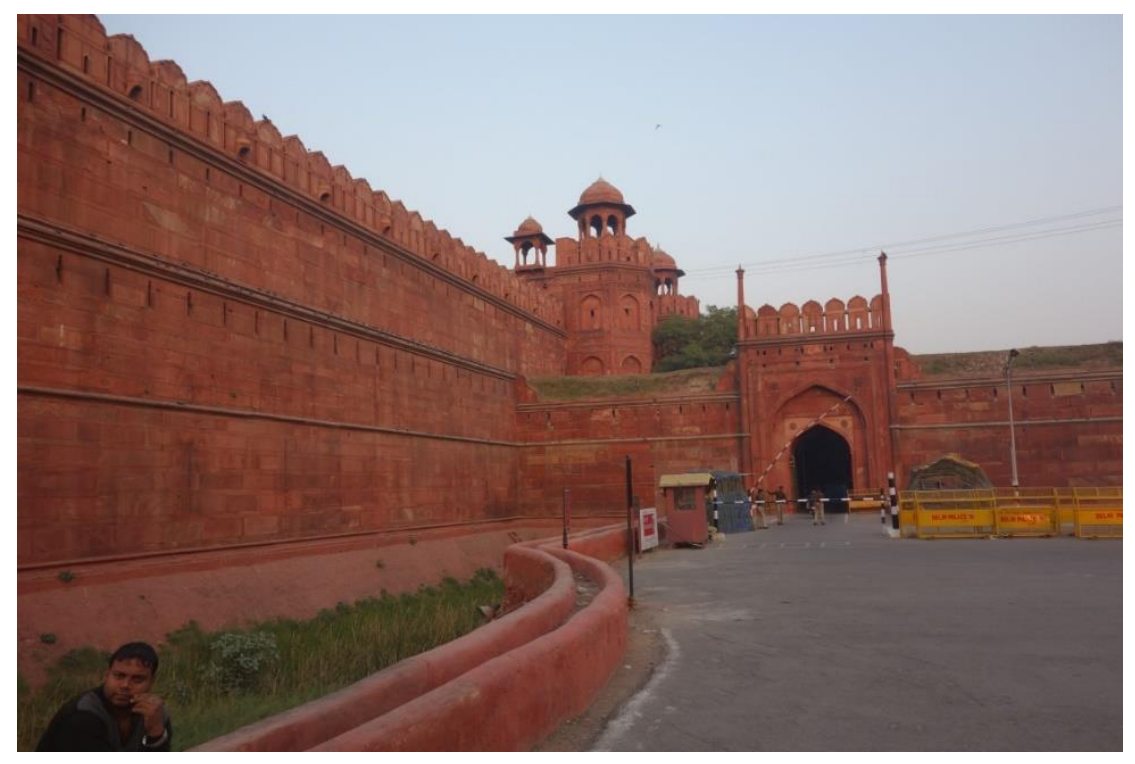

Gbr. Red Fort

Hari berikutnya, dengan bus besar yang difasilitasi oleh NUEPA kami menuju ke Taj Mahal. Perjalanan yang kami tempuh dari hostel NUEPA menuju Taj Mahal selama 4 jam tidak membuat kami lelah, karena kami memang sangat menantikan kunjungan ke salah satu dari tujuh keajaiban dunia ini. Sepanjang perjalanan kami menyaksikan pemandangan sungai Yamuna, serta kondisi masyarakat dan lalu lintas di India yang kami saksikan, misalnya mobil yang lalu lalang sangat cepat dan sering kali menekan klakson 


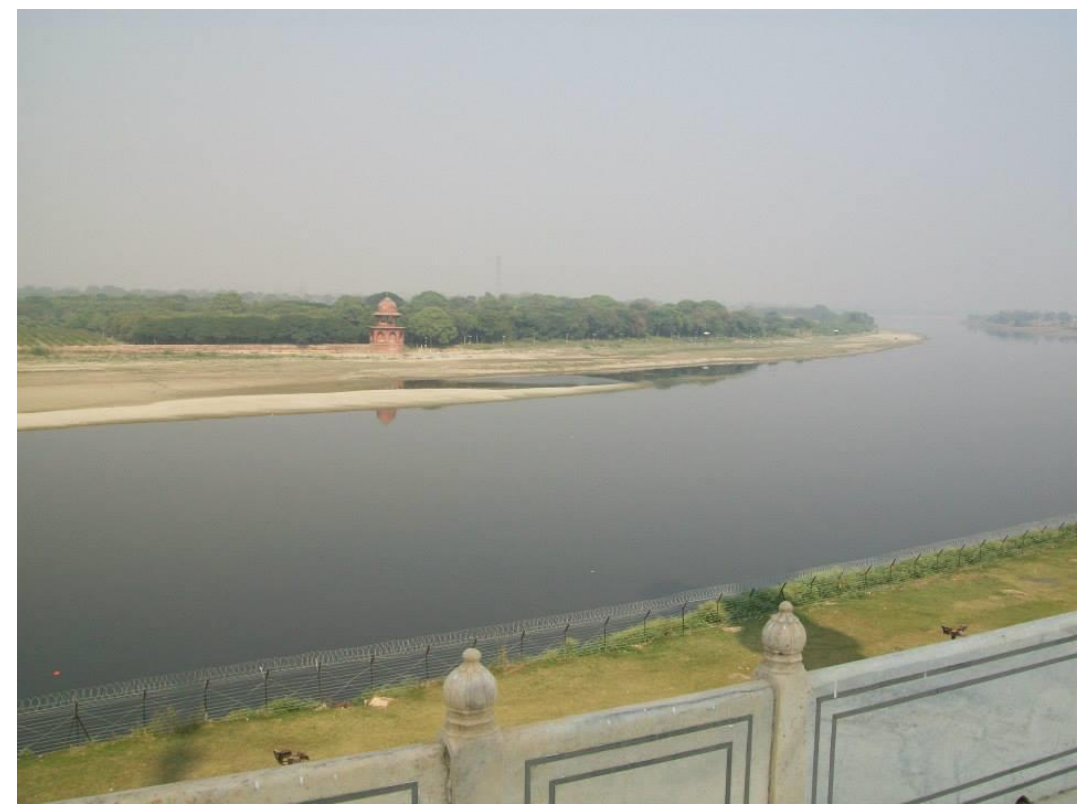

Gbr. Pemandangan sungai Yamuna dari Taj Mahal
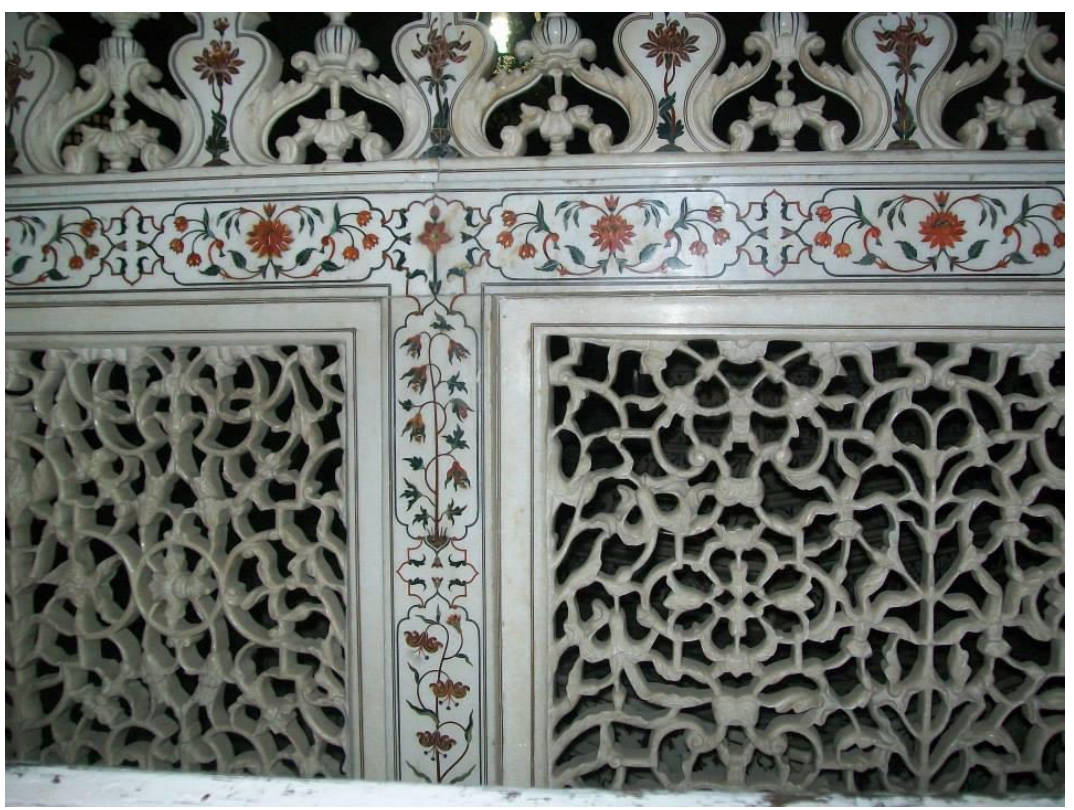

Gbr. Ukiran cantik di dalam Taj Mahal 
Untuk masuk ke Taj Mahal kami harus membeli tiket dan melewati pos penjagaan yang ketat. Ini menjadi bukti Pemerintah India memang sangat menjaga bangunan bersejarah ini. Selain itu Pemerintah India juga sangat membuka kesempatan kepada warga negaranya untuk dapat menambah wawasan dan kecintaan budaya lokal dengan berkunjung ke bangunan yang dibangun Kaisar Mogul kelima, Kaisar Shan Jahan ini. Terbukti dengan selisih harga tiket yang cukup tinggi antara tiket turis dengan tiket pengunjung domestik. Tiket masuk yang saya dan kawan-kawan saya beli ternyata lebih mahal, yaitu sebesar 750 rupee, dibandingkan dengan penduduk lokal, yang hanya sebesar 50 rupee.

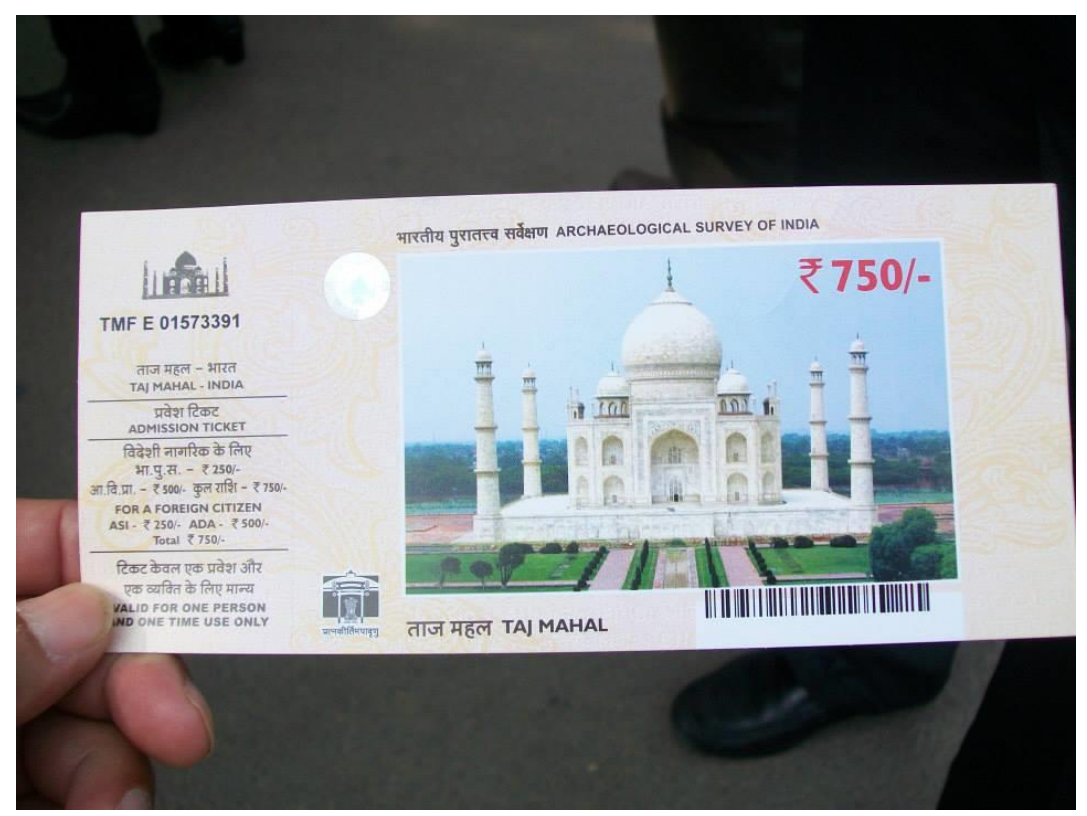

Gbr. Tiket masuk Taj Mahal untuk Turis 
Taj Mahal dibangun antara tahun 1631-1648 untuk mengenang Arjuman Bano Begum atau lebih dikenal sebagai Mumtaz Mahal. Pada awalnya Shan Jahan hanya menyebut bangunan itu sebagai makam Mumtaz Mahal namun akhirnya berkembang menjadi Taj Mahal. Taj Mahal jika diterjemahkan berarti "Istana Mahkota", sebuah perluasan dari nama Mumtaz Mahal yang berasal dari Persia.

Taj Mahal merupakan bangunan yang didesain berasal dari bentuk tradisi seni Persia dan seni Mughal awal. Inspirasi khusus datangnya dari Dinasti Timurid dan bangunan Mughal termasuk Gur-e Amir (makam Timur, penggagas dinasti Mughal, di Samarkand), makam Humayun, Makam Itmad-Ud-Daulah (yang disebut sebagai Bayi Taj), dan Masjid Jama (Jama Masjid di Delhi). Sementara bangunan Mughal awal biasanya dibangun dari batu pasir merah, Shah Jahan menganjurkan penggunaan marmer putih dihias dengan batu separa bernilai, dan bangunan di bawah naungannya mencapai tahap kehalusan sempurna.

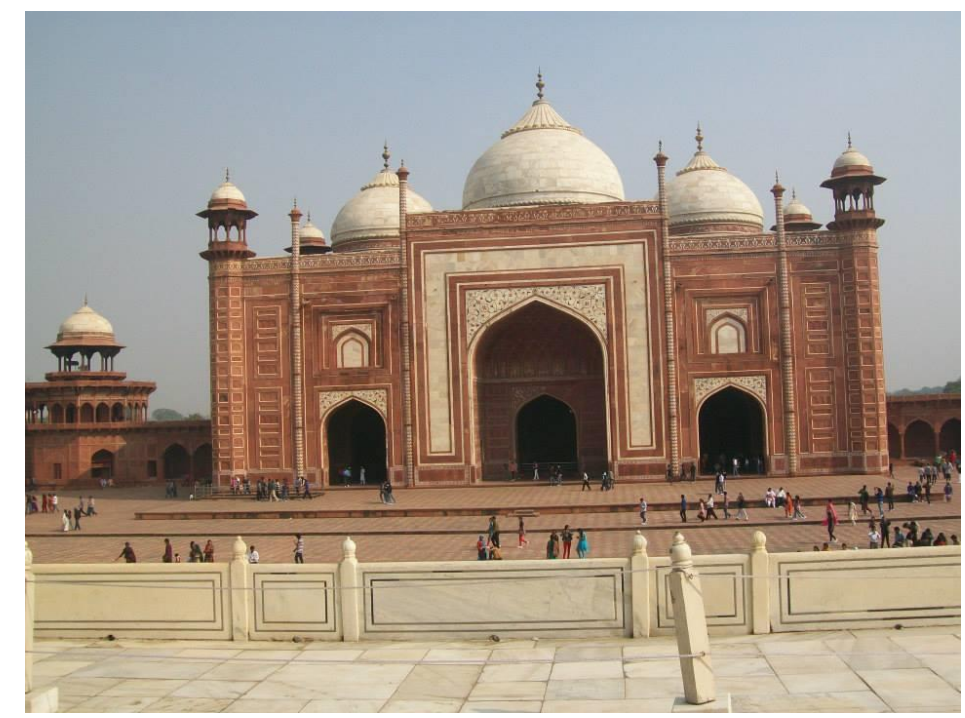

Gbr. Pintu Gerbang Taj Mahal yang berwarna merah 


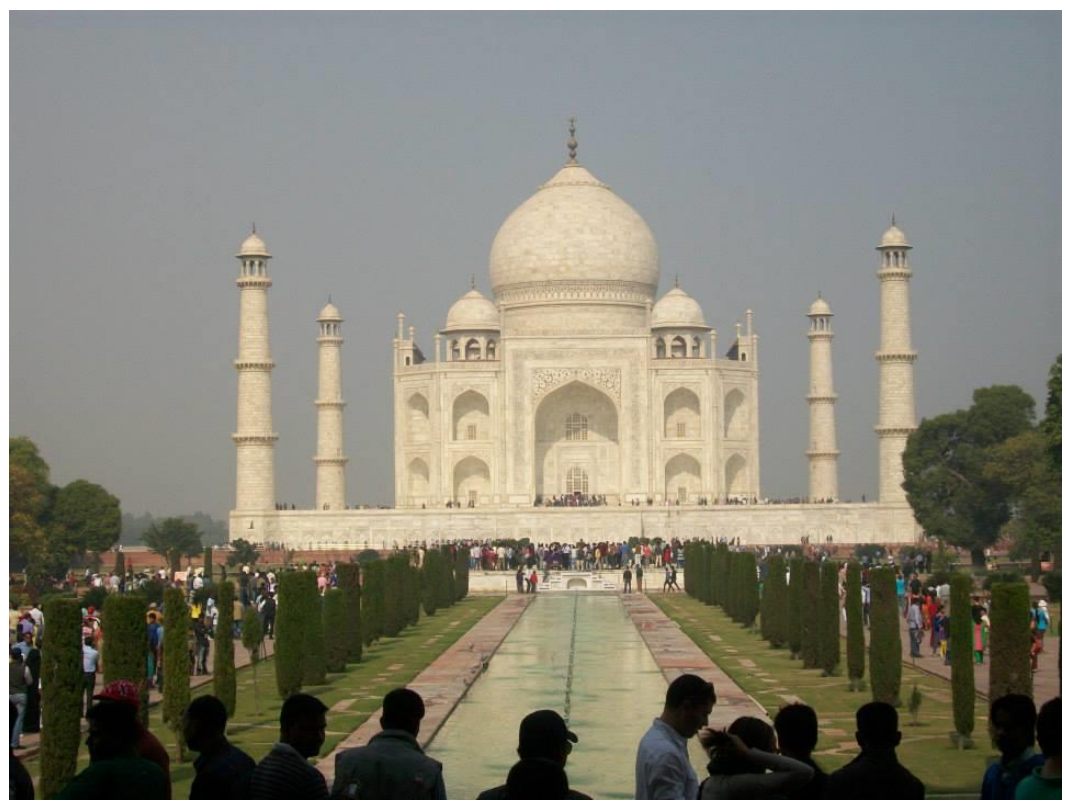

Gbr. Taj Mahal

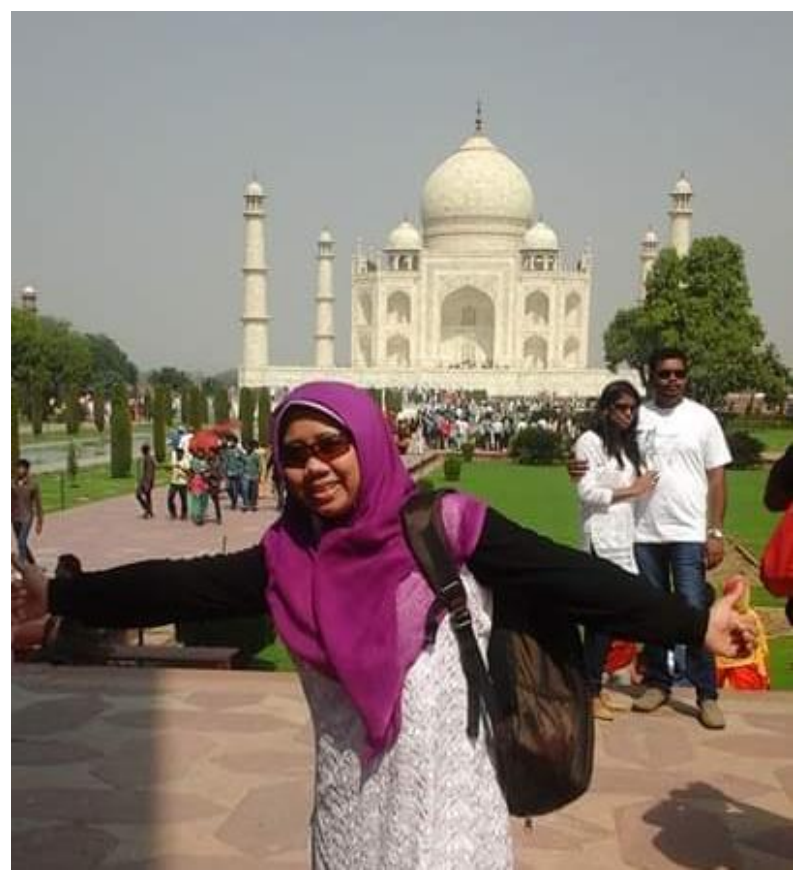

Gbr. Taj Mahal 
Setelah mengunjungi Taj Mahal, kami berkesempatan juga menyaksikan warisan dinasti Kerajaan Islam di Fatehpur Sikri, yang terletak di Uttar Pradesh, $30 \mathrm{~km}$ dari Taj Mahal. Fatehpur Sikri dulunya ibukota kebanggaan Kekaisaran Mughal pada abad ke 16. Fatehpur Sikri sekarang berdiri kosong sebagai kota hantu namun terjaga dengan baik. Tempat ini telah ditinggalkan oleh penghuninya karena pasokan air tidak mencukupi.

Fatehpur Sikri, sebuah kota kecil tak jauh dari Agra di India utara awalnya menyandang gelar yang gagah, yaitu "The City of Victory". Tapi mendadak secara misterius jatuh pamor, menjadi "A City an Emperor Forgot". Kisahnya memang sungguh menarik, terjadi saat dinasti Mughal mencapai puncak kejayaannya. Kekuasaan Akbar - sang Raja, membentang di India Utara, tak ada raja lain yang bisa menyainginya. Daerah kekuasaannya aman tenteram, dan gudang harta di istananya penuh sesak. Sayangnya sang Raja ini belum mempunyai putra mahkota dari sekian orang Ratunya..

Di sebuah tempat bernama Sikri, 37 kilometer dari Agra tinggal seorang Sufi suci bernama Sheikh Salim Chishti yang terkenal sakti. Sang Raja konon sampai sengaja berjalan kaki dari Agra ke Sikri untuk menemui dan mohon pertolongan Sufi Chishti atas masalah berat itu. Sang Sufi mengatakan bahwa Akbar akan mempunyai putra, malah sampai tiga orang. Benar saja tahun 1569 salah seorang ratu melahirkan Putra Mahkota, dan persis sesuai ramalan dua putra lainnya juga menyusul lahir. Sebagai rasa terima kasih dan syukur, tahun 1571 Akbar membangun istana besar di Sikri, dinamainya Fatehpur Sikri atau The City of Victory - sebagai simbol kemenangan berhasil menguasai wilayah Gujarat. 
Kota ini dibangun di sebuah bukit, terdiri dari dua komplek. Komplek yang pertama adalah bangunan istana serta taman. Di dalamnya selain kediaman raja, ada ruang audiensi, ruang harta, harem, barak penjaga, serta dapur. Komplek kedua untuk kediaman para Sufi suci dan Mesjid. Akbar menerapkan arsitektur dengan gaya campuran elemen Islam dengan Hindu, sehingga unik sekali. Arsitektur Islami yang bersumber dari Afganistan dan Persia ditandai dengan ornamen-ornamen di atas motif-motif geometrik yang cantik. Sedangkan pengaruh Hindu dan Buddha tampak dari kayanya warna kemerah-merahan. Memang gaya Akbar ini didominasi pemakaian red-sandstone. Gaya ini nantinya dikembangkan oleh cucunya: Shah Jahan, yang mengkombinasinya dengan pemakaian marmer untuk masterpiecenya yaitu Taj Mahal - salah satu dari tujuh keajaiban dunia. Secara bertahap pusat pemerintahan berpindah dari Agra ke kota baru ini, tetapi misteri terjadi 14 tahun kemudian. Tahun 1585 Akbar mendadak pindah dari Fatehpur Sikri, dan tidak pernah sekalipun menginjakkan kakinya lagi di kota yang belum lama dibangunnya itu.

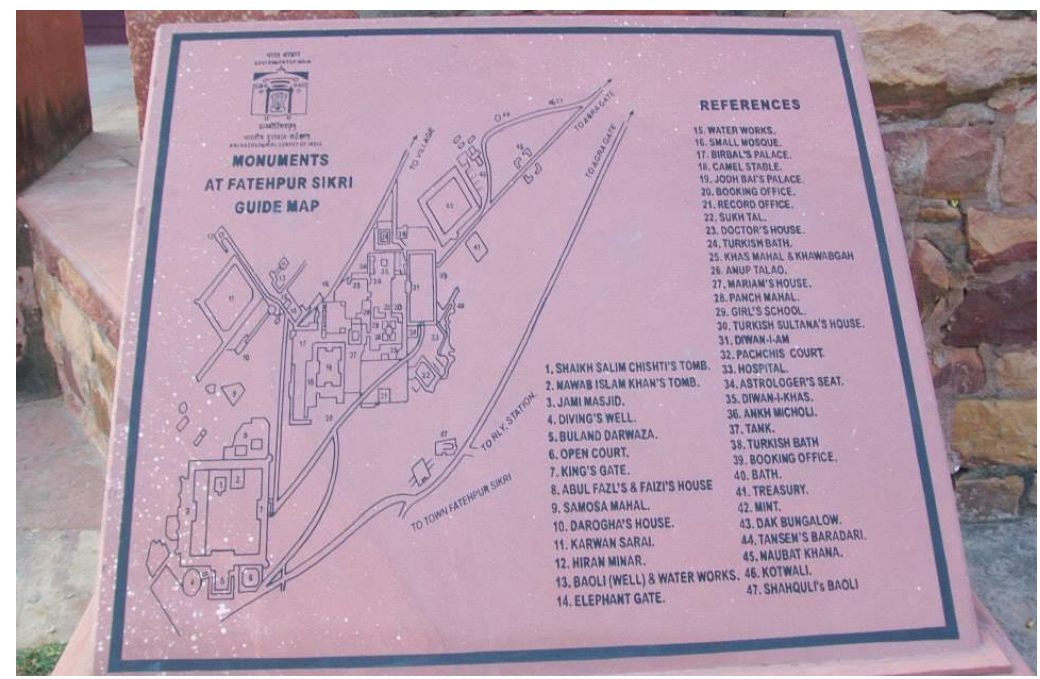

Gbr. Guide Map Fatehpur Sikri, di depan pintu masuk 


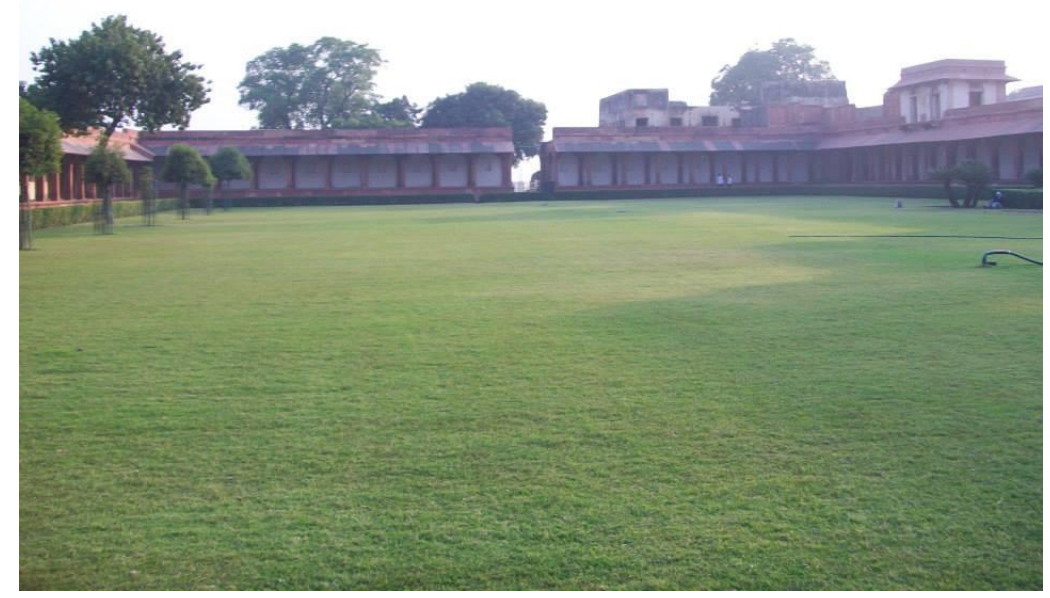

Gbr. Halaman luas di Fatehpur Sikri

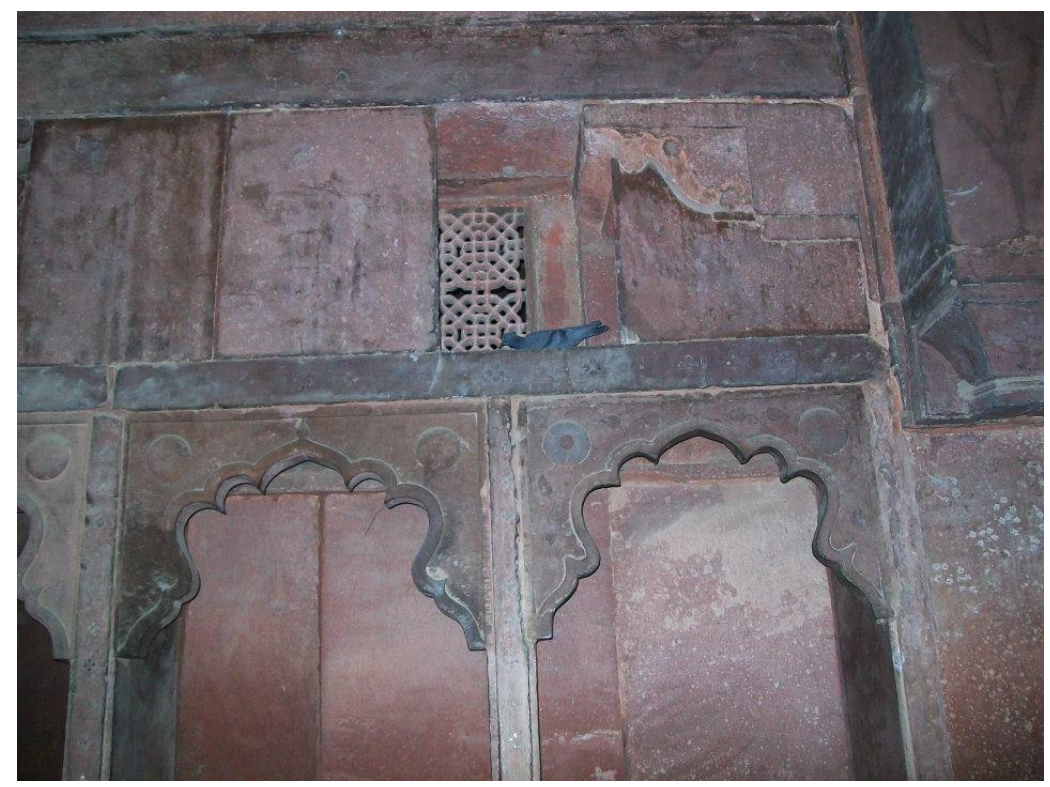

Gbr. Ornamen salah satu bangunan di Fatehpur Sikri 


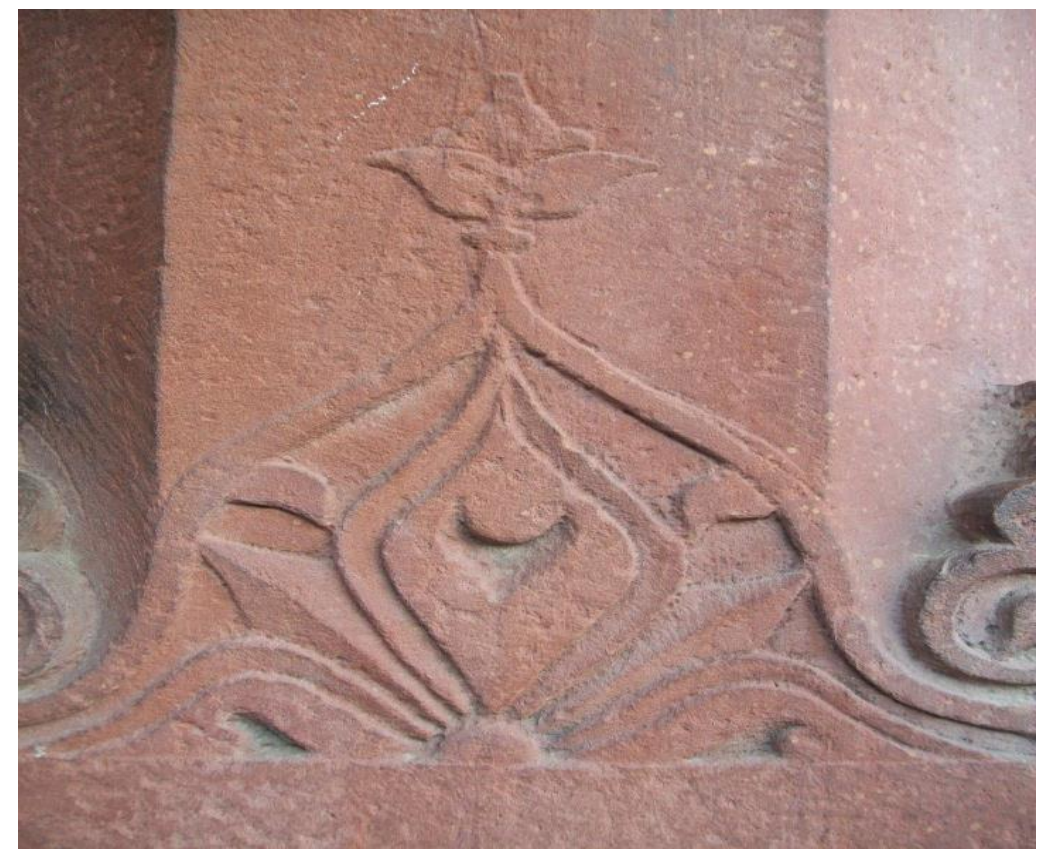

Gbr. Ornamen salah satu bangunan di Fatehpur Sikri

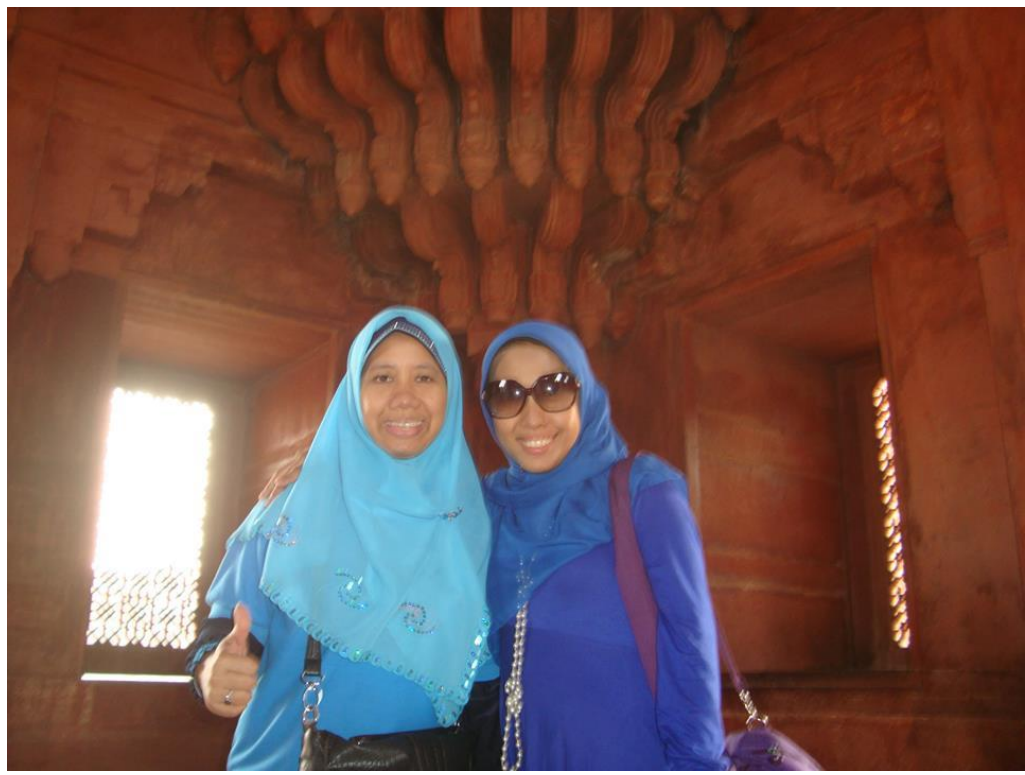

Gbr. Salah satu ornamen sudut bangunan di Fatehpur Sikri 
Setelah puas mengelilingi Fatehpur Sikri, sore harinya kami kembali. Karena tempat parkir bus jaraknya cukup jauh dan kami cukup lelah, akhirnya kami memutuskan untuk mencapai bus kami dengan naik tuk tuk, kendaraan tradisional khas India, mirip bajaj, namun agak lebih besar. Perjalanan kami berkendara dengan tuk tuk sangat seru dan tak akan pernah terlupakan. Begitu pula perjalanan kami ke beberapa tempat bersejarah di India merupakan pengalaman berharga bagi kami karena akan membuat kami lebih mencintai sejarah dan budaya manusia dari negara mana pun, apalagi sejarah dan budaya bangsa sendiri. (NMK)

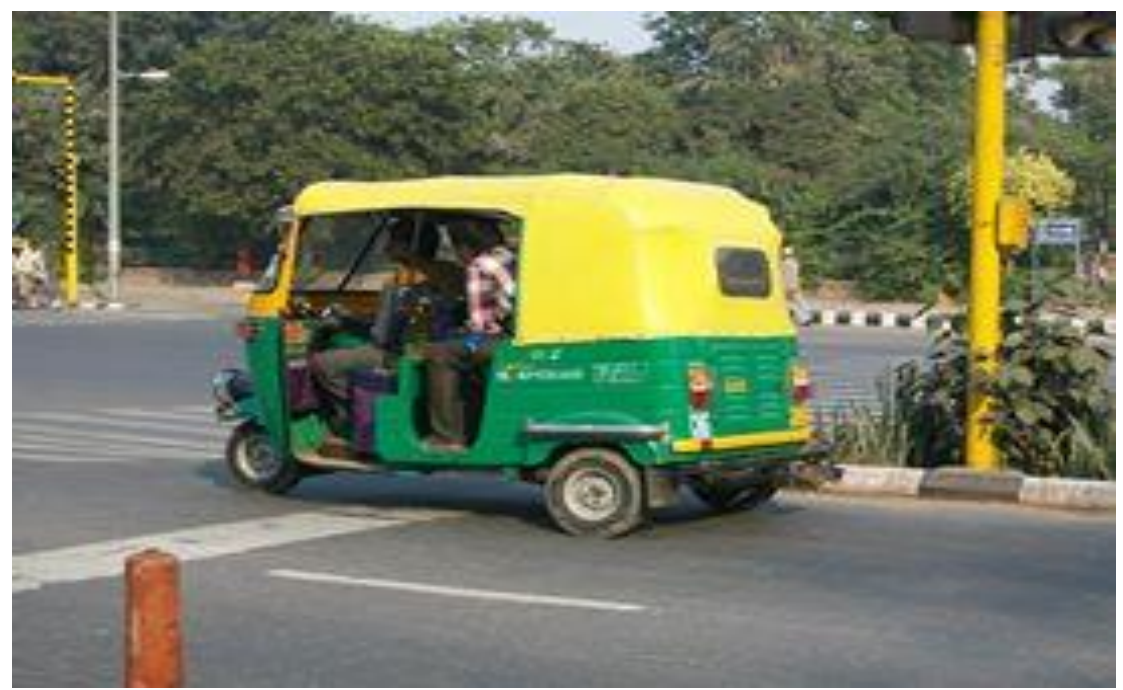

Gbr. Tuk tuk 


\section{DAFTAR PUSTAKA}

Agung, Lilik. 2007. Human Capital Competencies. Jakarta: Elex Media Komputindo

Al Maraghi, Ahmad Musthafa, 1993. Tafsir Al Maraghi. Penerjemah Bahrun Abubakar. Semarang: PT Karya Toha Putra

Alwi, Hasan, 2007. Kamus Besar Bahasa Indonesia Edisi Ketiga. Jakarta: Balai Pustaka

Badan Litbang dan Diklat Kementerian Agama RI. 2019. Moderasi Beragama. Jakarta: Badan Litbang dan Diklat Kementerian Agama RI

Barthos, Basyir, Drs. 2001. Manajemen Sumber Daya Manusia, Cetakan Keenam, Jakarta: Bumi Aksara

Boeree, C. George, Dr. General Psychology, Primasophie. Jogjakarta. 2008

Brown, S, P., Jones, E., \& Liegh Thomas, W., The Attenuating of Role Overload on Relationship Linking Self-Eficacy and Goal Level to Work Performance, Journal of Applied Psychology, 2005, Vol 90

Budiyanto, N. M. Profil Pegawai Negeri Sipil (PNS) Menuju Indonesia Baru. Artikel, (Palembang, Universitas Sriwijaya, 2006)

Chaer, Drs. Abdul. Linguistik Umum, , 2003, Jakarta, PT. Rineka Cipta

Chaplin, J. P. Kamus Lengkap Psikologi. Jakarta: PT RajaGrafindo Persada. 1999.

Chaplin, J.P. 2000. Dictionary of Psychology. New York: Sell Publishing Co. Inc

Covey, F. an Interview with Franklin Covey. (Diakses dari http://www.franklincovey.com. Tanggal 17 April 2005)

Dardjowidjojo, Soenjono. Psikolinguistik Pengantar Pemahaman Bahasa Manusia. 2005, Jakarta, Yayasan Obor Indonesia.

Gea, Antonius, dkk. 2002. Character Building I: Relasi dengan Diri Sendiri. Edisi Revisi. Jakarta: Gramedia Pustaka Utama.

Gie, T. L, Strategi Hidup Sukses, (Jogjakarta: Liberty, 1996) 
Gulo, W. Metodologi Penelitian, PT. Gramedia Widiasarana Indonesia. Jakarta. 2002

Hadipranata, F. A., Kiprah Ikhlas Amalkan Tugas (KIAT) Adalah Performansi Kerja Sejati, (Yogyakarta: Fakultas Psikologi Universitas Gadjah Mada, 1995), Buletin Psikologi Tahun 3, Nomor 2.

Hafbl, KH. Basyir Abu. 2007. 301Cahaya Ilahi Bekal hidup Sukses dan Mulia, Qultum Media, Depok:

Harefa, Andreas. (2009). Pengertian Karakter. Tersedia dalam http: //kabarmu.blogspot.402thcom/2009/05/ pengertian karakter.html. downloaded on April 16, 2011. International Journal of History education. Vol. XII, no. 2 (December 2011).

Hasman, Melvia A. "The Role of English in the 21st Century," English Teaching Forum, 38:2, January 2000 mengutip The Economist (New York: The Economist, Profile Books, 1996)

http://infopublik.id/kategori/sosial-budaya/395697/menag-bicaraekonomi-islam-dan-moderasi-beragama-di-uin-sumut

https://www.kliksaja.co/read/klik-news/sosial-budaya/prof-omanmoderasi-beragama-harus-jadi-perspektif-bersama-umat/

https://www.menpan.go.id/site/cerita-sukses-rb/5418-menuju-smartasn-2019

id.wikipedia.org/wiki/Sumber_daya_manusia, Juni 2011

Kanfer, F. H., \& Goldsein, A. P., Helping People Change: A Test Book of Methods, (New York: Pergamont Press, Inc, 1995)

Kartono, Kartini Dr. 2006. Pemimpin dan Kepemimpinan. PT. Raja Grafindo Persada, Jakarta,

Kepala Biro Kepegawaian Sekretariat Kementerian Agama, Arahan saat Rapat Koordinasi Perencanaan Program dan Anggaran tahun 2012, 27 Maret 2011 Denpasar

Keputusan Menteri Agama Nomor 345 Tanun 2004 tentang Organisasi dan Tata Kerja Balai Pendidikan dan Pelatihan Keagamaan;

Keputusan Mentri Agama Nomor 1 Tahun 2003 tentang Pedoman Pendidikan dan Pelatihan Pegawai Negeri Sipil di Lingkungan Departemen Agama; 
Kimble, Gregory A, et al. Principles of Psychology, sixth edition, John Wiley \& Sons, New York, Chichester, Brisbane, Toronto. Singapore. 1984

KMA No. 1 tahun 2003 tentang Pedoman Diklat PNS

Kridalaksana, Harimurti. 1983. Kamus Linguistik. Jakarta: Gramedia

Lubis, Ridwan. 2011. Presentation at The Limited Meeting of The Members of The Presidential Council for Interfaith Relations.

Macan, T. H. Time Management: Test of Process Model, Uournal of Applied Psychology, 1994), Vol.79, No.3

Manz, C. C., \& Sims, H. Positivisme, Jr., Self-Management as A Substitude Leadership: A Social Learning Theory Perspective, (New York: Mc graw Hill, 1995)

Margono, S. Drs. Metodologi Penelitian Pendidikan. Rineka Cipta. Jakarta. 2005

Mathis, Robert L, Jackson, John, H (2001), Manajemen Sumber Daya Manusia, Edisi I, Jakarta: Salemba Empat

Misrawi, Zuhairi. 2010. Hadratussyaikh Hasyim Asy'ari Moderasi, Keutamaan, dan Kebangsaan. Jakarta: PT Kompas Media Nusantara

Myers, M. S., Every Employee A Manager, (New York: McGraw Hill, 1991)

Novia, Windy. 2009. Kamus Ilmiah Populer. Jakarta: Wipress

Nurmaida, 2016. Membangun Integritas Guru dalam melaksanakan Pembelajaran, https://www.academia.edu/36161930/Membangun Integritas Guru Dalam Melaksanakan Pembelajaran diakses tanggal 17 Juni 2019

Pedler, M., \& Boydell, t., Managing Your Self, (London: Harper Collins Publisher. 1995)

Peraturan Bersama Kepala Lembaga Administrasi Negara dan Kepala Badan Kepegawaian Negara Nomor 1 dan 2 Tahun 2010 tentang Petunjuk Pelaksanaan Jabatan Fungsional Widyaiswara dan Angka Kreditnya;

Peraturan Kepala Lembaga Administrasi Negara Nomor 25 tahun 2015 Tentang Pedoman Akreditasi Lembaga Pendidikan dan Pelatihan Pemerintah 
Peraturan MENPAN Nomor 14 Tahun 2009 tentang Jabatan Fungsional Widyaiswara dan Angka Kreditnya;

Peraturan Menteri Agama Nomor 3 Tanun 2006 tentang Organisasi dan Tata Kerja Kementerian Agama (disempurnakan)

Peraturan Menteri Agama Republik Indonesia Nomor 10 Tahun 2010 tentang Organisasi dan Tata Kerja Kementerian Agama

Peraturan Pemerintah Nomor 101 Tahun 2000 tentang Pendidikan dan Pelatihan Pegawai Negeri Sipil;

Peraturan Pemerintah Nomor 16 Tahun 1994 tentang Jabatan Fungsional Pegawai Negeri Sipil;

Peraturan Pemerintah Nomor 42 Tahun 2004 tentang Kode etik PNS

Rachman, Eileen. "Meraba Integritas, Dapatkah?" KOMPAS, Sabtu, 27 Mei, 2006, Hlm. 43, kolom 1-5.

Rakhmat, J.. Psikologi Komunikasi. Remaja Karya CV, Bandung. 1982

Rivai, Veithzal, Prof. Dr., M. B. A, Manajemen Sumber Daya Manusia untuk Perusahaan Dari Teori ke Praktik, PT Raja Grafindo Persada, Jakarta. 2005

Robbins, Stephen P. Perilaku Organisasi, Konsep, Kontroversi dan Aplikasi. Alih Bahasa: Hadyana Pujaatmaka. Edisi Keenam. PT. Bhuana Inti Populer, Jakarta. 1996

Sekretaris Jenderal Kementerian Agama, Arahan dalam Muatan Teknis Substansi Lembaga Diklatpim III Angkatan XXXIII, 20 Juni 2011, Jakarta

Simamora, Henry. Manajemen Sumberdaya Manusia. Yogyakarta: Bagian Penerbitan STIE YKPN. 1995

Simbolon, P. Upaya Meningkatkan Kinerja PNS. (Artikel, 2009)

Soekadji.. S., Modifikasi Perilaku; Penerapan Sehari-hari dan Penerapan Profesional, (Jogjakarta: Liberty, 1993)

Soetjipto, 2000. Profesi Keguruan. Jakarta: Rineka Cipta

Sugiyono. Metode Penelitian Pendidikan: Pendekatan Kuantitatif, Kualitatif, dan $R \& D$. Bandung: Alfabeta, Cet. Ke-1. 2008. 
Surat Kepala Badan Litbang dan Diklat Kementerian Agama No. Set.BD/3/KP.03/2396/2013 tanggal 03 Oktober 2013 tentang Pemanggilan Peserta Short Course.

The Little Life Gallery Blog http://thelittlelifegallery.blogspot.com/2009/07/

Undang-undang Nomor 5 Tahun 2014 tentang Aparatur Sipil Negara

Undang-undang Nomor 8 Tahun 1974 sebagaimana telah diubah dengan Undang-undang Nomor 43 Tahun 1999 Tentang Pokok-Pokok Kepegawaian

Undang-undang Nomor 8 Tahun 1974 tentang Pokok-pokok Kepegawaian yang telah diubah dengan Undang-undang Nomor 43 Thun 1999;

Wahyudi, Dwi. 2016. Bedah Kamus Kompetensi Kementerian Keuangan https://www.djkn.kemenkeu.go.id/artikel/baca/9601/BEDAHKAMUS-KOMPETENSI-KEMENTERIAN-KEUANGAN.html diakses tanggal 17 Juni 2019

Wikipedia id.wikipedia.org/wiki/Sumber_daya_manusia, Juni 2011

Wikipedia www.wikiwedia.co.id diakses tanggal 20 Juni 2019 


\section{BIODATA PENULIS}

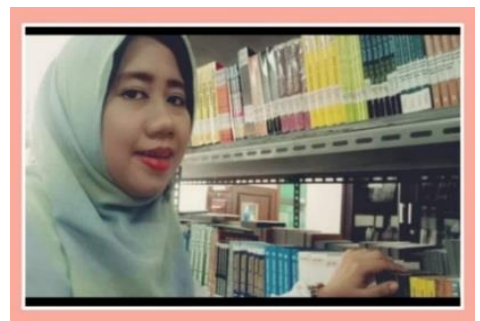

Neneng Maria Kiptyah, lahir di Jakarta pada tanggal 14 Agustus 1977, anak pertama dari lima bersaudara pasangan M. Suri HS. dan Suhana. Menyelesaikan pendidikan di Madrasah Ibtidaiyah Darul Ulum Jakarta Barat (1989), Madrasah Tsanawiyah Jamiat Kheir Tanah Abang Jakarta Pusat (1992), Madrasah Aliyah Jamiat Kheir Tanah Abang Jakarta Pusat (1995), Sarjana Pendidikan Bahasa Inggris (2000) di Univeritas Negeri Jakarta dan Magister Pendidikan Bahasa (2009) pada Program Pascasarjana di Universitas Negeri Jakarta. Kini sedang berusaha menamatkan pendidikan Strata 3 di PTIQ Jakarta Konsentrasi Pendidikan Berbasis Al Quran. Pengalaman mengikuti Shortcourse di NUEPA New Delhi India tahun 2013. Sejak tahun 2000 mengajar di Akademi Farmasi Hang Tuah AL hingga sekarang. Pengalaman mengajar di Nurul Fikri English Course (NEC) (2001 - 2005), serta menyusun buku kursus untuk anak bersama tim dari National English Centre Jakarta Timur (2000-2001). Pekerjaan yang sekarang digeluti selain dosen adalah Widyaiswara/Trainer pada Pusdiklat Tenaga Administrasi Badan Litbang dan Diklat Kementerian Agama, serta salah seorang pengelola majalah "Suara Diklat" dan OJS "Jurnal Kompetensi." Mata diklat yang diampu adalah mata diklat yang berkaitan dengan Capacity Building, Pengembangan Diri, Kecerdasan Spiritual, Kecerdasan Emosional, Membangun Tim Efektif, Jejaring Kerja, Koordinasi Kolaborasi. Menikah dengan Dodi Firmansyah, seorang guru bahasa Inggris, pada tanggal 16 Februari 2003, dan dikaruniai dua orang putri dan seorang putra: Hanadia Syahidah Firmansyah, Haniyah Syahidah 
Firmansyah dan Hannan Syahid Firmansyah. Domisili di Jakarta tepatnya di Jl. Angsana No. 13 Kebun Jeruk Jakarta Barat. Untuk korespondensi dapat menghubungi alamat email: mariakiptyah@gmail.com sedangkan nomor hp yang dapat dihubungi 081311302679 dan 081519291818.

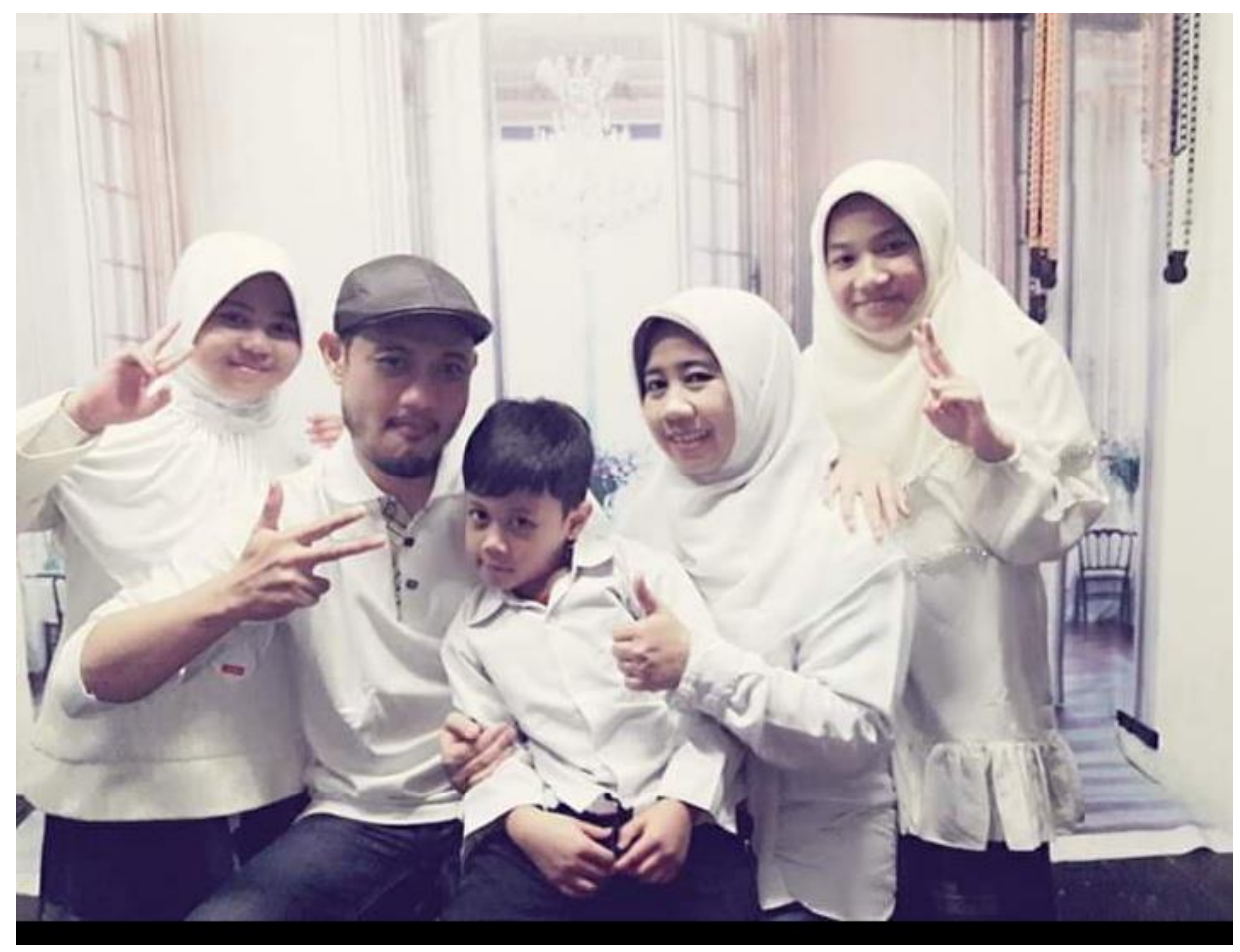

